CLÁUDIA MARIA FURLAN

\title{
EFEITOS DA POLUIÇÃO AÉREA DE CUBATÃO SOBRE O CONTEÚDO DE NITROGÊNIO, FIBRAS, LIGNINAS E SUBSTÂNCIAS FENÓLICAS FOLIARES E ATIVIDADE HERBIVÓRICA EM Tibouchina pulchra Cogn..
}

Dissertação apresentada ao Departamento de Ecologia Geral do Instituto de Biociências da Universidade de São Paulo, como parte dos requisitos para a obtenção do título de Mestre em Ecologia.

Orientador: Prof. Dr. Antonio Salatino

São Paulo

1998 
Às minhas grandes amigas: minha mãe, Adelaide, e minha irmã, Silvia. 


\section{AGRADECIMENTOS}

À todas as pessoas que colaboraram direta ou indiretamente com a elaboração deste trabalho, em especial:

Ao Prof. Dr. Antonio Salatino, do Departamento de Botânica do Instituto de Biociências da USP, pela orientação, ensinamentos, colaboração e principalmente bom humor e paciência durante $o$ desenvolvimento deste trabalho;

À Marisa Domingos, PqC da Seção de Ecologia do Instituto de Botânica e primeira a acreditar no meu futuro com a ciência, pela coorientação e especialmente pela demonstração de como ter bom senso e paciência na hora certa;

À Mirian Cilene Spaziani Rinaldi, responsável pelo laboratório da Seção de Ecologia do Instituto de Botânica, pela companhia e ajuda durante às análises laboratoriais e por todas as explicações químicas que prestativamente sempre forneceu;

À Amarilis, Anna, Irene, S. Joaquim, Neuzete e Marli, funcionários e estagiários da Seção de Ecologia do Instituto de Botânica, pelo revezamento na companhia durante às coletas e trabalhos de campo, tornando a minha obrigação uma diversão;

À Gabriele e Andreas Klumpp, pelos incentivos não somente durante o convênio Brasil/Alemanha, mas também pelo apoio vindo de longe via correio ou e-mail;

Aos funcionários e estagiários da Seção de Ecologia: Amarilis, Anna, Irene, S. Joaquim, Luiz Mauro, Liliam, Márcia Dias, Márcia Nichii, Márcia Lopes, Marisa, Marli, Mirian, Neuzete, Patrícia, Regina, Sônia, Valdenice, Yara e Yuri, pela companhia e especialmente pela descontração durante as maravilhosas horas do cafezinho e os incontáveis festejos;

Ao Yuri e Sidney, pelo empréstimo e pelas dicas de utilização do scanner, e ao Zé pelo empréstimo da impressora;

À Seção de Ecologia do Instituto de Botânica da qual pude usufruir espaço físico, viagens de campo e da amizade e carinho de todos os funcionários e estagiários; 
À Seção de Bioquímica e Fisiologia Vegetal do Instituto de Botânica pela possibilidade de utilização do equipamento de análise de área foliar;

À FAPESP, pelo financiamento do projeto;

Aos amigos de gandaia, pela amizade. A eles devo meu bom humor, tranqüilidade e lucidez;

À minha família: minha mãe pela paciência e companhia, e minha irmã pela amizade e incentivo. 


\section{ÍNDICE}

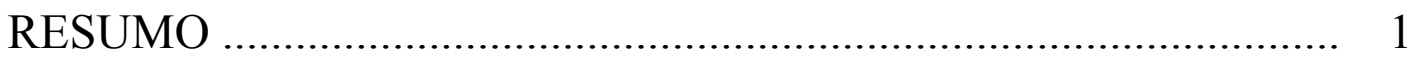

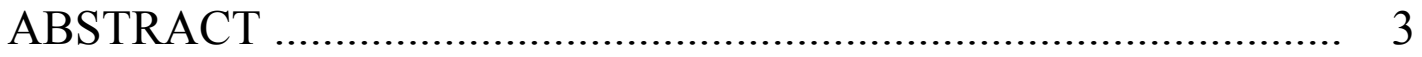

I. INTRODUÇÃO ................................................................ 5

1. Aspectos Gerais ……........................................................ 5

2. Efeitos de poluentes sobre as planas ..................................... 8

3. Poluição em Cubatão .......................................................... 14

4. Objetivos ……............................................................... 16

II. MATERIAL E MÉTODOS _.................................................. 18

1. Caracterização da área de estudo ........................................ 18

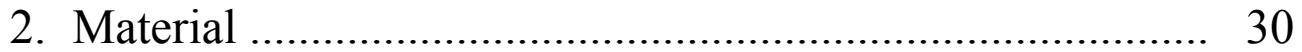

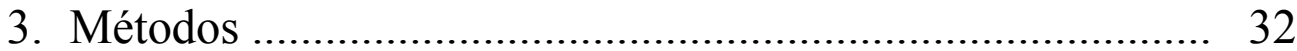

3.1. Nitrogênio Orgânico ……….................................. 32

3.2. Compostos Fenólicos Totais …….......................... 32

3.3. Taninos Totais ..................................................... 33

3.4. Fibras e Ligninas ............................................... 34

3.5. Área Foliar ..................................................... 35

4. Análises Estatísticas ..................................................... 37

III. RESULTADOS E DISCUSSÃO _....................................... 39

1. Efeito da poluição nos parâmetros estudados ................... 39

1.1. Nitrogênio Orgânico ................................................ 39

1.2. Compostos Fenólicos Totais.................................... 45

1.3. Taninos Totais ................................................... 52

1.4. Fibras e Ligninas .................................................. 58

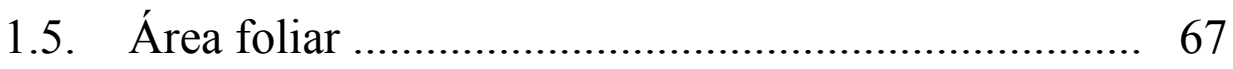

2. Efeitos das alterações metabólicas na herbivoria ............... 80

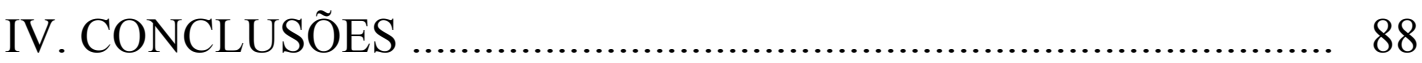

V. REFERÊNCIAS BIBLIOGRÁFICAS _..................................... 90 


\section{RESUMO}

O crescente processo de industrialização na região de Cubatão, São Paulo, e as resultantes emissões de poluição vêm há tempos afetando a vegetação da Serra do Mar ao seu redor, um remanescente da Mata Atlântica. Para avaliar os efeitos da poluição aérea nos teores de alguns metabólitos, de forma a relacioná-los com a intensidade de herbivoria foliar em Tibouchina pulchra Cogn. (Melastomataceae), espécie predominante na região, foram realizadas análises de nitrogênio, compostos fenólicos totais, taninos totais, fibras, ligninas, área foliar total e área foliar perdida por herbivoria. Folhas maduras de cinco indivíduos adultos de Tibouchina pulchra foram coletadas nos meses de janeiro, fevereiro, junho e julho de 1996 e 1997, em três áreas amostrais na região de Cubatão e Serra do Mar: Vale do Rio Pilões (RP), próxima à captação de água da SABESP, com pouca influência da poluição aérea de Cubatão, considerada como área de referência neste trabalho; Caminho do Mar (CM), área que acompanha a antiga estrada de ligação São Paulo-Santos e com influência da poluição emitida por indústrias petroquímicas localizadas no final dessa rodovia; e Vale do Rio Mogi (VM), área fortemente afetada pela poluição devido à proximidade a indústrias dos ramos siderúrgico, químico, de fertilizantes e de cerâmica.

Verificou-se que nas áreas poluídas do Vale do Rio Mogi e do Caminho do Mar, quando comparadas ao Vale do Rio Pilões, foram maiores os teores foliares de nitrogênio $(19,86 \mathrm{mg} / \mathrm{g} \mathrm{RP} ; 23,16 \mathrm{mg} / \mathrm{g}$ $\mathrm{CM} ; 25,14 \mathrm{mg} / \mathrm{g} \mathrm{VM})$, fibras (36,03\% RP; 45,91\% CM; 48,5\% VM) e ligninas $(9,98 \% \mathrm{RP} ; 12,98 \% \mathrm{CM} ; 8 \% \mathrm{VM})$, mas foram menores as concentrações foliares de compostos fenólicos (4,65\% RP; 1,66\% $\mathrm{CM} ; 2,15 \% \mathrm{VM})$ e taninos ( $0,84 \% \mathrm{RP} ; 0,26 \% \mathrm{CM} ; 0,50 \% \mathrm{VM})$. Não se observou diferenças nas áreas foliares totais, mas houve uma maior porcentagem de área foliar perdida por herbivoria nos indivíduos das áreas poluídas $(0,40 \% \mathrm{RP} ; 0,90 \% \mathrm{CM} ; 3,46 \% \mathrm{VM})$, assim como foi observada uma maior porcentagem de galhas na superfície adaxial das folhas dos indivíduos do Vale do Mogi (4,25\% RP; 1,25\% CM; 8,42\% 
VM). Foram pequenas as diferenças entre os valores encontrados para verão e inverno para todos os parâmetros estudados. Os resultados indicam que há um efeito da poluição atmosférica nos parâmetros estudados e que as alterações nesses compostos, relacionados com os sistemas de defesa da planta contra o ataque de herbívoros, estejam influenciando na quantidade de área foliar perdida por herbivoria.

Para explicar a intensidade de herbivoria foliar sofrida pelos indivíduos de Tibouchina pulchra, foram realizadas análises de regressão que revelaram três modelos diferentes, um para cada área amostral. $\mathrm{Na}$ área de referência do Vale do Rio Pilões, o modelo selecionado relaciona a intensidade de herbivoria foliar com a quantidade de taninos, explicando $11 \%$ da variabilidade da porcentagem de herbivoria, podendo-se dizer que há herbivoria tanto mais intensa quanto menor a quantidade de taninos foliares. Para o Caminho do Mar, o fator ligninas foi o que melhor explicou a quantidade de herbivoria: em aproximadamente $25 \%$ dos casos, a intensidade de herbivoria foi tanto maior quanto menor a quantidade de ligninas. No Vale do Rio Mogi, aproximadamente $8 \%$ da intensidade de herbivoria pode ser explicada pela quantidade de compostos fenólicos, também através de correlação negativa. Os coeficientes de regressão para os parâmetros selecionados nos três modelos são significantes. Uma vez que os coeficientes de explicação são baixos, sugere-se que outros fatores, não avaliados neste estudo, estejam interferindo na intensidade de herbivoria foliar sofrida pelos indivíduos das três áreas. 


\begin{abstract}
The vegetation of the Atlantic Forest on Serra do Mar near the industrial complex of Cubatão (state of São Paulo, Brazil) has been subject of severe damage caused by massive emissions of pollutants, as a result of the progressive industrialization in the area. The amounts of nitrogen, total soluble phenols, total tannins, fibers and lignins, as well as leaf area, leaf area damage by herbivory and percentage of galls, were measured for leaves of Tibouchina pulchra Cogn. (Melastomataceae), a species resistant to air pollution and widespread in the region. The purpose of the investigation was to evaluate the effects of air pollution on the content of some classes of secondary metabolites and the possible consequences on the intensity of foliar herbivory.

Fully expanded leaves of five individuals were collected for analysis in January, February, June and July 1996 and 1997, at three sites of Cubatão and Serra do Mar, each area presenting distinct pollution loads: the Pilões Valley (RP), near to SABESP station, characterized by a virtually undamaged vegetation and taken as a reference area; the Caminho do Mar (CM), along the old road connecting the cities of São Paulo and Santos, influenced mainly by the pollution emitted by petrochemical industries at the foot of this road; Mogi Valley (VM), close to the core region of the industrial complex, influenced mainly by pollution emitted fertilizer and chemical industries, steel production and cement factories.
\end{abstract}

Relative to Pilões Valley, the individuals growing in the Caminho do Mar and Mogi Valley areas presented higher amounts of foliar nitrogen (on average 19,86 mg/g RP, 23,16 mg/g CM and 25,14 $\mathrm{mg} / \mathrm{g} \mathrm{VM}$ ), fibers (36\% RP, 46\% CM and 49\% VM) and lignins (10\% RP, $13 \% \mathrm{CM}$ and $8 \% \mathrm{VM}$ ) and lower amounts of total soluble phenols (5\% RP, $1,7 \% \mathrm{CM}$, and 2,2\% VM) and tannins ( $0,84 \% \mathrm{RP}$, $0,26 \% \mathrm{CM}$ and $0,5 \% \mathrm{VM})$. The total leaf area found was not significantly different from one area to another, but differences were 
observed relative to the areas consumed by herbivory: they were larger at Mogi Valley and Caminho do Mar than at Pilões Valley $(0,4 \% \mathrm{RP}, 0,9 \% \mathrm{CM}$ and 3,5\% VM). The percentage of galls was highest at Mogi Valley and lowest at Caminho do Mar, Pilões Valley presenting an intermediate value $(4,25 \% \mathrm{RP}, 1,25 \% \mathrm{CM}$ and 8,42 $\mathrm{VM})$. For all parameters measured, the differences between summer and winter were not significant. The results show that the air pollution released by the industrial complex of Cubatão affects the foliar content of nitrogen and secondary metabolites and that such alterations affect the intensity of herbivory.

Regression analysis were carried out relative to the three selected areas of Cubatão, in order to look for an explanation for the leaf loss by herbivory. The model of regression selected the variable tannin content as the most important to explain the leaf area at Pilões Valley, $11 \%$ of the herbivory being accounted for by that parameter. In individuals from Pilões Valley, the intensity of foliar herbivory correlates negatively with tannin content. The lignins content accounts for $25 \%$ of the herbivory intensity at Caminho do Mar, a negative correlation between the latter parameter and lignins content being noticed. Approximately $8 \%$ of the herbivory intensity is accounted for by the content of total soluble phenols at Mogi Valley, again through a negative correlation. The regression coefficients found were significant, notwithstanding their small values. The results suggest that other factors, not investigated in the present work, also influence the intensity of foliar herbivory. 


\section{INTRODUÇÃO}

\section{ASPECTOS GERAIS}

A partir da Revolução Industrial, no início do século XIX, teve início nos primeiros países a passarem pela fase de industrialização, como os da Europa e América do Norte, a liberação de resíduos gerados a partir de processos industriais. Estes foram se acumulando na atmosfera, assim como nos solos e cursos d'água, surgindo no ambiente um novo fator condicionante da vida (Freedman, 1989). Atualmente, nas grandes cidades, tanto em países industrializados como nos em desenvolvimento, as atividades industriais, o tráfego intenso de veículos automotores, a grande produção e acúmulo de lixo e os problemas com saneamento e redes de esgotos, contribuem para o constante acúmulo de poluentes no ambiente.

A emissão de substâncias na atmosfera em forma de gases ou material particulado, aerossóis, e outras pode ser tanto de origem natural como antrópica. Entretanto, a quantidade de compostos lançados na atmosfera via ação antrópica supera em muito a quantidade emitida durante processos naturais, de forma que são acumulados na atmosfera e atingem concentrações muitas vezes tóxicas (Freedman, 1989). Entende-se por poluente atmosférico, segundo definido no "Clean Air Act" de 1981, qualquer agente poluidor ou combinação de vários agentes, incluindo qualquer substância física, química, biológica ou radioativa, a qual é emitida e acumulada na atmosfera de forma a se tornar tóxica aos organismos (Hughes, 1988).

Os poluentes atmosféricos podem afetar propriedades atmosféricas, como redução de visibilidade, alteração na radiação solar, ou a distribuição de temperatura e ventos (Schlesinger, 1991; Miguel, 1992), assim como podem levar à corrosão de edificações ou equipamentos (Flores, 1987). Podem ainda afetar os seres vivos, 
promovendo a degradação do ambiente por inteiro ao redor dos grandes centros urbanos industriais.

As substâncias usualmente consideradas como poluentes atmosféricos podem ser agrupados nas categorias: compostos de enxofre $\left(\mathrm{SO}_{2}, \mathrm{SO}_{3}, \mathrm{H}_{2} \mathrm{~S}\right.$, sulfatos), compostos de nitrogênio ( $\mathrm{NO}, \mathrm{NO}_{2}, \mathrm{NH}_{3}, \mathrm{HNO}_{3}$, nitratos), compostos orgânicos de carbono (hidrocarbonetos, álcoois, aldeídos, cetonas, ácidos orgânicos), monóxido de carbono e dióxido de carbono, compostos halogenados ( $\mathrm{HCl}, \mathrm{HF}$, cloretos, fluoretos) e material particulado (mistura de compostos no estado sólido ou líquido). Entretanto, a determinação da qualidade do ar se faz através da escolha de alguns tipos de poluentes que servem como indicadores, definidos em função da sua importância, maior freqüência de ocorrência e aos efeitos adversos que causam aos ambientes (CETESB, 1997). A tabela 1 lista as principais fontes e processos de poluição e quais os principais poluentes atmosféricos emitidos por eles.

De forma geral, os poluentes que podem servir como indicadores da qualidade do ar mais freqüentemente encontrados na atmosfera são: dióxido de enxofre $\left(\mathrm{SO}_{2}\right)$, emitido principalmente por indústrias químicas, petroquímicas, de celulose e através da queima de combustíveis; óxidos de nitrogênio $\left(\mathrm{NO}_{\mathrm{x}}\right)$, produzido por indústrias químicas e de fertilizantes e também pela queima de combustíveis; hidrocarbonetos $\left(\mathrm{C}_{\mathrm{m}} \mathrm{H}_{\mathrm{n}}\right)$ e outros compostos voláteis orgânicos, produzidos pela combustão de motores e por indústrias petroquímicas; fluoretos (HF), emitidos principalmente por indústrias de fertilizantes fosfatados, siderúrgicas e indústrias de cerâmica; poluentes secundários, como ozônio $\left(\mathrm{O}_{3}\right)$ e nitrato de peroxiacetila (PAN), formados fotoquimicamente nas camadas superiores da atmosfera em condições meteorológicas específicas, através da reação de hidrocarbonetos e principalmente dióxido de nitrogênio $\left(\mathrm{NO}_{2}\right)$; e material particulado, ou seja, todas as partículas em suspensão na atmosfera, com diâmetro de corte de $30 \mu \mathrm{m}$, produzidas pelas diversas atividades industriais citadas 
anteriormente (Freedman, 1989; Alonso \& Godinho, 1992; Miguel, 1992). 
Tab. 1 - Principais fontes e processos de poluição do ar e os principais poluentes emitidos por eles (baseado em CETESB, 1997).

FONTES POLUENTES

\section{FONTES ESTACIONÁRIAS}

Combustão

Processo Industrial

Queima de Resíduo Sólido

FONTES MÓVEIS

Veículos gasolina/diesel

Álcool, aviões, motocicletas, etc

FONTES NATURAIS

REAÇÕES QUÍMICAS NA ATMOSFERA
Material particulado;

$\mathrm{SO}_{2}, \mathrm{SO}_{3}, \mathrm{CO}, \mathrm{NO}_{\mathrm{x}}$ e hidrocarbonetos

Material particulado: fumos, poeiras, névoas

Gases - $\mathrm{SO}_{2}, \mathrm{SO}_{3}, \mathrm{HCl}$, hidrocarbonetos, $\mathrm{HF}, \mathrm{H}_{2} \mathrm{~S}$, mercaptanas, $\mathrm{NO}_{\mathrm{x}}$

Material particulado;

Gases - $\mathrm{SO}_{2}, \mathrm{SO}_{3}, \mathrm{HCl}, \mathrm{NO}_{\mathrm{x}}$

Material particulado, monóxido de carbono, óxidos de enxofre, óxidos de nitrogênio, hidrocarbonetos, aldeídos, ácidos orgânicos

Material particulado - poeiras;

Gases - $\mathrm{SO}_{2}, \mathrm{H}_{2} \mathrm{~S}, \mathrm{CO}, \mathrm{NO}, \mathrm{NO}_{2}$, hidrocarbonetos

Poluentes secundários $-\mathrm{O}_{3}$, aldeídos, ácidos orgânicos, nitratos orgânicos, aerossol fotoquímico, etc

Os países da Europa e América do Norte foram os primeiros a sentir os efeitos das alterações ambientais, uma vez que começaram seu desenvolvimento industrial muito antes que os países reconhecidos hoje como subdesenvolvidos ou em desenvolvimento. Tais países, considerados desenvolvidos, vêm há algum tempo tentando adequar medidas de proteção ambiental, visando não apenas reduzir o impacto da poluição, mas também mapeá-lo e controlá-lo. Dessa forma, sofisticados instrumentos de identificação e quantificação de poluentes foram sendo criados e aperfeiçoados, porém seus resultados fornecem uma idéia momentânea e pontual, ou seja apenas uma medida da concentração de um poluente, em tempo e local determinados, não fornecendo informações sobre efeitos cumulativos ou até mesmo efeitos sinérgicos, 
ou seja, da combinação de diferentes poluentes, sobre os organismos vivos (Flores, 1987; Arndt \& Schweizer, 1991).

\section{EFEITOS DE POLUENTES SOBRE PLANTAS}

Data de 1849 o primeiro relato do efeito de um poluente sobre organismos, quando o biólogo alemão Stöckhardt observou uma relação entre o conteúdo de enxofre de plantas que cresciam próximas a uma indústria de fundição de prata e a quantidade de necroses foliares que apresentavam (Dässler \& Börtitz, 1988).

Teoricamente, todos os organismos vivos possuem a habilidade de modificar suas funções vitais frente a mudanças no ambiente em que vivem. Algumas vezes, essa característica de determinados organismos responderem a estímulos externos modificando suas funções vitais a fim de restabelecerem o equilíbrio inicial pode ser facilmente determinada e, assim, utilizada como critério ou indicador de mudanças ambientais de origem natural ou antrópica, entre elas a presença de poluentes (Arndt \& Schweizer, 1991; Flores, 1987). Tais organismos ou grupo de organismos são denominados bioindicadores, e a sua utilização em programas de avaliação de impactos ambientais constitui a técnica do biomonitoramento (Ellenberg, 1991). Segundo Guderian e colaboradores (1985), a resposta dos bioindicadores pode ajudar a identificar problemas ecológicos, documentar mudanças e tendências na qualidade dos ecossistemas florestais e prever efeitos em habitats ainda preservados, tendo assim grande aplicabilidade em estudos de impactos ambientais.

Os primeiros trabalhos realizados para investigação dos efeitos da poluição atmosférica sobre plantas eram principalmente estudos de campo, como o realizado por Stöckhardt em 1849, com observações de que plantas que cresciam em regiões próximas a indústrias geralmente apresentavam crescimento alterado ou folhas danificadas, quando comparadas com plantas de regiões mais distantes. A preocupação com essa fitotoxicidade se consolidou por volta de 1940, quando grande parte das florestas de coníferas da Europa e América do Norte começaram a apresentar alta taxa de mortalidade de suas árvores. Várias espécies 
vegetais foram estudadas e passaram a ser utilizadas como bioindicadores específicos, como Nicotiana tabacum cv. Bel W3 (indicadora de ozônio), Urtica urens (indicadora de ozônio e PAN), híbridos de Petunia (indicadores de hidrocarbonetos e PAN), híbridos de Gladiolus (indicadores de fluoretos), Lolium multiflorum (indicadora de metais pesados), Mangifera indica (indicadora de dióxido de enxofre) e Zea mays (indicadora de ozônio, dióxido de enxofre e fluoretos) (Arndt \& Schweizer 1991; Klumpp et al. 1994a).

A partir dessas primeiras observações, foram se consolidando os trabalhos com câmaras de fumigação, onde era possível expor determinada espécie vegetal a doses conhecidas do poluente em estudo, identificando-se assim o efeito de cada poluente e sua concentração na fisiologia e bioquímica da planta. Os vários trabalhos de biomonitoramento, tanto estudos de campo como em câmaras de fumigação, levaram à padronização de metodologias e também à criação de guias de identificação de tipos de necroses apresentadas pela planta e o poluente causador (Flores, 1987; Arndt \& Schweizer, 1991; Ellenberg, 1991; Mazzoni-Viveiros, 1996).

O biomonitoramento da poluição atmosférica passou então a ser um método alternativo de mapeamento e controle da poluição, sendo realizado basicamente através de dois tipos de metodologia, o biomonitoramento ativo e o passivo. O primeiro corresponde à exposição da planta indicadora ao ar contaminado, seja em câmaras de fumigação, onde há o controle da concentração e do tipo de poluente, ou às condições ambientais de determinada área sob impacto de poluentes para posterior análise laboratorial. Já o biomonitoramento passivo consiste na utilização de indivíduos preexistentes na área afetada, por exemplo próximo a indústrias, rodovias, áreas urbanas etc. (Flores, 1987; Arndt \& Schweizer 1991; Mazzoni-Viveiros, 1996).

A primeira via de contato entre a planta e o poluente gasoso são os órgãos assimiladores, principalmente a folha. Nela, a absorção do poluente se dá via cutícula ou estômato, assim como ocorre com a absorção de gás carbônico, sendo a taxa de absorção proporcional ao gradiente de concentração do poluente fora e dentro da folha, ao tempo 
de exposição da planta ao poluente, à capacidade de penetração do poluente (sua solubilidade), e à capacidade da planta de metabolizar a substância absorvida a formas menos tóxicas (Darrall, 1989; Weigel et al., 1989). Admite-se hoje que os efeitos da poluição na planta se iniciam em nível bioquímico, evoluem para um nível ultraestrutural, com desorganização das membranas, passando então para o nível celular de desestruturação do núcleo, chegando finalmente a sintomas visíveis como cloroses ou necroses do tecido foliar ou alteração no crescimento e desenvolvimento da planta (Malhotra \& Khan, 1984; Weigel et al., 1989; Iqbal et al., 1996).

Steubing \& Fangmeier (1991) identificaram a ação fitotóxica da poluição em vários níveis, desde efeitos nas populações, com a eliminação de espécies mais sensíveis, até efeitos fisiológicos, como mudanças nas taxas de fotossíntese, transpiração e condutância estomática, e efeitos bioquímicos, como modificações no metabolismo de açúcares, no conteúdo de pigmentos e na atividade de determinadas enzimas. Um dos principais efeitos tóxicos em nível celular, causados pelos poluentes atmosféricos gasosos, por exemplo $\mathrm{SO}_{2}, \mathrm{NO}_{2}$ e $\mathrm{O}_{3}$, é a formação de radicais livres como superóxidos e peróxidos, que bloqueiam o ciclo de Calvin levando então a alterações bioquímicas e fisiológicas. Embora muitas espécies possuam mecanismos antioxidantes de defesa, a absorção prolongada de poluentes pode exceder a capacidade de desintoxicação das células via metabolismo, causando injúrias nos tecidos e podendo levar ao declínio das comunidades vegetais (Malhotra \& Khan, 1984; Weigel et al., 1989; Iqbal et al., 1996).

As reações bioquímicas, assim como mudanças fisiológicas e químicas, podem ser utilizadas como parâmetros de avaliação em programas de biomonitoramento da poluição atmosférica. Entre os parâmetros do metabolismo vegetal afetados pelos poluentes aéreos que são mais freqüentemente utilizados em biomonitoramento podem ser citadas alterações na fotossíntese, no balanço hídrico, nas trocas gasosas, na atividade de enzimas (por exemplo peroxidase e catalase), nos teores de nutrientes e alguns metabólitos, e em alterações da superfície foliar, 
por exemplo na ornamentação da cutícula (Mudd \& Kozlowski, 1975; Jäger, 1982; Malhotra \& Khan, 1984; Darrall, 1989; Treshow \& Anderson, 1989; Weigel et al., 1989; Iqbal et al., 1996).

Outro efeito, já detectado mas pouco estudado, é a ação da poluição aérea na suscetibilidade da planta a patógenos e ao ataque de herbívoros. A poluição pode causar uma modificação da superfície foliar, facilitando a perda de água e cátions e também a penetração e infecção da folha por patógenos e/ou parasitas (Poborski, 1987), ou alterações nos teores de metabólitos secundários, provocando uma mudança na composição química da folha e, conseqüentemente na sua qualidade nutricional (Huttunen, 1984; Pell, 1987; Rowland et al., 1987a e 1987b).

Em princípio, achava-se que os compostos secundários não apresentavam uma função definida, que seriam apenas produtos finais do metabolismo primário utilizados como estoque de determinados elementos. Ainda não se estabeleceu um limite claro entre o metabolismo primário e o secundário, mas usualmente é definido que o metabolismo primário leva à síntese de açúcares, aminoácidos, ácidos graxos, nucleotídeos e polímeros derivados destes, como polissacarídeos, proteínas, lipídeos e ácidos nucléicos, todos essenciais à vida. Já o metabolismo secundário seria composto por rotas alternativas, que utilizam os produtos ou subprodutos do metabolismo primário, originando compostos não necessariamente essenciais ao organismo e que podem ser diferentes para cada espécie vegetal, sendo as três principais vias para a síntese de compostos secundários, a via do malonato, do ácido mevalônico e do ácido chiquímico (Fig. 1) (Seigler, 1977; Mann, 1987; Harborne, 1987).

Entretanto, o termo metabolismo secundário vem se mostrando pouco satisfatório, uma vez que muitos compostos secundários também estão envolvidos como reguladores de importantes processos bioquímicos, como por exemplo os ácidos giberélico, indolilacético, e abcísico, freqüentemente relacionados com o desenvolvimento e o crescimento das plantas, e as quinonas, envolvidas nos processos de respiração celular e fotossíntese, ou compostos voláteis, como 


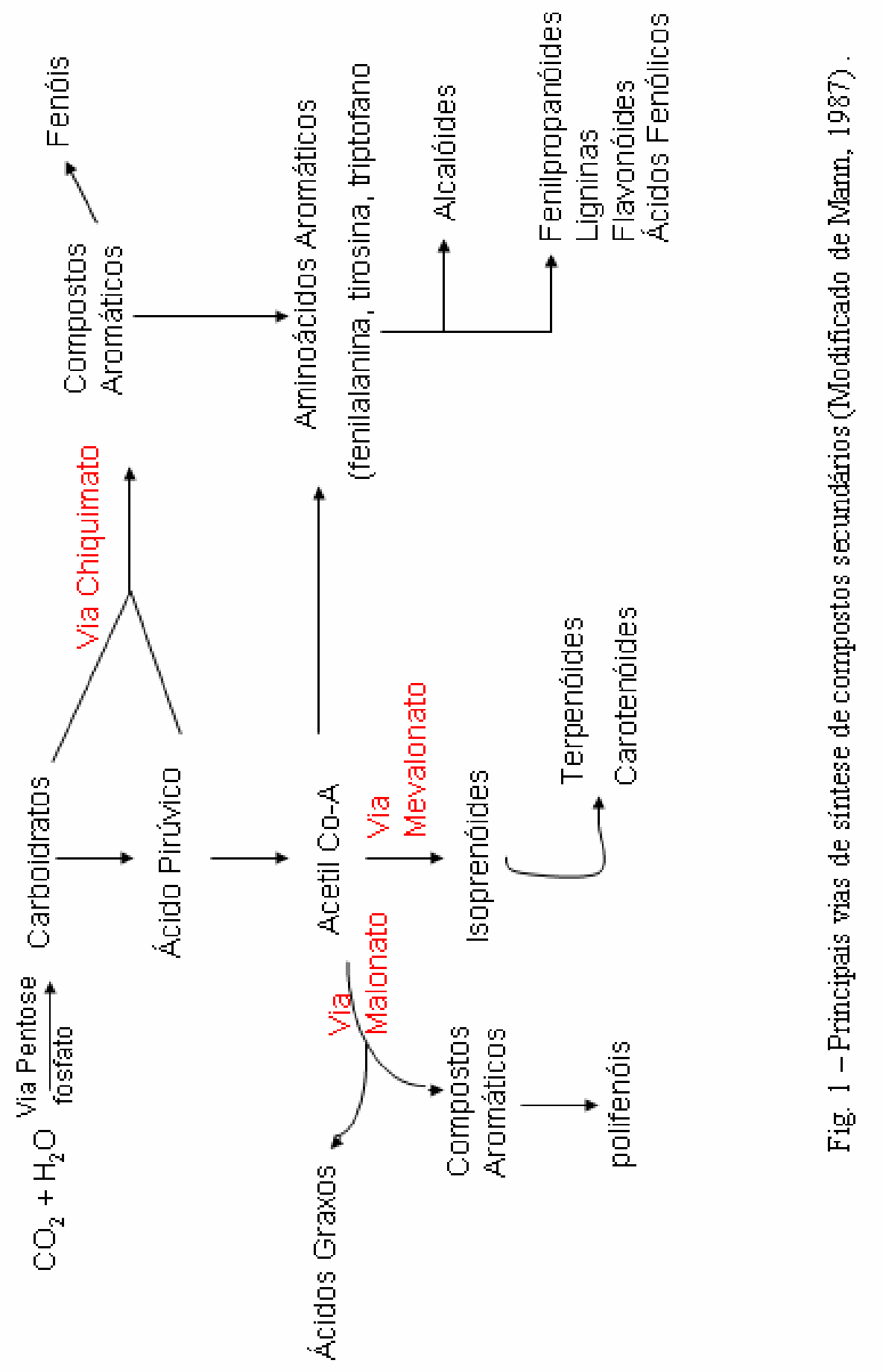


monoterpenos, envolvidos nas interações da planta com o meio (Whittaker \& Feeny, 1971; Bell, 1980; Bennett \& Wallsgrove, 1994).

Diversas classes de compostos secundários são consideradas defesas químicas da planta contra a ação de animais, fungos, bactérias e outras plantas, de forma que alterações na quantidade e/ou qualidade desses compostos poderiam afetar o sistema de defesa da planta, tornando-a assim mais suscetível à ação desses fatores bióticos (Seigler, 1977; Bell, 1980; Harborne, 1982, 1987; McNaughton, 1983; Huttunen, 1984; Coley et al., 1985; Flückiger et al., 1987; Louda \& Collinge, 1992; Appel, 1993; Bennett \& Wallsgrove, 1994).

Sabe-se hoje que a herbivoria exerce grande influência na comunidade de plantas, sendo uma das mais importantes relações entre plantas e insetos (McNaughton, 1983), pois aumenta a mortalidade dos indivíduos vegetais e remove biomassa que poderia ser alocada para o crescimento e reprodução (Coley et al., 1985), tornando-se assim um importante fator de seleção, especialmente em ambientes perturbados, onde a herbivoria pode intensificar o fator de estresse.

Vários trabalhos vêm demonstrando que a ação da poluição nos teores de metabólitos primários, como açúcares e aminoácidos, afeta por conseqüência a produção de determinados metabólitos secundários e estimulam o ataque de herbívoros. Alterações nesses teores implicam em mudanças na capacidade de atração ou defesa da planta, como verificado nos trabalhos citados por Flückiger e colaboradores (1987). Esses autores mencionam, por exemplo, que o aumento de etanol produzido por Pinus resinosa, quando em presença de $\mathrm{SO}_{2}$ ou $\mathrm{O}_{3}$, de um lado, levou a uma forte ação repelente para o besouro Monochamus alternatus, e de outro lado, a uma atração de Agrilus bilineatus, Gnathothrinchus sulcatus e Trypodendron lineatum. Cobb e colaboradores (1972) também relatam o efeito de poluentes fotoquímicos nos teores de monoterpenos, provocando maior infestação do besouro 
Dendroctonus brevicomis e D. ponderosae em Pinus ponderosa. Kainulainen e colaboradores (1994) verificaram que o ozônio reduz os níveis de amido e aminoácidos livres em Pinus sysvestris, podendo resultar, se em maiores concentrações do poluente ou maiores períodos de exposição, em alterações nos compostos secundários e na infestação pelo afídeo Schizolachnus pineti. Hautala \& Holopainen (1995) observaram que determinadas concentrações de fluoretos causam um aumento na quantidade de aminoácidos livres e estimulam a síntese de alcalóides em Hordeum vulgare, influenciando na infestação pelo afídeo Rhopalosiphum pardi.

Durante as últimas décadas, os estudos de biomonitoramento da qualidade do ar em áreas industrializadas tornaram-se um eficiente instrumento no controle e mapeamento da poluição aérea, principalmente nos países desenvolvidos (Prasad \& Rao, 1985; Klumpp et al., 1994a; 1996). Para os países em desenvolvimento, os problemas ambientais resultantes do intenso crescimento da industrialização e urbanização, ao lado da falta de um controle efetivo, da falta de investimentos na área ambiental, e da dificuldade na utilização de tecnologias modernas e dispendiosas, o biomonitoramento torna-se um instrumento potencialmente eficiente como método alternativo de controle de poluição atmosférica.

\section{POLUIÇÃO EM CUBATÃO}

No Brasil, na década de 70, foram criadas algumas agências nacionais e estaduais responsáveis pelo monitoramento e controle da poluição ambiental. Entretanto, somente a partir de 1976 foram estabelecidos padrões de qualidade do ar para determinados poluentes atmosféricos e começaram a aparecer na literatura dados referentes aos estudos da composição química da atmosfera em algumas grandes cidades brasileiras e seus índices de poluição. 
Em meados da década de 80, diante da pressão causada por denúncias de problemas ambientais ocorridos em todo o Brasil, foram sendo criados programas para o controle da poluição ambiental, entre eles o programa de controle de poluição em Cubatão em 1983 (Vasconcelos \& Abreu, 1987; Galvão Filho, 1988). A partir daí, os padrões aceitáveis de poluição atmosférica foram revistos e, em 1990, foram ampliados pelo IBAMA com a inclusão de novos parâmetros. Foram compostos, então, os Padrões Nacionais de Qualidade do Ar (PNQA) (portaria n. ${ }^{\circ} 348$ de 14/03/90), que regulamentam dois tipos de padrões de qualidade do ar: os padrões primários, ou seja níveis máximos toleráveis de concentração de poluentes atmosféricos, e os padrões secundários, ou níveis desejados de concentração de poluentes. Os valores estabelecidos pela Resolução CONAMA n. ${ }^{\circ} 3$ de 28/06/90 que constituem os Padrões Nacionais de Qualidade do Ar (PNQA) para sete tipos de poluentes são: partículas totais em suspensão (240 $\mu \mathrm{g} / \mathrm{m}^{3}$ como padrão primário e $150 \mu \mathrm{g} / \mathrm{m}^{3}$ como padrão secundário), dióxido de enxofre $\left(\mathrm{SO}_{2}, 365 \mu \mathrm{g} / \mathrm{m}^{3}\right.$ padrão primário, e $100 \mu \mathrm{g} / \mathrm{m}^{3}$ padrão secundário), monóxido de carbono ( $\mathrm{CO}, 10.000$ $\mu \mathrm{g} / \mathrm{m}^{3}$ padrão primário e secundário), ozônio $\left(\mathrm{O}_{3}, 160 \mu \mathrm{g} / \mathrm{m}^{3}\right.$ padrão primário e secundário), fumaça $\left(150 \mu \mathrm{g} / \mathrm{m}^{3}\right.$ como padrão primário e $100 \mu \mathrm{g} / \mathrm{m}^{3}$ como secundário), partículas inaláveis $\left(150 \mu \mathrm{g} / \mathrm{m}^{3}\right.$ padrão primário e secundário) e dióxido de nitrogênio $\left(\mathrm{NO}_{2}, 320\right.$ $\mu \mathrm{g} / \mathrm{m}^{3}$ como padrão primário e $190 \mu \mathrm{g} / \mathrm{m}^{3}$ como padrão secundário) (Alonso \& Godinho, 1992; Miguel, 1992; CETESB, 1997).

Entretanto, sabe-se que concentrações de 70 $\mu \mathrm{g} / \mathrm{m}^{3}$ de dióxido de enxofre, $30 \mu \mathrm{g} / \mathrm{m}^{3}$ de dióxido de nitrogênio e $150 \mu \mathrm{g} / \mathrm{m}^{3}$ de ozônio são críticas para plantas de florestas temperadas ou outras formas de vegetação (Ashmore \& Wilson, 1992, apud Pompéia, 1997), indicando que, em geral, a vegetação requer níveis de poluição inferiores aos tolerados pelos humanos e, desta forma, é interessante a utilização de ambos os parâmetros para elaboração de padrões de qualidade do ar mais fiéis à realidade. 
Uma iniciativa relacionada ao uso de bioindicadores e programas de biomonitoramento da poluição atmosférica no Brasil, é o acordo de colaboração do governo brasileiro, através da SMA (Secretaria de Estado do Meio Ambiente), com o governo alemão, através do GKSS (Forschungszentrum Geesthacht $\mathrm{GmbH}$ ), envolvendo vários institutos de pesquisa brasileiros e alemães, para o desenvolvimento de estudos na região da Serra do Mar e Cubatão. Tais estudos foram iniciados em 1989, após o histórico de grandes deslizamentos de terra ocorridos nas encostas da serra mais atingidas pela poluição emitida pelas indústrias especialmente em 1985, e que atingiram não somente a população local como também as instalações industriais de Cubatão. As pesquisas tiveram o intuito de conhecer melhor a dispersão, transformação e deposição de poluentes na região de Cubatão e verificar se os níveis locais de poluição, considerados como dentro dos padrões nacionais (exceto para o caso de $\mathrm{O}_{3}$ e partículas inaláveis, que excedem os limites) ainda causam ações tóxicas na vegetação exposta à poluição atmosférica emitida pelo pólo industrial de Cubatão e às alterações induzidas no solo (Targa \& Klochow, 1997).

Como parte desse grande projeto, o Instituto de Botânica, juntamente com as Universidades alemãs de Essen e Kassel, começaram a desenvolver estudos de biomonitoramento da poluição atmosférica através da avaliação de danos visíveis e de alterações químicas, físiológicas e bioquímicas em algumas espécies exóticas, já padronizadas como bioindicadoras, e em espécies nativas, assim como estudos de caracterização química e estrutural dos solos da região.

Em particular, alguns estudos com Tibouchina pulchra Cogn. (Manacá-da-Serra), espécie predominante na região de Cubatão, vêm sendo desenvolvidos a fim de verificar a influência da poluição na química, fisiologia e bioquímica dessa espécie e suas conseqüências no crescimento e desenvolvimento da planta, assim como alterações estruturais de folhas e lenho. Podem 
ser citados os trabalhos de Diniz et al., 1994; Fialho et al. 1994; Klumpp et al., 1994b; Furlan et al., 1995; Mazzoni-Viveiros, 1996; Modesto et al., 1996; Klumpp et al., 1997; Pradella, 1997; Domingos, 1998; Fialho, 1998, entre outros.

\section{OBJETIVOS}

O presente trabalho foi proposto considerando a hipótese de que os níveis atuais de poluentes atmosféricos na região de Cubatão, em São Paulo, variáveis ao longo do ano, podem causar alterações nas concentrações foliares de nitrogênio, compostos fenólicos, taninos, fibras e ligninas em Tibouchina pulchra, espécie secundária nativa da Mata Atlântica local, e que essas alterações podem levar a mudanças na qualidade nutricional das folhas e, em conseqüência, nas relações planta-herbívoros e na intensidade de herbivoria foliar.

$\mathrm{O}$ objetivo deste estudo foi analisar se indivíduos de Tibouchina pulchra que ocorrem nos trechos de floresta da Serra do Mar atingidos por diferentes tipos e cargas de poluentes aéreos emitidos em Cubatão, sofrem alterações, também influenciadas pela época do ano, nos conteúdos dos compostos acima mencionados e se essas alterações levam ou não a uma maior suscetibilidade da folha ao ataque de herbívoros. 


\section{MATERIAL E MÉTODOS}

\section{CARACTERIZAÇÃO DA ÁREA DE ESTUDO}

A Serra do Mar estende-se desde o Nordeste brasileiro até o Sul de Santa Catarina. Surgiu no período Cretáceo, devido a falhas, fendas e rupturas ocorridas durante o levantamento andino, atingindo hoje alturas de até $900 \mathrm{~m}$ acima do nível do mar, apresentando principalmente formações rochosas de quartzo, gnaisse, granitos e xisto (Bragança et al., 1987; Gutberlet, 1996). Em São Paulo, considera-se Serra do Mar as escarpas e espigões que separam o Planalto Atlântico da Planície Litorânea, configurando uma paisagem de declividades acentuadas (SMA, 1990).

Os solos, principalmente dos tipos podzol e latossolo amarelo/vermelho, possuem profundidades que variam ao longo da serra, tendo-se solos profundos nas áreas mais planas, solos com até $2 \mathrm{~m}$ de profundidade nas encostas, e solos novamente profundos no sopé da serra, devido à deposição de sedimentos (Gutberlet, 1996). A estrutura, granulometria e fertilidade dos solos da Serra do Mar também variam bastante em função do acentuado gradiente topográfico e da dinâmica das escarpas (Pompéia, 1997). Em geral, são solos ácidos com baixos teores de $\mathrm{Ca}, \mathrm{Mg}, \mathrm{K}$ e $\mathrm{Na}$, devido ao alto índice pluviométrico que resulta em maior lixiviação de bases trocáveis nos solos (Leitão Filho, 1993; Mayer \& Lopes, 1997; Pompéia, 1997).

No limite entre os climas tropical e subtropical, o clima regional da Serra do Mar é geralmente dominado por massas de ar tropicais e subantárticas. Devido à influência dessas massas de ar e do efeito orográfico de retenção, a região possui média anual de umidade relativa do ar de 70 a $90 \%$ e índice pluviométrico dependente da orografia, sendo em média de $3000 \mathrm{~mm}$ na borda das escarpas da serra (700 m) e de 2600 mm na base das encostas (Bragança et al., 1987; Gutberlet, 1996; Mayer \& Lopes, 1997), definindo um clima tropical super-úmido, sem período de estiagem ao longo do ano (Setzer, 1976, apud Pompéia, 1997). 
Com os altos índices pluviométricos e altas temperaturas (20$25^{\circ} \mathrm{C}$ ), são intensos os processos de decomposição, e as rochas metamórficas sofrem rápida intemperização, que unida à inclinação da encosta (declividades entre 40 e $90^{\circ}$ ) e ao fluxo de água, levam a uma diminuição da resistência dos fatores físicos do solo gerando movimentos de massa e deslizamentos (Troppmair \& Ferreira, 1987; Bragança et al., 1987; Gutberlet, 1996; Mayer \& Lopes, 1997).

A vegetação da Serra do Mar, denominada Mata Atlântica, originalmente estendia-se ao longo da costa atlântica brasileira. Atualmente, restam apenas entre 1 a $5 \%$ dessa formação, distribuídos em fragmentos, estando situados no Sudeste do Brasil os melhores e mais preservados remanescentes, particularmente nos Estados de São Paulo e Paraná (Câmara, 1991; Leitão Filho, 1993). Destes, 2 a 3\% estão localizados nas proximidades dos centros mais desenvolvidos do país, como o trecho da região da Baixada Santista, Município de Cubatão, São Paulo.

Vantagens como a proximidade do porto de Santos (facilidade para exportação/importação), possibilidade de obtenção de energia hidrelétrica, e ampla rede de drenagem para abastecimento e lançamento de detritos, foram decisivas para os primeiros investimentos na região logo no começo do século XIX, iniciando-se assim a fase de industrialização da região, a qual resultou na formação do atual complexo industrial de Cubatão (Troppmair \& Ferreira, 1987; Gutberlet, 1996).

Segundo Gutberlet (1996), existiram três grandes períodos de desenvolvimento em Cubatão. A primeira fase, a colonial, foi caracterizada pelo comércio e transporte de produtos estrangeiros e agrícolas entre o porto e o planalto; na segunda fase, de industrialização inicial, foram implantadas as primeiras indústrias da região; a terceira fase coincide com a posse do presidente Vargas, a partir de 1930, onde foram intensificadas as atividades industriais com o estabelecimento de novas indústrias na região.

A primeira indústria a surgir em Cubatão foi a Cia. Curtidora Mex, em 1895, seguida pela instalação das Cia. Anilinas e Produtos Químicos 
do Brasil e da Cia. Santista de Papel, que proporcionaram novos empregos e um grande estímulo para a expansão de Cubatão, principalmente após a inauguração, em 1925, da Rodovia do Caminho do Mar, que ligava a capital paulista à Baixada Santista. Com condições propícias, como investimento para construção de indústrias, energia elétrica fornecida pela usina instalada na região pela Light and Power, abastecimento e eliminação de água servida e de esgoto pela ampla rede fluvial, transporte através da ampliação e construção de novas rodovias (Anchieta em 1949; Piaçaguera em 1959, e Imigrantes em 1972), mãode-obra barata (migrantes), e grande apoio governamental, a região de Cubatão teve um rápido desenvolvimento principalmente entre as décadas de 50 e 60 . Somente com a crise econômica mundial em 1973/1974 houve uma redução no crescimento da região, agravando-se também os problemas sociais e econômicos já existentes devido ao desenvolvimento desordenado e mal planejado. Mesmo assim, o complexo industrial de Cubatão ainda é considerado como o centro de produção mais importante de matéria-prima e produtos semi-acabados nas áreas petroquímica e metalúrgica (Bragança et al., 1987; Troppmair \& Ferreira, 1987; Gutberlet, 1996; Targa \& Klockow, 1997).

Com extensão de cerca de $11 \mathrm{~km}$ e 2 a $4 \mathrm{~km}$ de largura (Fig. 2), possui 11 indústrias químicas/petroquímicas, 7 fábricas de fertilizantes, 1 de mineral não metálico, 1 de papel/papelão e 1 de cimento, citando-se apenas as atividades de grande porte, e aproximadamente 110 unidades de produção e mais de 300 fontes principais de poluição do ar, água e do solo (Galvão Filho, 1988; Alonso \& Godinho, 1992; SMA, 1993). Parte da poluição existente na região é devida ao tráfego de cerca de 6 milhões de automóveis e 1,5 milhões de caminhões nas rodovias locais, mas o maior poluidor é a indústria de base, que lança aproximadamente 30 mil toneladas de poluentes por dia, sendo $50,8 \%$ de gases inorgânicos, $37 \%$ de pó em suspensão, $11,8 \%$ de gases e vapores orgânicos e $0,4 \%$ de ácidos (Gutberlet, 1996; Jaeschke, 1997).

A ação da poluição é um fator existente há pelo menos duas décadas, quando o quadro atual das indústrias já havia se completado (Leitão Filho, 1993). A partir da inauguração da refinaria de Petróleo 


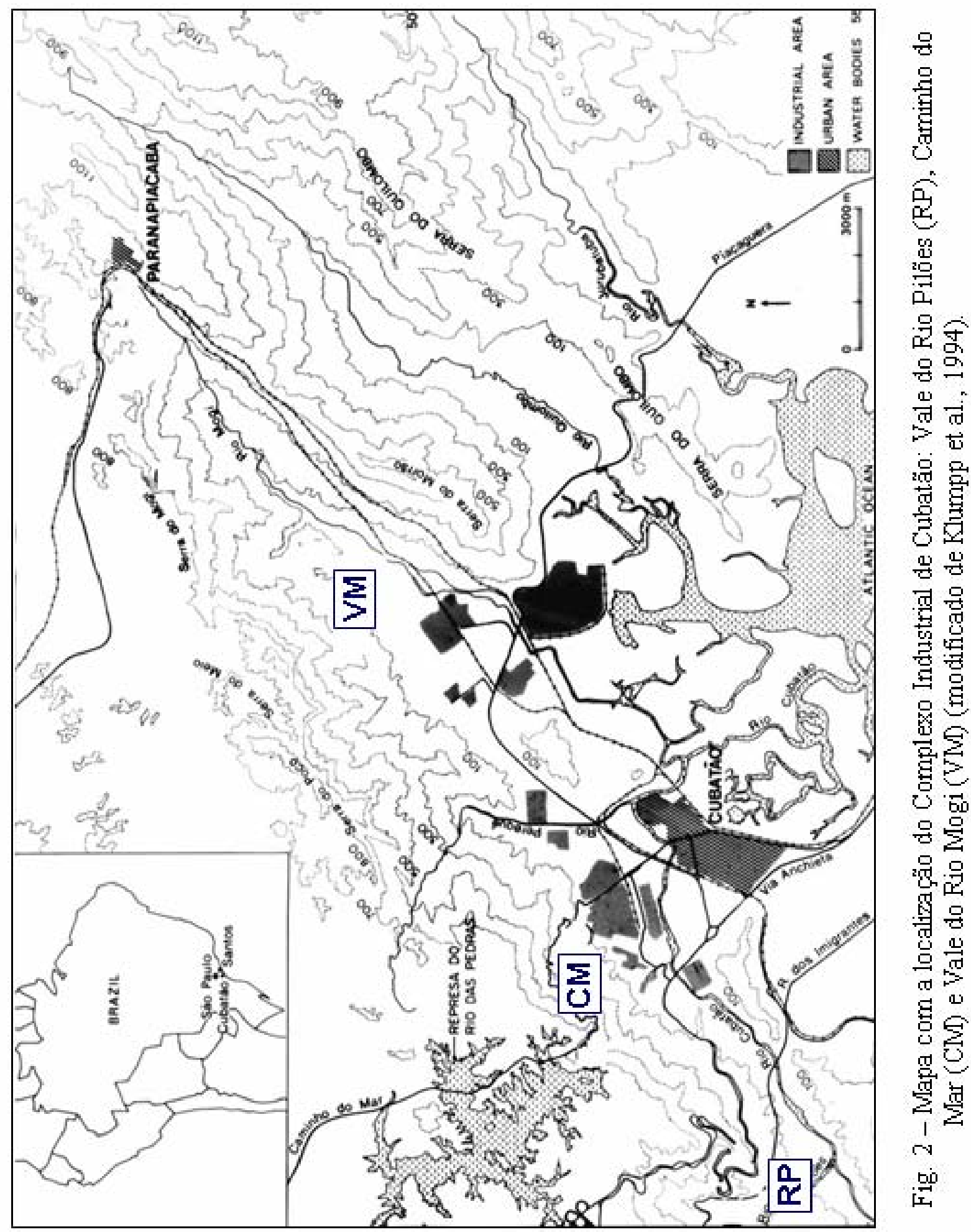


Presidente Bernardes, em 1954, e da Cia. Siderúrgica Paulista (COSIPA), em 1962, o grande desenvolvimento industrial de forma mal planejada e/ou controlada, provocou elevados índices de poluição emitida principalmente por indústrias dos ramos petroquímico, químico, siderúrgico e metalúrgico.

Segundo dados da CETESB (1992), em Cubatão foram emitidos pelos processos industriais 114.416 ton./ano de poeiras (emitidos principalmente por indústrias de fertilizantes e siderurgia), 32.807 ton./ano de hidrocarbonetos (principalmente pela indústria petroquímica), 28.358 ton./ano de $\mathrm{SO}_{2}$ (emitido por indústrias de fertilizantes, siderurgia e de petróleo), 22.297 ton./ano de $\mathrm{NO}_{\mathrm{x}}$ (emitido por indústrias de fertilizantes, siderurgia e de petróleo), 3.189 ton./ano de $\mathrm{NH}_{3}$ (via indústrias de fertilizantes) e 956 ton./ano de fluoretos (pelas indústrias de fertilizantes) (Targa \& Klockow, 1997). Em 1994, as estimativas de emissão de poluentes por processos industriais e queima de combustível em fontes estacionárias em Cubatão, segundo dados da CETESB (1995 e 1997), são de $32 \mathrm{mil}$ ton./ano de material particulado, 17 mil ton./ano de dióxido de enxofre, $17 \mathrm{mil}$ ton./ano de óxidos de nitrogênio, 70 ton./ano de fluoretos, 70 ton./ano de amônia e 4 mil ton./ano de compostos orgânicos voláteis, indicando que está havendo uma redução nos níveis de poluição local que é atribuído, segundo dados das publicações, a investimentos no controle da poluição ambiental por parte das indústrias.

Sua localização praticamente nas encostas da Serra do Mar, e a direção dos ventos predominantemente do mar para o continente, fazem com que a serra funcione como uma barreira, dificultando a dispersão dos poluentes e elevando sua concentração na região (Leitão Filho, 1993). Impacto adicional pode ser provocado através dos ventos equatoriais tropicais e tropicais continentais que trazem poluição de outras regiões altamente industrializadas e urbanizadas de São Paulo, como São Bernardo do Campo, por exemplo (Gutberlet, 1996; Fiedler \& Massambani, 1997).

$\mathrm{Na}$ figura 3 está representada, de forma simplificada, a circulação atmosférica na região de Cubatão. Durante o dia, com a predominância 

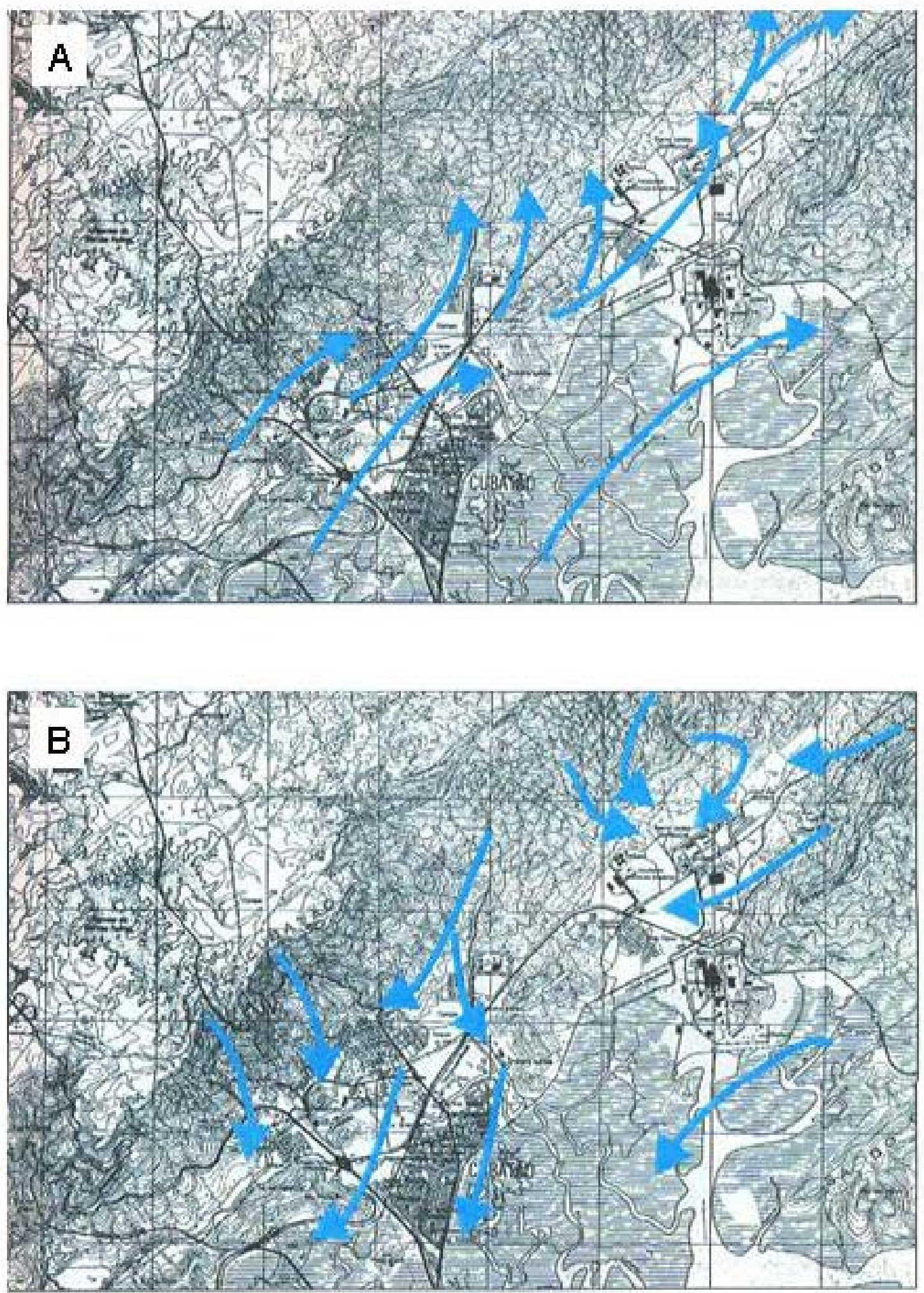

Fig. 3 - Representação da circulação atmosférica na região da Serra do mar e Cubatão: A. período diurno; B. período noturno (retirado de Pompéia, 1997). 
dos ventos no sentido mar-continente, os poluentes emitidos no pólo industrial são carregados encosta acima, afetando principalmente os Vales do Rio Mogi e do Rio Perequê e as encostas próximas ao Caminho do Mar (Fig. 3A). No período noturno, há a inversão do sentido dos ventos e os poluentes são carregados no sentido do oceano, havendo maior dispersão, uma vez que não há a serra como barreira (Fig. 3B) (Pompéia, 1997). Como resultado, observam-se extensas áreas degradadas e a morte de um grande número de plantas. Da vegetação original, os remanescentes são escassos e a maior parte da floresta que persiste é secundária, em diferentes estágios sucessionais (Leitão Filho, 1993), ocorrendo apenas nas regiões isoladas e protegidas dos ventos, ou afastadas do pólo industrial.

A vegetação original era constituída por extensos manguezais e florestas de variadas fisionomias, desde florestas de planície costeira até as de encosta, principalmente no lado leste da Serra. Foi descaracterizada, já no período de colonização, por extrativismo, intensificado em 1918 com a inauguração da Cia. Santista de Papel, atividades agrícolas, como plantio de cana-de-açúcar e banana, e, mais recentemente, pelo desenvolvimento urbano. Segundo dados da CETESB (1991), dos $148 \mathrm{~km}^{2}$ do município de Cubatão, $91 \mathrm{~km}^{2}$ eram originalmente recobertos por Mata Atlântica, $24 \mathrm{~km}^{2}$ por matas de restinga e $29 \mathrm{~km}^{2}$ por manguezais. Resta atualmente $75 \mathrm{~km}^{2}$ degradados pela poluição industrial e apenas $10 \mathrm{~km}^{2}$ em bom estado de preservação.

A distribuição espacial das fontes emissoras de poluição no complexo industrial de Cubatão, e a topografia local não favorável à dispersão dos poluentes atmosféricos, delimitam áreas caracterizadas pela presença de diferentes poluentes, tanto quantitativa como qualitativamente (SMA, 1993; CETESB, 1984). Esse fator levou à seleção e escolha das áreas amostrais utilizadas durante o convênio Brasil/Alemanha nos estudos desenvolvidos na região, que foram as mesmas utilizadas neste projeto e que são descritas a seguir (Fig. 2):

- Vale do Rio Pilões (RP), a sudoeste do complexo industrial. É considerada área de referência por estar relativamente protegida dos 
ventos vindos do complexo industrial (Fig. 4). Localizada próximo à captação de água da SABESP, recebe alguma influência do efeito antrópico de ocupação do vale e da poluição emitida por automóveis devido à proximidade das rodovias Anchieta e dos Imigrantes. Segundo Domingos (1998), em levantamentos realizados nessa área durante o período de 1991 a 1995, foram observados valores médios anuais de $3376 \mathrm{~mm}$ de precipitação, $22,6^{\circ} \mathrm{C}$ de temperatura e $87,2 \%$ de umidade relativa do ar.

Não está completamente isenta da presença da poluição aérea emitida em Cubatão, devido à influência do regime de ventos da região, que é predominantemente NW trazendo consigo uma parte dos poluentes emitidos no complexo industrial (Jaeschke, 1997). Segundo dados da estação de monitoramento instalada nas imediações dessa área e cedidos pelo módulo de Química do projeto Brasil/Alemanha, foram encontrados, como valores médios para o período de 1991 a 1994, $7,6 \mu \mathrm{g} / \mathrm{m}^{3}$ de gases $\mathrm{NO}_{\mathrm{x}}, 5,43 \mu \mathrm{g} / \mathrm{m}^{3}$ de $\mathrm{SO}_{2}$ e $29 \mu \mathrm{g} / \mathrm{m}^{3}$ de $\mathrm{O}_{3}$.

Segundo Leitão Filho (1993), a vegetação é mais densa e as árvores atingem maior porte, podendo ser considerada uma floresta atlântica de encosta de formação secundária, mas ainda em bom estado de conservação e em processo de estratificação e substituição de espécies. Em levantamento realizado por Pompéia (1997), foram encontradas 38 famílias, 69 gêneros e 77 espécies nessa área, com a predominância, em número de indivíduos, de Nyctaginaceae e Euphorbiaceae.

- Caminho do Mar (CM), área que se estende ao longo da antiga estrada de ligação entre Santos e São Paulo (Fig. 5). Segundo Domingos (1998), em levantamentos realizados durante o período de 1991 a 1995, foram observados, para esta área, valores médios anuais de $3066 \mathrm{~mm}$ de precipitação, $21,9^{\circ} \mathrm{C}$ de temperatura e $84 \%$ de umidade relativa do ar.

A região é atingida por poluentes orgânicos (como hidrocarbonetos), secundários (como ozônio e nitrato de peroxiacetila PAN) e compostos gasosos de nitrogênio e enxofre, devido à próxima localização da refinaria de petróleo Presidente Bernardes na base da 


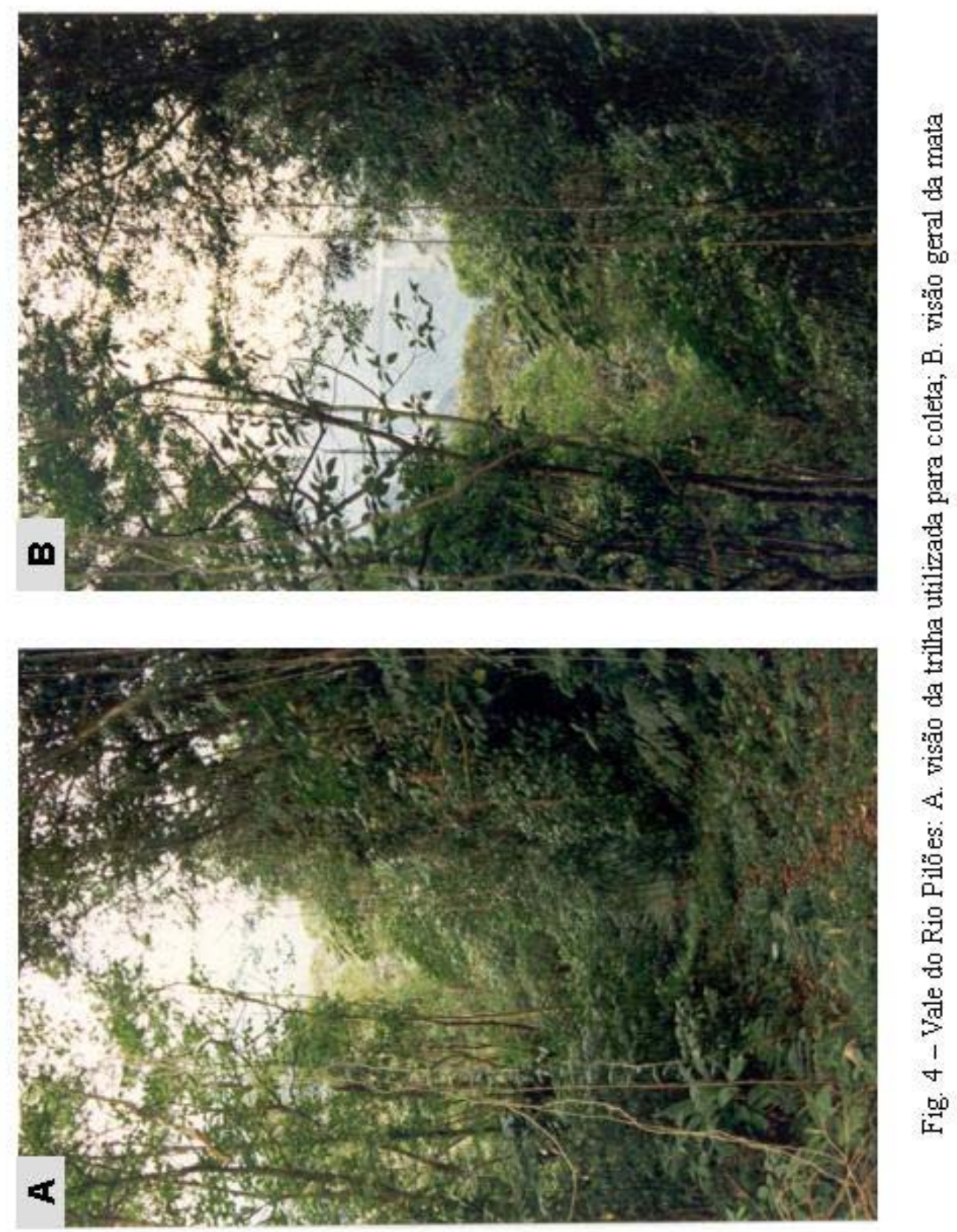




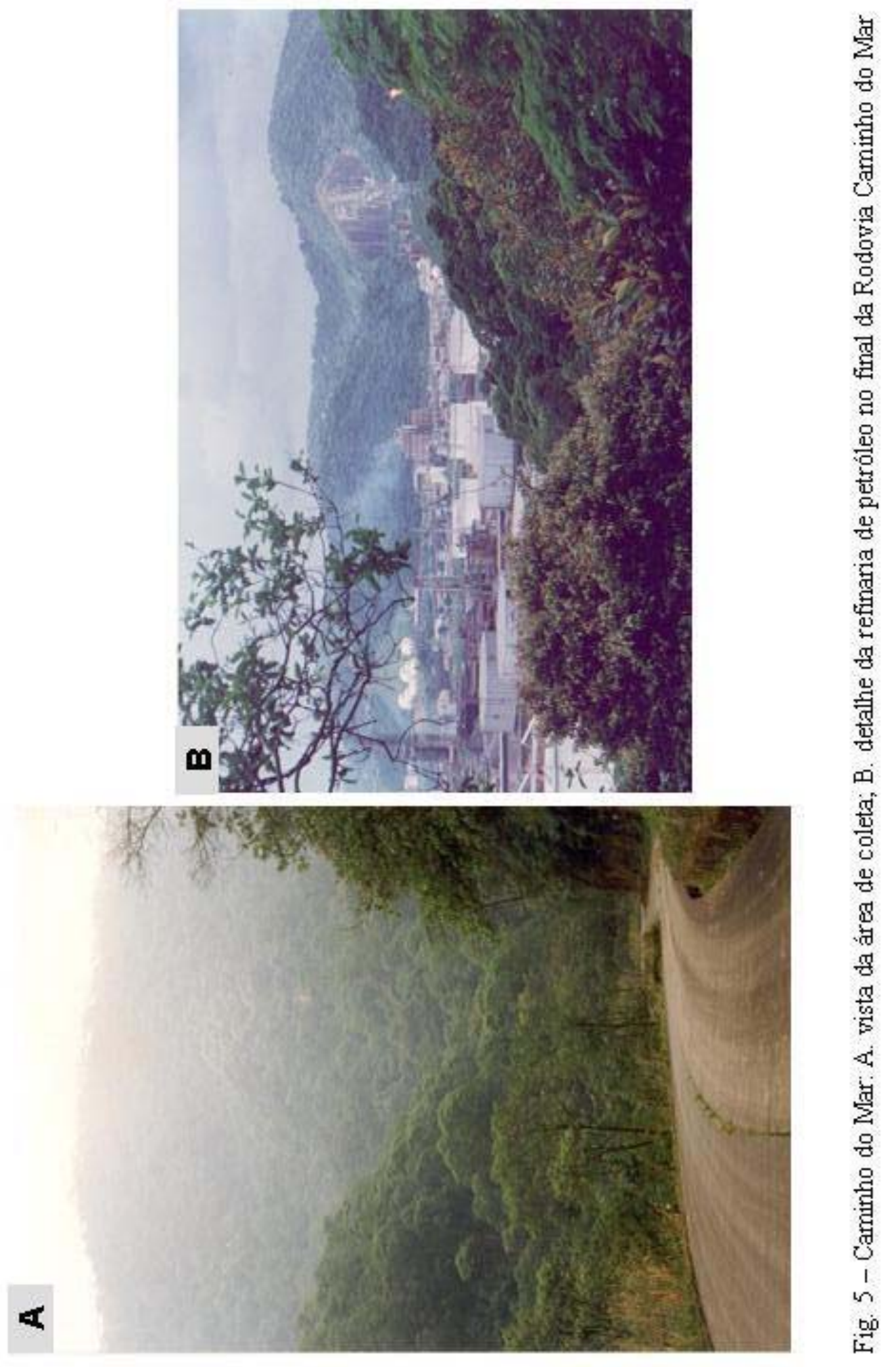


estrada Caminho do Mar (Klumpp et al., 1994a). Segundo Pompéia (1997), em 1994, 97\% da poluição emitida na área do Caminho do Mar era composta por gases e 3\% por poeiras. Dos gases, $53 \%$ era de $\mathrm{SO}_{2}$ (7033 ton./ano), 29\% de $\mathrm{NO}_{\mathrm{x}}$ (3767 ton./ano), 18\% de hidrocarbonetos (2391 ton./ano), enquanto que foram lançadas 7570 ton./ano de poeiras nessa área. Segundo dados da estação de monitoramento instalada nas imediações desta área e cedidos pelo módulo de Química do projeto Brasil/Alemanha, foram encontrados, como valores médios para o período de 1994 e 1995, 19,75 $\mu \mathrm{g} / \mathrm{m}^{3}$ de gases $\mathrm{NO}_{\mathrm{x}}, 45,5 \mu \mathrm{g} / \mathrm{m}^{3}$ de $\mathrm{SO}_{2}$ e $80,2 \mu \mathrm{g} / \mathrm{m}^{3}$ de $\mathrm{O}_{3}$.

A vegetação local é secundária e episódios de deslizamentos ainda são freqüentes nessa região. Em levantamento fitossociológico, foram encontradas 39 famílias, 67 gêneros e 74 espécies, com a predominância, em número de indivíduos, de Melastomataceae e Rubiaceae (Pompéia, 1997).

- Vale do Rio Mogi (VM), área situada na entrada do Vale do Rio Mogi, compreendendo a região industrial de Vila Parisi, sendo a área de coleta pertencente a indústria de fertilizantes Ultrafértil S.A. (Fig. 6). Domingos (1998), em levantamentos realizados durante o período de 1991 a 1995, observou, para esta área, valores médios anuais de 2559 $\mathrm{mm}$ de precipitação, $21,9^{\circ} \mathrm{C}$ de temperatura e $84 \%$ de umidade relativa do ar.

Essa região é considerada como fortemente afetada pela poluição industrial, com $63 \%$ da poluição emitida na região composta por gases e $37 \%$ por poeiras (Pompéia, 1997). Encontram-se na região materiais particulados (média anual de 50-150 $\mathrm{\mu g} / \mathrm{m}^{2}$ ), compostos gasosos de nitrogênio (20-40 ppb $\mathrm{NO}_{\mathrm{x}}, \quad 10-60$ ppb $\mathrm{NH}_{3}, \quad 1,5$ ppb $\mathrm{NO}_{3}$, correspondendo a $57 \%$ dos gases emitidos) e de enxofre (3-12 ppb $\mathrm{SO}_{2}$, correspondendo a $37 \%$ dos gases emitidos), além de fluoretos (até 2,5 ppb), devido à proximidade de indústrias siderúrgicas, químicas, de fertilizantes e de cerâmica agrupadas na entrada do vale (Jaeschke, 1997; Pompéia, 1997). Segundo dados de levantamentos feitos por Pompéia (1997), das 31.645 ton./ano de poeiras emitidas na região de Cubatão, 31.056 foram lançadas por indústrias localizadas na área do Vale do 


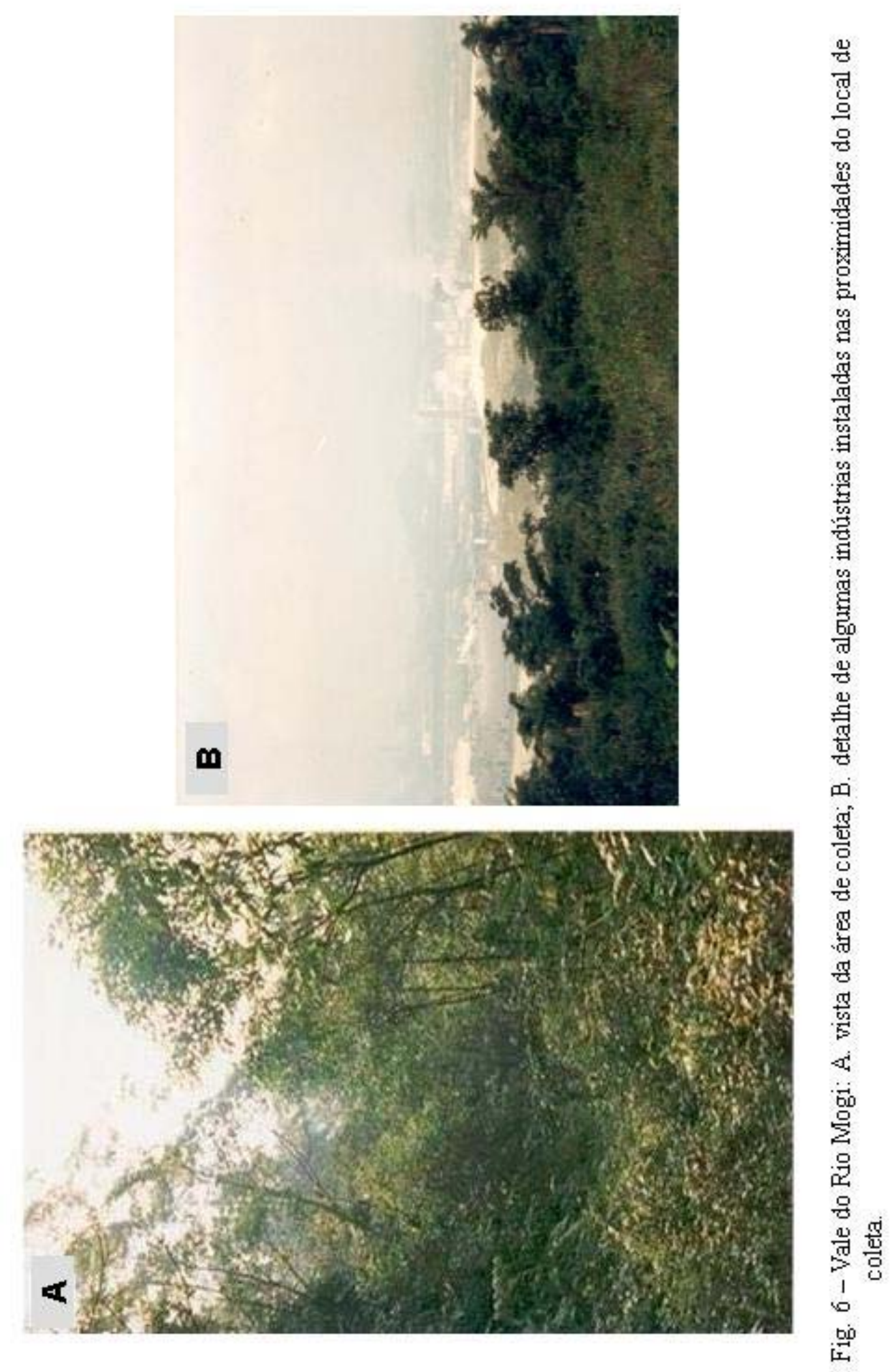


Mogi. Das 17.286 ton./ano de gases $\mathrm{NO}_{\mathrm{x}}$ e 17.000 ton./ano de gases $\mathrm{SO}_{\mathrm{x}}$ emitidas na região de Cubatão, 12.751 e 8.200 ton./ano, respectivamente, correspondem a emissões desses gases na região do Vale do Rio Mogi. Segundo dados da estação de monitoramento instalada nas imediações dessa área e cedidos pelo módulo de Química do projeto Brasil/Alemanha, foram encontrados, como valores médios para o período de 1991 e $1995,26,22 \mu \mathrm{g} / \mathrm{m}^{3}$ de gases $\mathrm{NO}_{\mathrm{x}}, 30,25 \mu \mathrm{g} / \mathrm{m}^{3}$ de $\mathrm{SO}_{2}$ e $29,4 \mu \mathrm{g} / \mathrm{m}^{3}$ de $\mathrm{O}_{3}$.

O Vale do Rio Mogi apresenta uma vegetação secundária, com árvores remanescentes esparsamente distribuídas, não chegando a formar um dossel contínuo e, portanto, com estrato herbáceo mais desenvolvido (Leitão Filho, 1993), criando um processo permanente de regeneração, através da qual as espécies heliófilas, pioneiras e tolerantes à poluição são favorecidas. Pompéia (1997) encontrou 30 famílias, 53 gêneros e 44 espécies, com a predominância, em número de indivíduos, de Melastomataceae e Meliaceae.

\section{MATERIAL}

Nas áreas poluídas, há a morte seletiva de espécies, o que torna o dossel heterogêneo e permite, ao longo do perfil vertical da floresta, a convivência de espécies pioneiras com espécies de estágios mais tardios da sucessão. Para Pompéia (1997), as Melastomataceae passaram a ter destaque na composição florística da região após o início das emissões industriais, devido ao domínio de espécies pioneiras pertencentes ao grupo. Mesmo na área do Vale do Mogi, bastante afetada pela poluição, o número de espécies dessa família é praticamente igual ao número encontrado nas áreas do Rio Pilões e Caminho do Mar (sete espécies no VM, sete espécies no CM, oito espécies no RP).

Segundo a SMA (1990), Leitão Filho (1993), CETESB (1995), Pompéia (1997), Pradella (1997) e outros estudos fitossociológicos desenvolvidos na região, nas três áreas acima descritas ocorre grande número de indivíduos de Tibouchina pulchra Cogn. (Melastomataceae) amplamente distribuídos, em vários estágios sucessionais. Trata-se de 
espécie arbórea pioneira, nativa das formações secundárias de Mata Atlântica que ocorre na região de Cubatão. Parece ser tolerante à poluição local, conseguindo se estabelecer e completar todas as fases do seu ciclo de vida.

Tibouchina pulchra, além de outras espécies arbóreas e herbáceas, foi escolhida por Pompéia e colaboradores (1989), para realização de semeadura aérea para recuperação da cobertura vegetal da Serra do Mar na região de Cubatão, devido aos critérios: ocorrência natural na região; distribuição nos estratos herbáceo, arbustivo e arbóreo; alto potencial de dispersão; alto poder de germinação; rápido desenvolvimento; alta agressividade na ocupação da área; resistência à poluição atmosférica; e disponibilidade de sementes para a coleta.

A ampla distribuição de Tibouchina pulchra, aliada a inúmeros trabalhos já desenvolvidos para investigação de efeitos bioquímicos e fisiológicos da poluição nessa espécie, foram motivos que levaram à sua utilização no presente estudo.

Foram coletadas folhas maduras, já expandidas mas ainda não senescentes, de indivíduos de Tibouchina pulchra, situados nas bordas das porções de floresta de cada área amostrada. As árvores tinham, em média, 2,5 $\mathrm{m}$ de altura. As amostragens das folhas de cada indivíduo (5 indivíduos em cada uma das três áreas amostrais para cada coleta) foram realizadas nos meses de janeiro, fevereiro, junho e julho de 1996 e 1997, totalizando 8 coletas e 40 indivíduos diferentes amostrados para cada área.

Do total de folhas coletado, pertencentes ao ramo mais alto de cada árvore, parte (em média 120 folhas) foi herborizada no campo e parte ( $\pm 3 \mathrm{~g}$ ) foi congelada no campo, utilizando-se gelo seco, e mantida em laboratório em freezer $\left(-40^{\circ} \mathrm{C}\right)$ até a análise de taninos. Para cada indivíduo, a partir do material herborizado, foram sorteadas 40 folhas para análise de área foliar total e perdida por herbivoria. Em seguida, as 40 folhas foram novamente reunidas com o material herborizado restante, secas em estufa $\left(60^{\circ} \mathrm{C}\right)$, pulverizadas em moinho de lâmina e bola e então submetidas às análises de nitrogênio, fenóis totais, fibras e ligninas. 


\section{MÉTODOS}

\subsection{Nitrogênio Orgânico}

O conteúdo de nitrogênio orgânico foliar foi obtido através da digestão do material previamente seco e pulverizado em solução contendo ácido sulfúrico $(420 \mathrm{ml})$, peróxido de hidrogênio 30\% (350 $\mathrm{ml})$, sulfato de lítio $(14 \mathrm{~g})$ e selênio em pó $(0,42 \mathrm{~g})$. Em tubos de digestão, $0,27 \mathrm{~g}$ de material vegetal foi misturado a $8 \mathrm{ml}$ da solução digestora e mantido em bloco digestor a $350^{\circ} \mathrm{C}$ (Bataglia et al., 1983). O resíduo final, após resfriamento, foi submetido ao método MicroKjeldhal, no qual o produto obtido na digestão passa por um sistema de destilação a vapor com $10 \mathrm{ml}$ de ácido bórico 5\%, 2 gotas de indicador misto (verde de bromo cresol e vermelho de metila) e $15 \mathrm{ml}$ de hidróxido de sódio $18 \mathrm{~N}$, titulando-se o destilado com ácido clorídrico $0,1 \mathrm{~N}$ até o ponto de viragem do indicador.

O método baseia-se na conversão do nitrogênio orgânico em sulfato de amônio através da oxidação da matéria orgânica com ácido sulfúrico e peróxido de hidrogênio. No meio alcalino, a amônia é destilada e aprisionada na solução de ácido bórico e indicadores, sendo então titulada com ácido clorídrico padronizado, obtendo-se o resultado através do cálculo do volume de ácido clorídrico utilizado para atingir o ponto de viragem (Bataglia et al., 1983).

\subsection{Compostos Fenólicos Totais}

A extração de fenóis totais foi feita através do método modificado de Phillips \& Henshaw (1977), por meio do qual $1 \mathrm{~g}$ do material vegetal previamente seco e pulverizado foi submetido a extrações em $50 \mathrm{ml}$ de etanol $70 \%$. O material permanecia em banho-maria, $60^{\circ} \mathrm{C}$, durante 15 minutos. Após esse período, o sobrenadante era retirado para uma proveta, e o resíduo era submetido a nova extração adicionado-se mais $50 \mathrm{ml}$ de etanol. Esse procedimento era realizado até completar um volume final de $250 \mathrm{ml}$. Os extratos foram, então, submetidos a três métodos para a quantificação de fenóis totais. 
- Folin-Denis (FD): uma alíquota do extrato $(0,2 \mathrm{ml})$ foi misturada a 0,5 $\mathrm{ml}$ do reagente Folin-Denis (100 $\mathrm{g}$ de tungstato de sódio, $20 \mathrm{~g}$ de ácido fosfomolíbdico e $50 \mathrm{ml}$ de ácido fosfórico para cada litro de solução) e 1 $\mathrm{ml}$ de solução saturada de carbonato de sódio $(35 \mathrm{~g} / 100 \mathrm{ml}$ de água deionizada), completando-se com água deionizada até o volume final de $10 \mathrm{ml}$. A absorbância era lida em espectrofotômetro $(725 \mathrm{~nm})$ após 45 minutos (Folin \& Denis, 1912).

- Folin-Ciocalteu (FC): uma alíquota do extrato $(0,25 \mathrm{ml})$ foi misturada a $1 \mathrm{ml}$ do reagente Folin-Ciocalteu (100 g de tungstato de sódio, $25 \mathrm{~g}$ de ácido fosfomolíbdico, $50 \mathrm{ml}$ de ácido ortofosfórico e $100 \mathrm{ml}$ de ácido clorídrico para cada um litro de solução) e $3 \mathrm{ml}$ de solução saturada de carbonato de sódio ( $35 \mathrm{~g} / 100 \mathrm{ml}$ de água deionizada), completando-se com água deionizada até o volume final de $20 \mathrm{ml}$. A absorbância era lida em espectrofotômetro (760 nm) após 2 horas (Folin \& Ciocalteu, 1927; Waterman \& Mole, 1994).

- Azul da Prússia (AP): uma alíquota do extrato $(0,25 \mathrm{ml})$ foi misturada a $3 \mathrm{ml}$ dos reagentes de cloreto férrico $0,1 \mathrm{M}$ e de ferricianeto de potássio $0,008 \mathrm{M}$, completando-se com água deionizada até o volume final de $25 \mathrm{ml}$. A absorbância do extrato era lida em espectrofotômetro $(720 \mathrm{~nm})$ após $15 \mathrm{~min}$ (Waterman \& Mole, 1994).

Para a determinação da concentração de compostos fenólicos totais na amostra, utilizou-se, para os três métodos, uma curva de calibração preparada com soluções de ácido tânico a 10, 20, 30, 40, 50, $60,70,80,90$ e $100 \mu \mathrm{g} / \mathrm{ml}$. Os métodos baseiam-se no efeito redutor de hidroxilas fenólicas presentes no extrato. Portanto, muitas classes de substâncias são avaliadas, conseguindo-se uma medida relativa e não absoluta (McKey et al., 1978; Waterman \& Mole, 1994).

\subsection{Taninos Totais}

Do material vegetal congelado, $1 \mathrm{~g}$ foi triturado e homogeneizado em $5 \mathrm{ml}$ de metanol $50 \%$, deixado em repouso por 1 hora em temperatura ambiente e então submetido às metodologias de quantificação de taninos. 
- Difusão Radial (DR): foram preparadas placas de Petri de $8,5 \mathrm{~cm}$ de diâmetro contendo $12,5 \mathrm{ml}$ de gel de agarose tipo 1 (Sigma) $1 \%$ em tampão de ácido acético $(50 \mathrm{mM})$ /ácido ascórbico $(60 \mu \mathrm{M}) \mathrm{pH} 5,0$ e albumina de soro bovino fração V (Sigma) $0,1 \%$. As placas foram armazenadas a $4^{\circ} \mathrm{C}$ e orifícios de $4 \mathrm{~mm}$ de diâmetro, distanciados $1,5 \mathrm{~cm}$ entre si, foram feitos no gel com o auxílio de um furador de rolha. Alíquotas de $30 \mu \mathrm{l}$ do extrato foram depositadas nos orifícios. As placas foram vedadas com filme PVC transparente, cobertas com papel alumínio e incubadas a $30^{\circ} \mathrm{C}$ por $96-120$ horas. Durante esse período, os taninos presentes no extrato se difundem no gel e se complexam com a albumina, formando anéis de precipitado cujo diâmetro é proporcional à quantidade de taninos presentes na amostra. Após o período de incubação, os diâmetros dos anéis formados foram medidos com o auxílio de um paquímetro e comparados com os de uma curva de calibração preparada com soluções de ácido tânico a 0,25\%, 0,50\%, $0,75 \%, 1,0 \%, 1,50 \%$ e $2,0 \%$ (Hagerman, 1987).

- Método Colorimétrico (MC): uma alíquota do extrato $(1 \mathrm{ml})$ foi adicionada a $2 \mathrm{ml}$ de solução BSA $(0,1 \mathrm{mg} / \mathrm{ml}$ de albumina de soro bovino fração $\mathrm{V}$, cloreto de sódio $0,17 \mathrm{M}$ e tampão acetato $0,2 \mathrm{M} \mathrm{pH}$ $5,0)$ e submetida, após repouso de 15 minutos, à centrifugação a 5000 rpm por 30 minutos. Descartou-se o sobrenadante e o resíduo foi retomado em $4 \mathrm{ml}$ do reagente SDS (dodecilsulfato de sódio 1\%, trietanolamina 5\% e isopropanol 20\%) e $1 \mathrm{ml}$ de cloreto férrico 0,01 M. Após 30 minutos, foi lida a absorbância do extrato em espectrofotômetro (520 nm) (Waterman \& Mole, 1994).

Para a determinação da concentração de taninos totais presentes na amostra, foi utilizada uma curva de calibração preparada com soluções de ácido tânico a 0,025, 0,050, 0,075, 0,100, 0,125, 0,150, 0,175,0,200, 0,250 e $0,500 \%$.

\subsection{Fibras e Ligninas}

A quantidade de fibras e ligninas na amostra foi obtida através da extração do material solúvel em soluções ferventes de detergente 
(Hatfield et al., 1994). Do material vegetal seco e pulverizado, 0,5 g foi tratado com $50 \mathrm{ml}$ de solução de detergente neutro $(30 \mathrm{~g}$ de dodecilsulfato de sódio, $19 \mathrm{~g}$ de EDTA-Na, $7 \mathrm{~g}$ de tetraborato de sódio decaidratado, 4,5 $\mathrm{g}$ de fosfato de sódio dibásico e $10 \mathrm{ml}$ de 2-etoxietanol) em ebulição durante uma hora. Após esse período, a solução foi filtrada em cadinhos de Gooch e lavada com água fervente até total eliminação do detergente. $\mathrm{O}$ resíduo foi seco em estufa $\left(100^{\circ} \mathrm{C}\right)$ durante uma noite e pesado no dia seguinte, determinando-se a quantidade de fibra detergente neutra (NDF).

O resíduo da primeira extração foi então tratado com $100 \mathrm{ml}$ de solução de detergente ácido ( $20 \mathrm{~g}$ de CTBA em ácido sulfúrico $1 \mathrm{~N}$ ) a $100^{\circ} \mathrm{C}$ durante uma hora. Após esse período, a solução foi filtrada em cadinhos de Gooch e lavada com água fervente até total eliminação do detergente. $\mathrm{O}$ resíduo foi seco em estufa $\left(100^{\circ} \mathrm{C}\right)$ durante uma noite e pesado no dia seguinte, determinando-se a quantidade de fibra detergente ácida (ADF).

Por fim, o resíduo da segunda etapa foi tratado com ácido sulfúrico $12 \mathrm{M}$ durante 3 horas a temperatura ambiente. Após esse período, a solução foi filtrada em cadinhos de Gooch e lavada com água fervente até total eliminação do ácido. O resíduo foi seco em estufa $\left(100^{\circ}\right.$ C) durante uma noite, pesado, submetido à combustão $\left(450^{\circ} \mathrm{C}\right) \mathrm{e}$ novamente pesado, determinando-se a quantidade de lignina detergente ácida (ADL) pela diferença entre as duas pesagens.

\section{5. Área Foliar}

A quantificação da área foliar total foi obtida através do programa 'Leaf Area and Analysis Programme'. Cada folha foi colocada sobre uma placa de vidro sobre uma fonte de luz e focalizada por uma câmara filmadora acoplada ao microcomputador. A área pela qual a luz não atravessa é calculada pelo programa, correspondendo à área foliar real remanescente após herbivoria e considerada neste trabalho como área foliar com danos. Cobrindo-se as regiões da folha que foram perdidas por herbivoria, e fazendo-se nova leitura, obteve-se a área foliar considerada como total, ou seja, área que a folha apresentaria se não 
houvesse ocorrido herbivoria (Fig. 7). A diferença entre ambas revela a área foliar que foi perdida por ação da herbivoria. A presença de galhas em cada uma das 40 folhas por indivíduo analisado foi observada e quantificada através de simples contagem por folha analisada.

\section{ANÁLISES ESTATÍSTICAS}

Os resultados de porcentagem de herbivoria, nitrogênio, taninos, compostos fenólicos totais, fibras e ligninas foram tratados através de análises de variância univariada (ANOVA) com três fatores fixos, a fim de avaliar a significância das diferenças entre os valores obtidos nas três áreas de coleta e também entre as estações do ano e os anos de coleta em cada área amostrada. Para os resultados referentes ao número de galhas foi feita uma análise de variância univariada (ANOVA) com dois fatores fixos, área e ano de coleta, uma vez que não foi quantificado o número de galhas no verão do primeiro ano de coleta.

O método de comparações múltiplas de Tukey $(\alpha=0,05)$ foi utilizado para detectar se as médias encontradas para cada um dos doze tratamentos, ou seja, cada combinação de local, ano e estação do ano de coleta em relação ao número de parâmetros estudados, eram significativamente diferentes.

Para seleção de variáveis e ajuste de modelos, foram realizadas análises de regressão (método stepwise) e de resíduos para cada área amostrada, tentando estabelecer qual dos parâmetros estudados melhor explicaria a quantidade de herbivoria foliar sofrida em cada uma das três áreas amostradas.

$\mathrm{Na}$ confecção dos modelos, foram utilizadas as quarenta observações para cada uma das 7 variáveis explicativas: estação do ano e ano de coleta, nitrogênio, compostos fenólicos, taninos, fibras e ligninas. Para as variáveis teores de compostos fenólicos e taninos, foram utilizados apenas os resultados obtidos pelo método Folin-Denis e colorimétrico, respectivamente. Os dados de número de galhas não foram incluídos na análise por não haver o mesmo número de observações $(\mathrm{N}=30)$. 
A

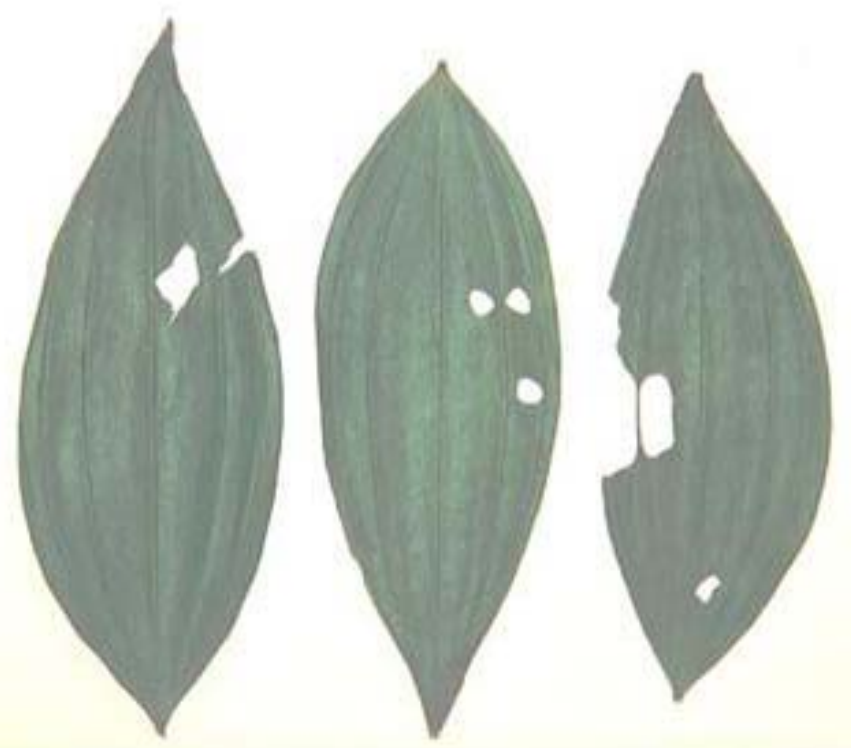

B

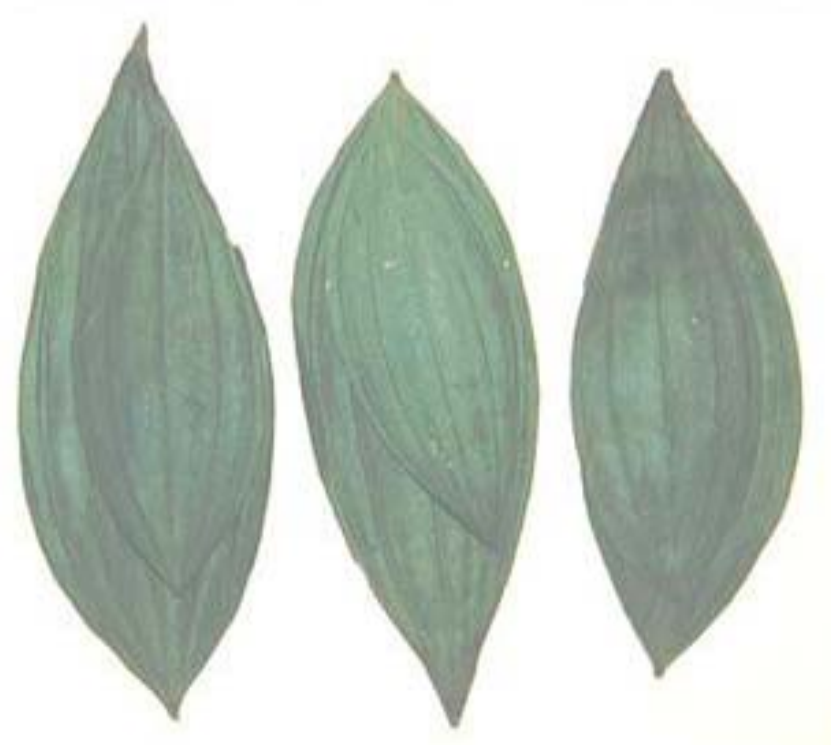

Fig. 7 - Análise de área foliar: A. área foliar real com danos por herbivoria; B. recurso para obtenção da área foliar sem danos. 
Todos os cálculos foram feitos através do programa estatístico Minitab (versão 10.1 para windows) e os métodos estatísticos utilizados podem ser encontrados em Neter et al. (1996). 


\section{RESULTADOS E DISCUSSÃO}

\section{EFEITO DA POLUIÇÃO NOS PARÂMETROS ESTUDADOS}

\subsection{Nitrogênio Orgânico}

Os indivíduos de Tibouchina pulchra das áreas poluídas do Vale do Rio Mogi e do Caminho do Mar apresentaram maiores concentrações foliares de nitrogênio quando comparadas com as observadas para os indivíduos da área de referência (Tab. 2). A análise estatística revelou uma diferença significativa $(\mathrm{p}<0,05)$ entre a média total dos valores encontrados nos pontos poluídos do Vale do Rio Mogi $(25,14 \mathrm{mg} / \mathrm{g})$ e Caminho do Mar $(23,17 \mathrm{mg} / \mathrm{g})$ quando comparados com os valores obtidos para o Vale do Rio Pilões $(19,86 \mathrm{mg} / \mathrm{g})(\mathrm{RP}<\mathrm{CM}=\mathrm{VM})$ (Fig. 8).

Tab. 2 - Concentração foliar média de nitrogênio orgânico (mg/g de peso seco) em indivíduos de Tibouchina pulchra $(\mathrm{N}=5)$ amostrados nas áreas do Vale do Rio Pilões (RP), Caminho do Mar (CM) e Vale do Rio Mogi (VM).

\begin{tabular}{ccccccccc}
\hline & \multicolumn{3}{c}{ RP } & & \multicolumn{2}{c}{ CM } & & \multicolumn{2}{c}{ VM } \\
\cline { 2 - 3 } \cline { 8 - 9 } \cline { 8 - 9 } \cline { 8 - 9 } Jan./96 & 14,11 & 0,91 & & 19,92 & 2,04 & & 20,35 & 1,42 \\
Fev./96 & 17,78 & 3,35 & & 22,46 & 2,13 & & 22,22 & 1,87 \\
Jun./96 & 18,41 & 1,46 & & 22,81 & 2,89 & & 21,94 & 1,33 \\
Jul./96 & 21,85 & 2,24 & & 24,39 & 1,30 & & 27,48 & 1,77 \\
Jan./97 & 22,50 & 3,76 & & 22,90 & 1,73 & & 29,18 & 0,71 \\
Fev./97 & 22,56 & 2,38 & & 24,87 & 1,93 & & 29,42 & 1,26 \\
Jun./97 & 20,93 & 2,77 & & 24,49 & 1,17 & & 25,03 & 0,76 \\
Jul./97 & 20,74 & 1,82 & & 23,47 & 2,83 & & 26,14 & 1,37 \\
\hline
\end{tabular}




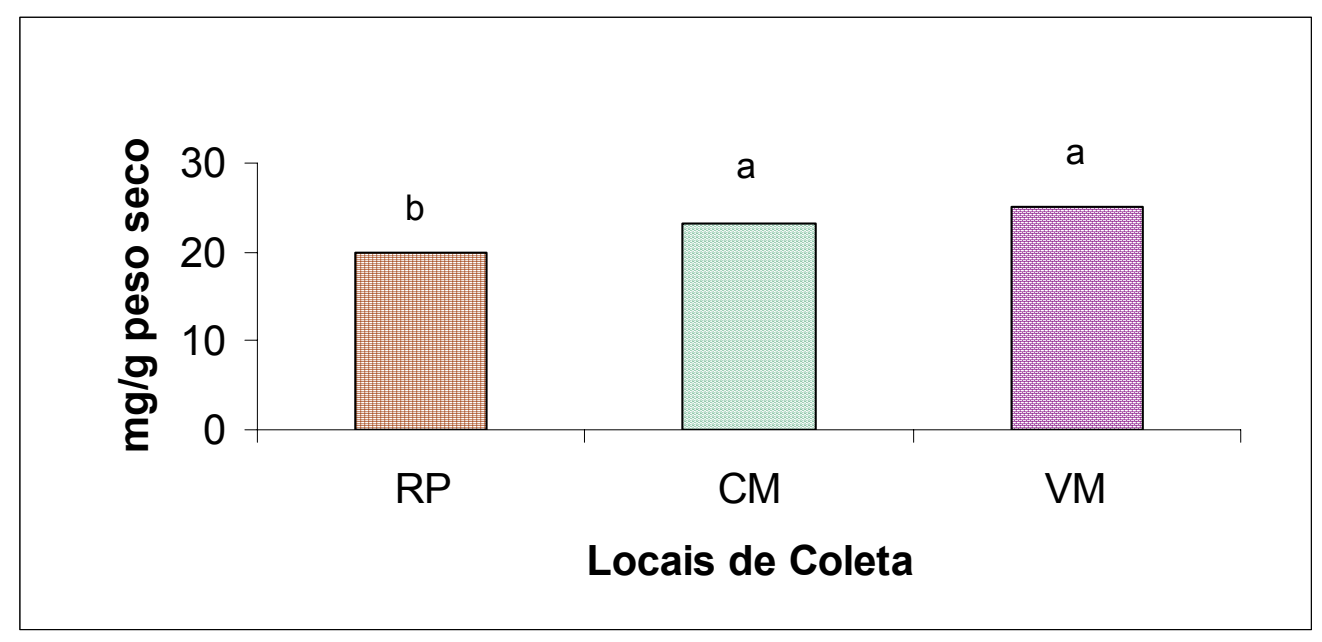

Fig. 8 - Concentração foliar média de nitrogênio $(\mathrm{mg} / \mathrm{g}$ peso seco) em indivíduos de Tibouchina pulchra $(\mathrm{N}=40)$ amostrados nas áreas do Vale do Rio Pilões (RP), Caminho do Mar (CM) e Vale do Rio Mogi $(\mathrm{VM})$. Letras diferentes correspondem a médias significativamente diferentes $(\mathrm{p}<0,05)$.

$\mathrm{Na}$ figura 9, estão representadas as médias das concentrações de nitrogênio por estação do ano e ano de coleta, as médias por estação do ano de coleta e as médias por ano de coleta. Notase que as concentrações de nitrogênio em folhas de Tibouchina pulchra na Serra do Mar variaram entre os períodos de amostragem, especialmente no Vale do Rio Mogi. Em todos os locais, não houve diferenças significativas entre os teores de nitrogênio nas amostras coletadas nos meses de verão e de inverno, porém, os valores encontrados em 1997 foram mais altos do que os registrados em 1996 para o Vale do Rio Pilões e do Rio Mogi. Essa variação de resultados entre os meses e estação do ano de coleta pode ser resultado de uma variação dos níveis de poluentes no ar em cada época de coleta, embora ainda não se encontram publicados os dados de concentrações de poluentes para o período de 1997.

O material estrutural das plantas pode conter até $5 \%(50 \mathrm{mg} / \mathrm{g})$ de nitrogênio, sendo essa quantidade dependente da espécie vegetal (influência genética), da idade, isto é, da etapa de desenvolvimento e 


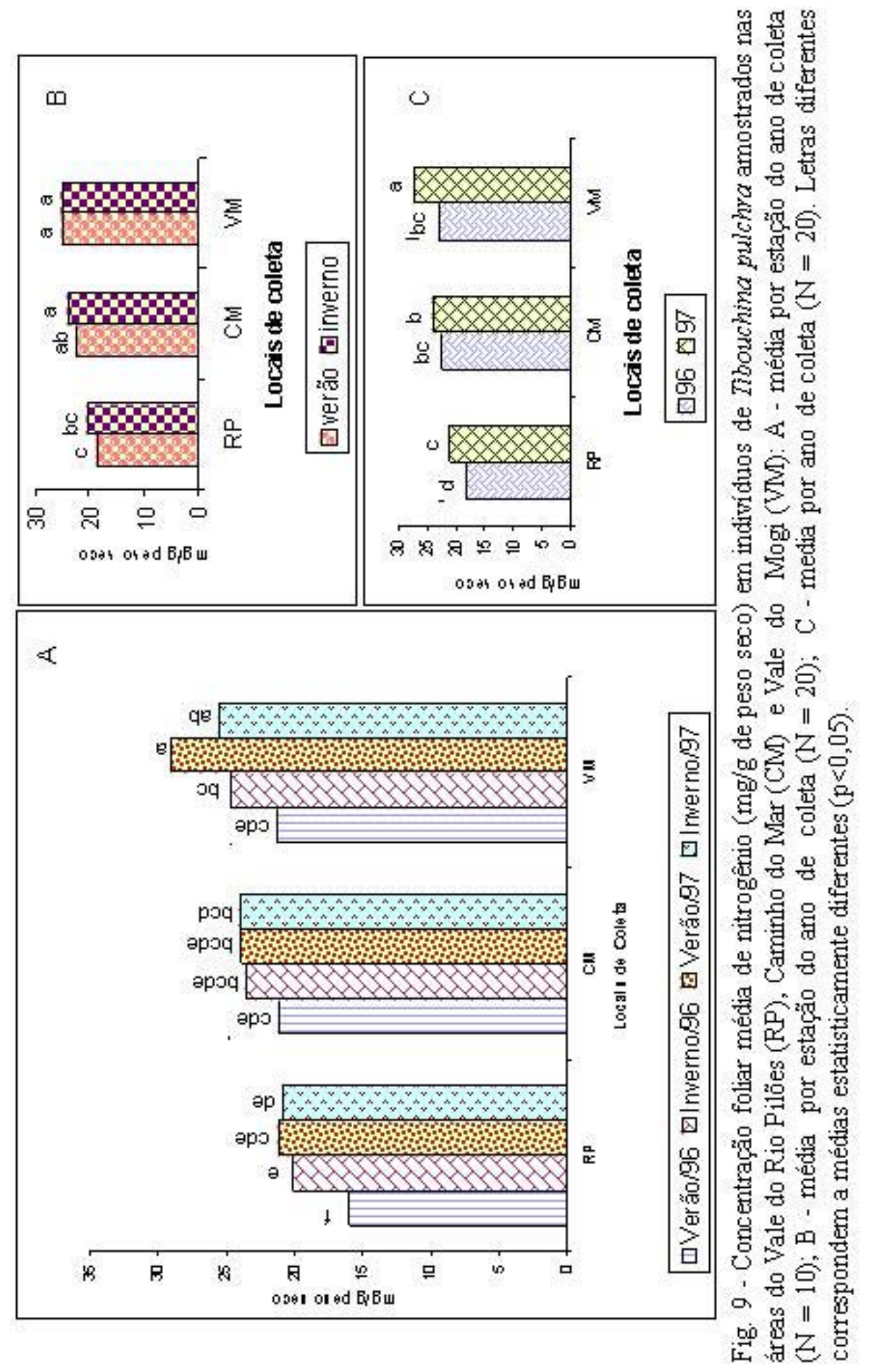


estado nutricional da planta, e do órgão em questão. O nitrogênio pode ocorrer basicamente em duas formas nos organismos vivos: a forma protéica e a não protéica. A forma não protéica inclui vários compostos de nitrogênio inorgânico, como nitratos e amônia, e os compostos de nitrogênio orgânico podem ser aminas, aminoácidos, vitaminas, pigmentos, etc. (Mattson, 1980).

Em estudos de biomonitoramento passivo com Tibouchina pulchra na Serra do Mar, nas mesmas áreas de amostragem, Domingos e colaboradores (1993) encontraram valores de nitrogênio foliar que variaram entre 22,38 mg/g para o Vale do Rio Pilões a $25,77 \mathrm{mg} / \mathrm{g}$ no Vale do Rio Mogi. Domingos (1998), encontrou maiores teores de nitrogênio nos indivíduos coletados no Vale do Rio Mogi, principalmente nos meses de maior pluviosidade, ou seja, durante o verão, fato não observado neste trabalho. Utilizando o biomonitoramento ativo e expondo mudas envasadas de Tibouchina pulchra à poluição atmosférica local, Pradella (1997) encontrou valores menores, que variaram entre $8 \mathrm{mg} / \mathrm{g}$ no Vale do Rio Pilões e $19 \mathrm{mg} / \mathrm{g}$ no Vale do Rio Mogi. Esses trabalhos revelaram que há um aumento de nitrogênio foliar quando a planta cresce ou é exposta à atmosfera poluída do Vale do Rio Mogi e do Caminho do Mar.

Estiarte e colaboradores (1994) observaram que há aumento nos teores de nitrogênio em folhas de Capsicum annuum L. tratadas com soluções contendo maiores concentrações de nitrogênio do que as tratadas com soluções com menores concentrações desse elemento, revelando a influência da quantidade de nitrogênio presente no meio na quantidade de nitrogênio orgânico encontrado na folha.

As plantas utilizam o nitrogênio ligado inorganicamente, retirando-o do solo nas formas de nitratos ou amônio, ou absorvendo-os diretamente através das folhas. O nitrogênio inorgânico é então incorporado nos grupos amino de compostos de carbono, gerando os aminoácidos, proteínas, ácidos nucléicos e outros compostos nitrogenados importantes para o metabolismo (Rowland et al., 1987a).

Segundo Port \& Thompson (1980, apud. Rowland et al., 1987a), o aumento de gases atmosféricos do tipo $\mathrm{NO}_{\mathrm{x}}$ emitidos pelas indústrias 
pode funcionar como uma forma extra de nitrogênio para a planta, aumentando assim a quantidade de nitrogênio foliar. $O$ acúmulo de nitrogênio total geralmente vem acompanhado por um aumento na assimilação de nitrogênio, ou seja, em plantas fumigadas com gases $\mathrm{NO}_{\mathrm{x}}$ geralmente é observado um aumento na atividade das enzimas envolvidas na redução de nitrato a amônia. $\mathrm{O}$ aumento de íons nitrato e nitrito nas folhas leva a um estímulo da atividade das enzimas nitrato e nitrito redutase, contribuindo assim para o aumento de nitrogênio reduzido e aminoácidos livres nas folhas (Smirnoff et al., 1984; Rowland et al., 1987a). Pearson \& Stewart (1993), relatam vários exemplos de aumento na atividade das enzimas nitrato e nitrito redutase em folhas de espécies vegetais fumigadas com gases $\mathrm{NO}_{\mathrm{x}}$, salientando que a assimilação desses gases, especialmente gases amônia, contribui para um aumento na quantidade de nitrogênio total na planta.

Os compostos de nitrogênio assim como os de enxofre nas formas de gases $\mathrm{NO}_{\mathrm{x}}$ e $\mathrm{SO}_{\mathrm{x}}$ possuem processos semelhantes de absorção e assimilação pela folha. Os gases são difundidos através do estômato onde reagem com a água extracelular da cavidade subestomática. Em meio aquoso, o composto $\mathrm{SO}_{2}$ é hidratado formando ácido sulfuroso $\left(\mathrm{H}_{2} \mathrm{SO}_{3}\right)$ que pode ser dissociado formando os íons $\mathrm{HSO}_{3}{ }^{-}, \mathrm{SO}_{3}{ }^{-2}$ e $\mathrm{SO}_{4}{ }^{-2}$ que são assimilados pela planta e podem ser refletidos em um aumento na folha de compostos sulfidrila (Malhotra \& Khan 1984; Anderson et al., 1987; Sheu, 1994). No caso de compostos de nitrogênio, o $\mathrm{NO}_{2}$ em meio aquoso é convertido em ácido nítrico $\left(\mathrm{HNO}_{3}\right)$ e nitroso $\left(\mathrm{HNO}_{2}\right)$ que por dissociação levam a formação dos íons $\mathrm{NO}_{3}{ }^{-}$e $\mathrm{NO}_{2}{ }^{-}$. Os íons nitrato e nitrito ativam as enzimas nitrato e nitrito redutase podendo estimular a síntese de aminoácidos e proteínas (Malhotra \& Khan 1984; Rowland et al. 1985, 1987a). Para Malhotra \& Khan (1984) as planta absorvem $\mathrm{NO}_{2}$ mais rapidamente do que NO uma vez que o NO é quase insolúvel em água difícultando sua conversão em ácido nitroso e conseqüente dissociação.

$\mathrm{O}$ aumento dos teores de nitrogênio foliar dos indivíduos amostrados nas regiões poluídas do Vale do Rio Mogi e Caminho do Mar pode ser devido ao acréscimo do elemento via poluição atmosférica 
ou via solo, que estaria funcionando como uma fonte adicional de nitrogênio para essas plantas. Segundo Alonso \& Godinho (1992) e Vasconcelos \& Abreu (1987), há a presença de $\mathrm{NO}_{2}$ principalmente no entorno de rodovias e na área de influência de refinarias de petróleo, por exemplo na área do Caminho do Mar. Amônia $\left(\mathrm{NH}_{3}\right)$ seria o poluente emitido principalmente pelas fábricas de fertilizantes, afetando especialmente a região do Vale do Rio Mogi. Segundo Jaeschke (1997), a área do Vale do Rio Mogi recebe forte influência de gases $\mathrm{NH}_{3}$ e $\mathrm{NO}_{\mathrm{x}}$, especialmente $\mathrm{NO}$, e também dos poluentes $\mathrm{SO}_{2}$ e fluoretos. Todos os gases ocorrem em concentrações variadas e dependentes do regime de ventos da região. Durante o dia as concentrações são mais altas devido à influência da brisa mar-continente, carregando os poluentes para dentro do vale e em direção à serra, enquanto durante a noite, por influência da brisa continente-mar, as massas de ar vão em direção ao oceano, diluindo as concentrações dos poluentes na região de Cubatão. Essas constantes mudanças das massas de ar aliadas às variações climáticas e aos níveis dos poluentes emitidos pelas indústrias podem ter causado as mudanças nas concentrações de nitrogênio foliar em Tibouchina pulchra observadas neste estudo.

Muitos trabalhos discutem ainda o efeito de outros tipos de poluentes ou de suas combinações nos níveis de nitrogênio foliar. Para Jones \& Coleman (1991), vários fatores de estresse induzem uma mobilização de nitrogênio nas plantas e aumentam as quantidades de aminoácidos, poli e diaminas e polipeptídeos de baixo peso molecular. Rowland e colaboradores (1987b) discutem a influencia não somente de $\mathrm{NO}_{2}$, mas também de ozônio e $\mathrm{SO}_{2}$, nos teores foliares de compostos nitrogenados, como o aumento no conteúdo de nitrogênio total e de aminoácidos, que pode ser causado por um aumento na degradação de proteínas, um aumento na assimilação de nitrato ou uma diminuição no transporte desses compostos para outras partes da planta. Segundo os autores, vários estudos demonstram que há uma diminuição no conteúdo total de proteínas nas folhas quando expostas à poluição atmosférica. Essa redução é atribuída a uma diminuição na síntese e/ou um aumento na taxa de degradação de proteínas que podem ser causadas pela ação de 
poluentes ou ainda condições bastante variadas de estresse. $\mathrm{O}$ mesmo pode ser visto para determinados aminoácidos, como exemplo prolina, metionina e histidina que aumentam em conteúdo nas folhas expostas tanto à presença de poluentes como sob condições de estresse (Rowland et al., 1987b; Jones \& Coleman, 1991; Lea et al., 1996).

Como em Cubatão há a presença de diversos poluentes em uma mesma área, formando misturas e combinações de poluentes, pode-se apenas delimitar áreas onde há a predominância de determinado poluente. Dessa forma, o aumento de nitrogênio foliar observado pode também ser devido a um efeito induzido por estresse por poluentes em geral, sendo uma resposta relacionada a presença de níveis fitotóxicos de poluição, não necessariamente relacionada à presença de um poluente em particular como gases $\mathrm{NO}_{\mathrm{x}}$.

\subsection{Compostos Fenólicos}

Ao contrário do nitrogênio, as concentrações foliares de compostos fenólicos totais, obtidas através das três diferentes metodologias, foram menores nas plantas expostas à ação da poluição (Tab. 3).

Embora com resultados quantitativamente diferentes, dependentes do método utilizado, as três metodologias de dosagem de compostos fenólicos totais mostraram uma mesma tendência de resultados: indivíduos das áreas mais poluídas do Caminho do Mar apresentaram concentrações foliares significativamente menores desses compostos do que os do Vale do Rio Mogi e estes, por sua vez, apresentaram concentrações menores do que as do Vale do Rio Pilões ( $R P>V M>C M$ ). A análise estatística mostrou uma diferença significativa $(p<0,05)$ entre os valores médios de compostos fenólicos totais encontrados no Vale do Rio Mogi e Caminho do Mar e os valores obtidos para a área de referência no Vale do Rio Pilões (Fig. 10). 
Tab. 3 - Concentração foliar média de compostos fenólicos totais (em \% de peso seco) em indivíduos de Tibouchina pulchra $(\mathrm{N}=5)$ amostrados nas áreas do Vale do Rio Pilões (RP), Caminho do Mar (CM) e Vale do Rio Mogi (VM), segundo as três metodologias utilizadas.

\begin{tabular}{|c|c|c|c|c|c|c|c|c|c|c|c|c|c|c|c|c|c|c|}
\hline & \multicolumn{6}{|c|}{ Folin-Denis } & \multicolumn{6}{|c|}{ Folin-Ciocalteu } & \multicolumn{6}{|c|}{ Azul da Prússia } \\
\hline & \multicolumn{2}{|c|}{$\mathrm{RP}$} & \multicolumn{2}{|c|}{$\mathrm{CM}$} & \multicolumn{2}{|c|}{$\mathrm{VM}$} & \multicolumn{2}{|c|}{$\mathrm{RP}$} & \multicolumn{2}{|c|}{$\mathrm{CM}$} & \multicolumn{2}{|c|}{$\mathrm{VM}$} & \multicolumn{2}{|c|}{$\mathrm{RP}$} & \multicolumn{2}{|c|}{$\mathrm{CM}$} & \multicolumn{2}{|c|}{ VM } \\
\hline & Média & Desvio & Média & Desvio & Média & Desvio & Média & Desvio & Média & Desvio & Média & Desvio & Média & Desvio & Média & Desvio & Média & Desvio \\
\hline Jan./96 & 7,28 & 0,69 & 3,95 & 1,74 & 5,62 & 0,43 & 4,18 & 0,51 & 2,32 & 1,07 & 3,09 & 0,25 & 14,81 & 2,13 & 6,38 & 4,46 & 11,47 & 0,76 \\
\hline Fev./96 & 4,81 & 0,95 & 2,57 & 1,10 & 3,15 & 0,70 & 3,04 & 0,46 & 1,75 & 0,68 & 2,10 & 0,43 & 14,27 & 3,00 & 7,29 & 3,94 & 10,80 & 2,22 \\
\hline Jun./96 & 8,21 & 1,14 & 2,62 & 0,94 & 7,15 & 0,86 & 5,19 & 0,58 & 1,95 & 0,83 & 4,68 & 1,24 & 15,92 & 3,65 & 2,61 & 1,23 & 14,10 & 2,31 \\
\hline Jul./96 & 4,36 & 1,36 & 1,59 & 1,01 & 2,96 & 0,92 & 3,11 & 2,37 & 1,29 & 1,25 & 2,26 & 1,40 & 18,49 & 4,65 & 4,22 & 2,77 & 12,83 & 2,90 \\
\hline Jan./97 & 3,73 & 0,91 & 3,00 & 0,80 & 2,51 & 0,51 & 1,73 & 0,53 & 1,56 & 0,45 & 1,24 & 0,20 & 13,95 & 4,13 & 8,61 & 3,47 & 9,65 & 1,75 \\
\hline Fev./97 & 2,78 & 0,57 & 1,17 & 0,31 & 2,64 & 0,28 & 1,45 & 0,279 & 0,70 & 0,17 & 1,40 & 0,13 & 13,27 & 2,86 & 5,53 & 0,835 & 12,83 & 1,07 \\
\hline Jun./97 & 2,72 & 0,37 & 1,03 & 0,34 & 2,26 & 0,47 & 1,46 & 0,21 & 0,63 & 0,20 & 1,24 & 0,20 & 10,59 & 1,50 & 3,37 & 1,43 & 9,41 & 2,14 \\
\hline Jul./97 & 3,30 & 0,39 & 1,29 & 0,38 & 2,67 & 0,26 & 1,84 & 0,23 & 0,77 & 0,13 & 1,49 & 0,13 & 15,63 & 1,75 & 4,30 & 1,01 & 12,81 & 1,06 \\
\hline
\end{tabular}




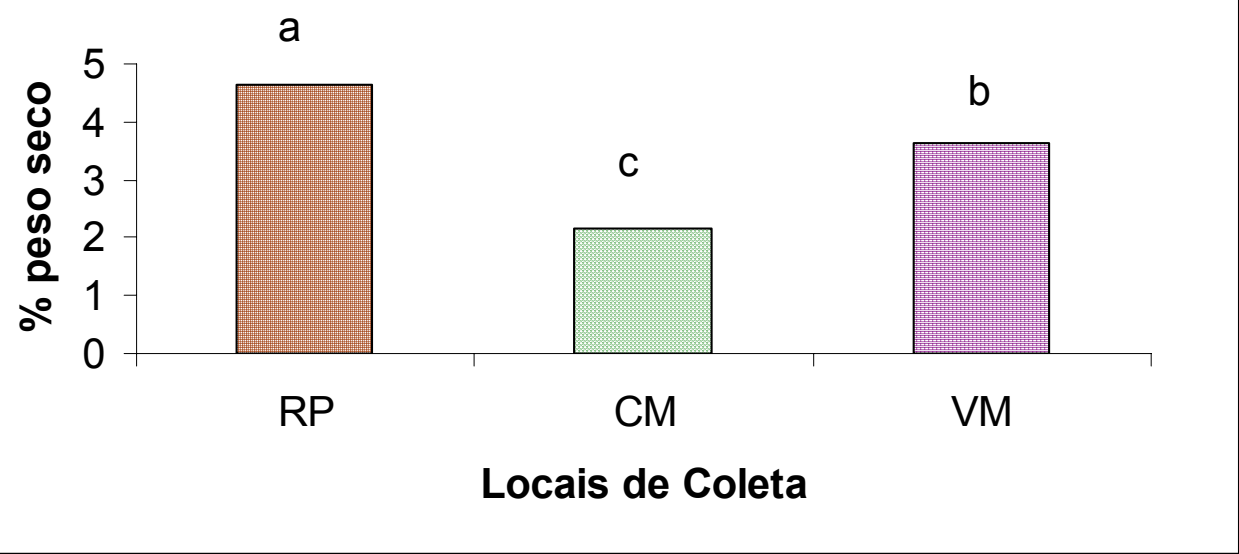

Fig. 10 - Concentração foliar média de compostos fenólicos (\% peso seco), obtida pelo método Folin-Denis, em indivíduos de Tibouchina pulchra $(\mathrm{N}$ = 40) amostrados nas áreas do Vale do Rio Pilões (RP); Caminho do Mar (CM) e Vale do Rio Mogi (VM). Letras diferentes correspondem a médias estatisticamente diferentes $(\mathrm{p}<0,05)$.

Os três métodos de análise de fenóis totais utilizados baseiam-se na quantificação da concentração de hidroxilas fenólicas presentes no extrato, que reduzem o reagente utilizado e, portanto, podem ter interferência de substâncias semelhantes. Os métodos são valiosos como uma avaliação das quantidades relativas de substâncias fenólicas, não das quantidades absolutas (McKey et al., 1978; Waterman \& Mole, 1994). A evolução nas três metodologias está relacionada ao aumento de sensibilidade do método, assim como à diminuição de interferências de substâncias capazes de serem oxidadas pelo reagente utilizado, como por exemplo as proteínas e o ácido ascórbico, que respondem de forma semelhante às substâncias fenólicas.

Para a análise estatística mais detalhada, foram utilizados os resultados obtidos apenas pelo método Folin-Denis, uma vez que as três metodologias mostraram a mesma tendência e por ser esse método o mais utilizado, segundo relatos da literatura.

$\mathrm{Na}$ figura 11 estão representadas as médias por estação do ano e ano de coleta, as médias por estação do ano de coleta e as médias por 


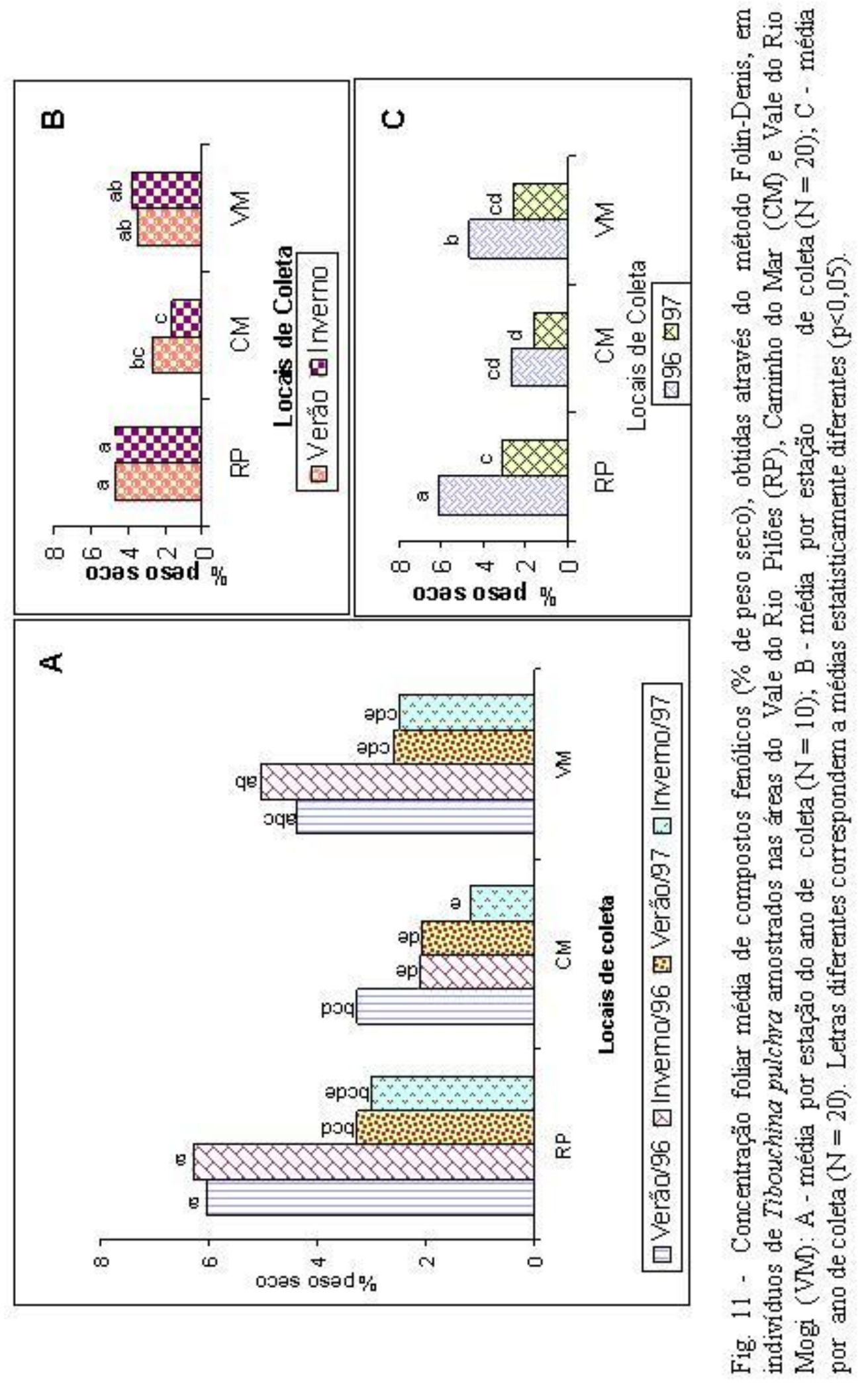


ano de coleta. Se as médias por estação do ano em cada ano de coleta, obtidas através do método Folin-Denis, forem avaliadas individualmente (Fig. 11A), observa-se apenas o efeito do ano, não havendo diferenças entre as estações do ano em que foram realizadas as coletas. Esses aspectos foram também evidenciados nas figuras 11B e 11C. Em 1996, o conteúdo de compostos fenólicos em plantas do Vale do Rio Pilões foi mais elevado do que nas plantas dos dois locais poluídos, enquanto em 1997, as médias obtidas para as plantas do Vale do Rio Pilões foram apenas significativamente superiores em relação às médias observadas para as plantas do Caminho do Mar. Nesta localidade, as médias para 1996 e 1997 foram, respectivamente, menores e iguais as médias do Vale do Rio Mogi. Essa variação de resultados entre os meses e estação de coleta pode ser resultado de uma variação dos níveis de poluentes no ar em cada época de coleta.

O termo compostos fenólicos tem sido utilizado para descrever o conjunto de substâncias que possuem um ou mais anéis aromáticos com um ou vários grupos hidroxílicos $(\mathrm{OH})$ ligados diretamente a eles (Harborne 1984; Appel, 1993; Waterman \& Mole, 1994). Constituem a classe de substâncias do metabolismo secundário mais distribuída entre as espécies vegetais, de grande importância ecológica por estar envolvida nas relações entre as plantas e herbívoros, patógenos e polinizadores (Summers \& Felton 1994; Waterman \& Mole, 1994). Polifenóis, como os taninos, funcionam como uma defesa contra herbívoros devido à habilidade desses compostos se complexarem com proteínas, resultando na destruição de funções enzimáticas, redução da digestibilidade de proteínas e da disponibilidade de aminoácidos (Summers \& Felton, 1994). Outros compostos fenólicos, como flavonóides, são importantes devido a coloração que proporcionam às pétalas, frutos, folhas e raízes, sendo importantes na atração de polinizadores (Harbone, 1982; Waterman \& Mole, 1994) além de funcionarem como redutores de herbivoria (Harborne, 1988). Como exemplos de substâncias fenólicas, estão listados na tabela 4 os principais grupos de fenóis e os compostos a eles pertencentes. 
Tab. 4 - Principais grupos de substâncias fenólicas e suas características (baseado em Harborne, 1980 e 1984). (C 6 ) núcleo aromático; $\left(\mathrm{C}_{\mathrm{n}}\right)$ número de carbonos na cadeia lateral.

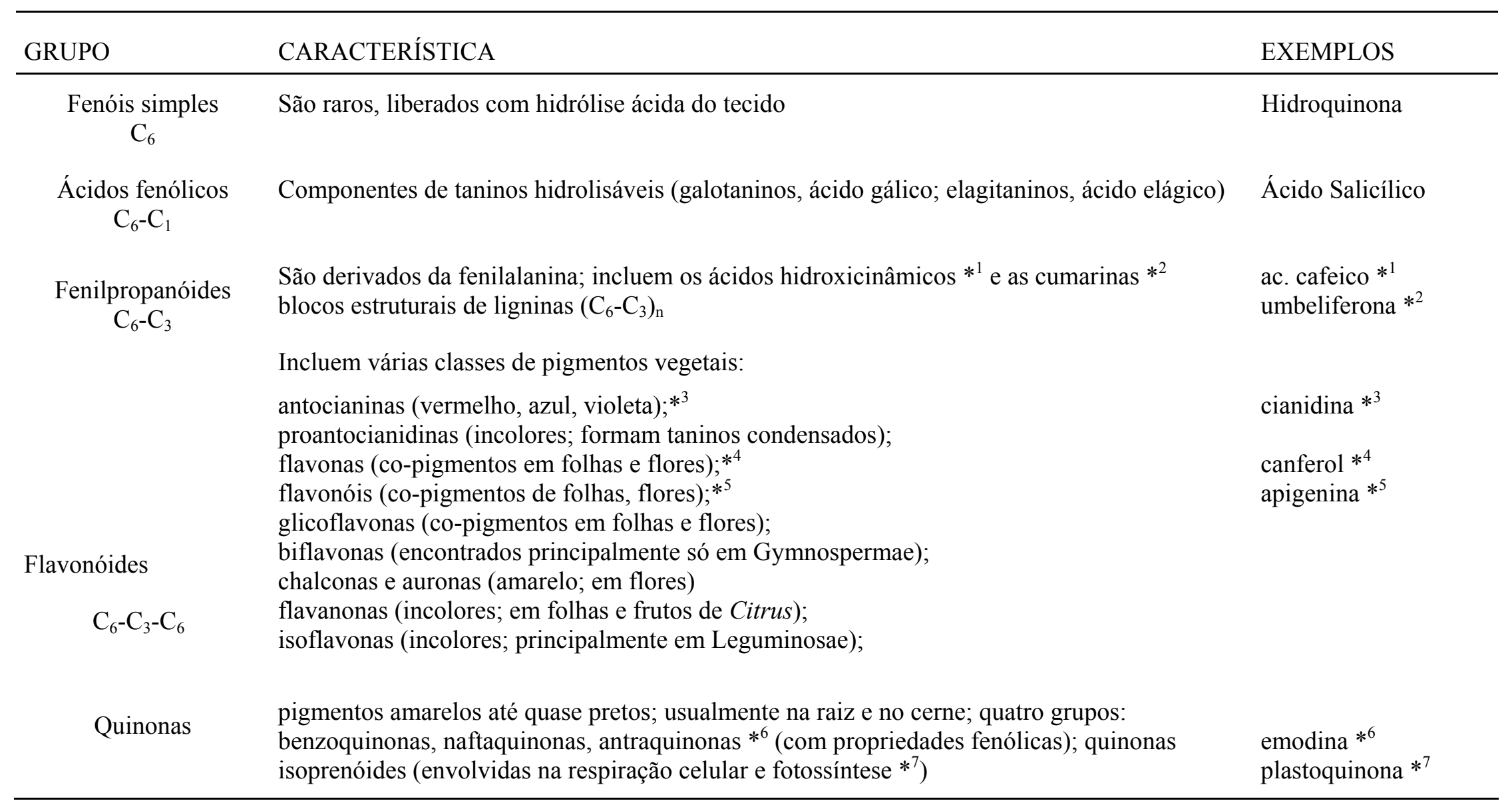


Praticamente quase todos os compostos fenólicos, como flavonóides, taninos, ligninas, e alguns alcalóides, são formados via metabolismo do ácido chiquímico e da fenilalanina, ambos derivados do metabolismo de açúcares (Kicinski et al., 1988; Herrmann, 1995). Alterações nas quantidades e tipos de açúcares podem causar aumento ou diminuição na síntese e degradação da maioria dos metabólitos secundários. Alguns autores vêm relacionando a diminuição dos teores de alguns metabólitos secundários, por exemplo os compostos fenólicos, à influência da poluição no metabolismo de açúcares. Segundo Jones \& Coleman (1991), a poluição atmosférica pode reduzir o ganho de carbono, diminuindo a relação entre carbono e nitrogênio da planta, podendo haver uma redução nos teores de compostos secundários e aumento nos dos compostos nitrogenados.

Katoh e colaboradores (1989a) relatam que o ozônio também leva a uma redução nos níveis de glicose, alterando o metabolismo do ácido chiquímico e reduzindo os teores de compostos fenólicos em Cryptomeria japonica. Kainulainen et al. (1995) verificaram que há diminuição na quantidade de glicose e frutose e aumento na quantidade de sacarose nas mudas de Pinus sylvestris e Picea abies expostas a determinadas concentrações de $\mathrm{SO}_{2}$, levando à redução nas quantidades de compostos fenólicos. Fialho \& Bücker (1996) observaram em Populus nigra uma queda na quantidade de amido foliar e carboidratos não-estruturais (rafinose, sacarose, glicose e frutose) após 20 dias de exposição a concentrações de $\mathrm{O}_{3}$ e $\mathrm{SO}_{2}$ separadamente e em combinações dos dois poluentes, indicando que há efeito da concentração desses poluentes no metabolismo de açúcares.

Kicinski e colaboradores (1988) relatam que a exposição de plantas a concentrações de $\mathrm{O}_{3}$ e $\quad \mathrm{SO}_{2}$ pode resultar em uma mudança na permeabilidade da folha modificando a absorção de gases, entre eles poluentes, levando a uma senescência prematura, na qual se observa o aumento da atividade catabólica com acúmulo de amido, aumento na síntese de polifenóis, degradação de cloroplastos e clorofilas e redução na taxa fotossintética. Pradella (1997), em estudo com mudas de Tibouchina pulchra expostas nas mesmas três áreas utilizadas neste trabalho, observou que as plantas das áreas mais poluídas do Caminho do Mar e Vale do Rio 
Mogi apresentam diminuição na capacidade fotossintética quando comparadas com as plantas do Vale do Rio Pilões, que apresentaram $40 \%$ a mais de fotossíntese líquida. A queda na fotossíntese líquida levaria a uma redução na quantidade de açúcares sintetizados e, conseqüentemente, diminuição de produtos formados via metabolismo de açúcares, como a maioria dos compostos fenólicos. Os danos nos processos fotoquímicos da fotossíntese, que ocorrem nas áreas poluídas do Vale do Rio Mogi e Caminho do Mar, podem ter resultado nas alterações na quantidade de compostos formados via metabolismo primário e secundário observadas no presente estudo.

Malhotra \& Khan (1984) discutem ainda o efeito do ozônio na atividade das enzimas envolvidas no metabolismo fenólico, como a fenilalanina amonialiase (PAL), polifenoloxidase e peroxidase, havendo a tendência a um aumento na atividade dessas enzimas, levando a um estímulo na oxidação de fenóis, gerando quinonas e acúmulo de produtos de polimerização. Domingos et al. (1993), Klumpp et al. (1997) e Domingos (1998) encontraram maior atividade da peroxidase nos indivíduos de Tibouchina pulchra, Cecropia glazioui e Psidium guajava expostos nas áreas do Caminho do Mar e Vale do Rio Mogi. Esses resultados podem indicar um estresse oxidativo resultante de alteração no sistema enzimático de controle da síntese de fenóis, levando às mudanças nos teores de compostos fenólicos dos indivíduos de Tibouchina pulchra dessas áreas.

\subsection{Taninos Totais}

Os teores de taninos foliares totais, em ambas metodologias utilizadas, foram significativamente menores $(p<0,05)$ nas plantas expostas à ação da poluição no Vale do Rio Mogi e no Caminho do Mar quando comparados aos valores obtidos para a área de referência no Vale do Rio Pilões (Tab. 5). As concentrações de taninos nas plantas do Caminho do Mar, por sua vez, foram menores do que as registradas nas árvores do Vale do Rio Mogi (RP $>\mathrm{VM}>\mathrm{CM})$ (Fig. 12). 
Tab. 5 - Concentração foliar média de taninos (\% de peso seco) em indivíduos de Tibouchina pulchra $(\mathrm{N}=5)$ amostrados nas áreas do Vale do Rio Pilões (RP), Caminho do Mar (CM) e Vale do Rio Mogi (VM), segundo duas metodologias de análise.

\begin{tabular}{|c|c|c|c|c|c|c|c|c|c|c|c|c|}
\hline & \multicolumn{6}{|c|}{ Colorimétrico } & \multicolumn{6}{|c|}{ Difusão Radial } \\
\hline & \multicolumn{2}{|c|}{ RP } & \multicolumn{2}{|c|}{$\mathrm{CM}$} & \multicolumn{2}{|c|}{ VM } & \multicolumn{2}{|c|}{$\mathrm{RP}$} & \multicolumn{2}{|r|}{$\mathrm{CM}$} & \multicolumn{2}{|c|}{ VM } \\
\hline & Média & Desvio & Média & Desvio & Média & Desvio & Média & Desvio & Média & Desvio & Média & Desvio \\
\hline Jan./96 & 1,10 & 0,29 & 0,19 & 0,19 & 0,33 & 0,16 & 0,23 & 0,03 & 0,16 & 0,02 & 0,17 & 0,02 \\
\hline Fev./96 & 1,38 & 0,45 & 0,98 & 0,49 & 0,51 & 0,31 & 0,23 & 0,02 & 0,19 & 0,02 & 0,18 & 0,01 \\
\hline Jun./96 & 0,67 & 0,30 & 0,14 & 0,12 & 0,26 & 0,21 & 0,12 & 0,01 & 0,10 & 0,00 & 0,13 & 0,02 \\
\hline Jul./96 & 0,94 & 0,43 & 0,10 & 0,06 & 0,75 & 0,52 & 0,19 & 0,03 & 0,10 & 0,01 & 0,17 & 0,01 \\
\hline Jan./97 & 0,45 & 0,25 & 0,11 & 0,08 & 0,50 & 0,32 & 0,17 & 0,04 & 0,09 & 0,01 & 0,14 & 0,03 \\
\hline Fev./97 & 0,63 & 0,26 & 0,34 & 0,28 & 0,68 & 0,16 & 0,30 & 0,03 & 0,14 & 0,01 & 0,15 & 0,01 \\
\hline Jun./97 & 0,55 & 0,44 & 0,07 & 0,12 & 0,45 & 0,50 & 0,16 & 0,04 & 0,11 & 0,00 & 0,15 & 0,03 \\
\hline Jul./97 & 0,79 & 0,35 & 0,15 & 0,07 & 0,36 & 0,19 & 0,14 & 0,01 & 0,11 & 0,00 & 0,16 & 0,02 \\
\hline
\end{tabular}




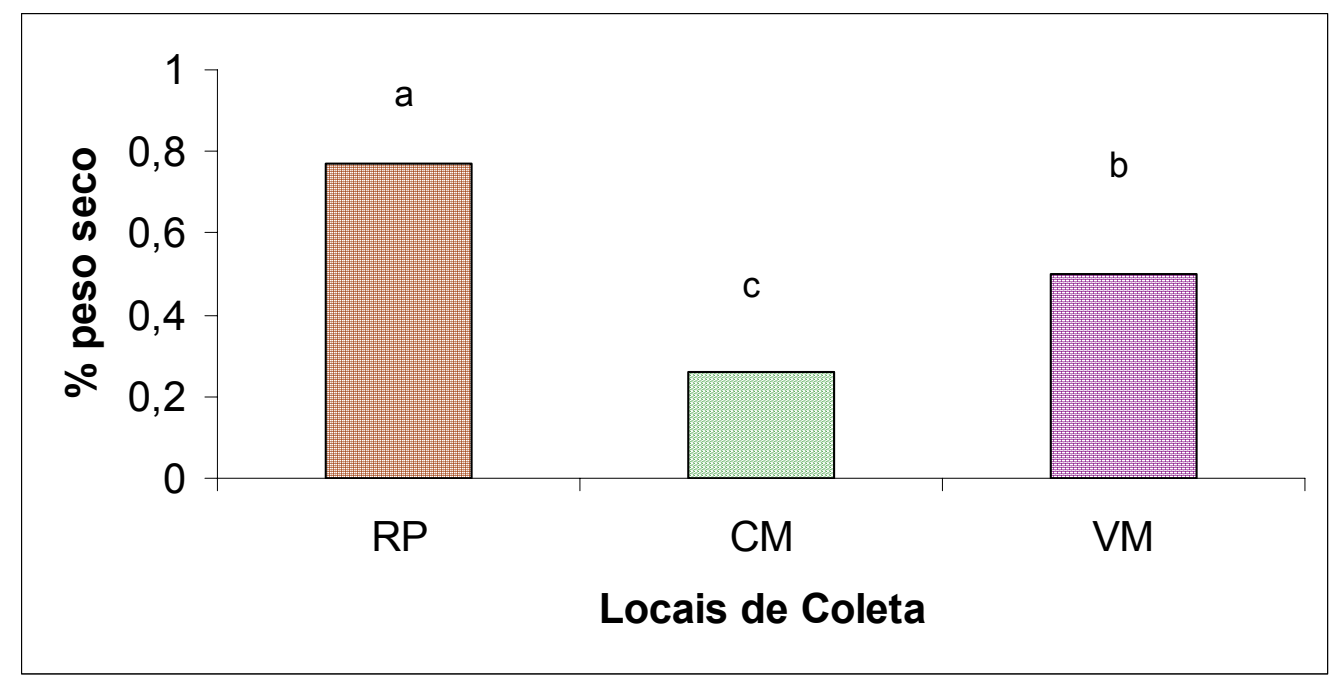

Fig. 12 - Concentração foliar média de taninos totais (\% peso seco), obtida pelo método colorimétrico, em indivíduos de Tibouchina pulchra $(\mathrm{N}=40)$ amostrados nas áreas do Vale do Rio Pilões (RP), Caminho do Mar (CM) e Vale do Rio Mogi (VM). Letras diferentes correspondem a médias estatisticamente diferentes $(\mathrm{p}<0,05)$.

As duas metodologias empregadas para dosagem de taninos, embora com resultados numericamente diferentes, mostraram a mesma tendência de diminuição quantitativa de taninos nas plantas dos locais poluídos, adotando-se, assim, para análise estatística mais detalhada, os resultados obtidos através do método colorimétrico por ser uma metodologia mais confiável (Waterman \& Mole, 1994).

Segundo Swain (1979), os valores de taninos foliares variam geralmente entre 0,5 e $10 \%$ do peso seco, embora algumas espécies possam apresentar valores superiores, como Geranium sanguineum, que possui $20 \%$ do peso seco de sua folha representada por taninos. Os valores encontrados através do método colorimétrico para Tibouchina pulchra na área do Vale do Rio Pilões encontram-se dentro da margem dos valores considerados normais, entretanto, os valores obtidos nas plantas das áreas poluídas encontram-se abaixo dos valores esperados.

Na figura 13 estão representados os valores médios por estação do ano em cada ano de coleta, os valores médios por estação do ano de coleta e os valores médios por ano de coleta. Para o parâmetro teor de taninos não foi observado um efeito claro da estação do ano ou do ano de coleta nos valores médios encontrados nas três áreas. Nítida diferença 


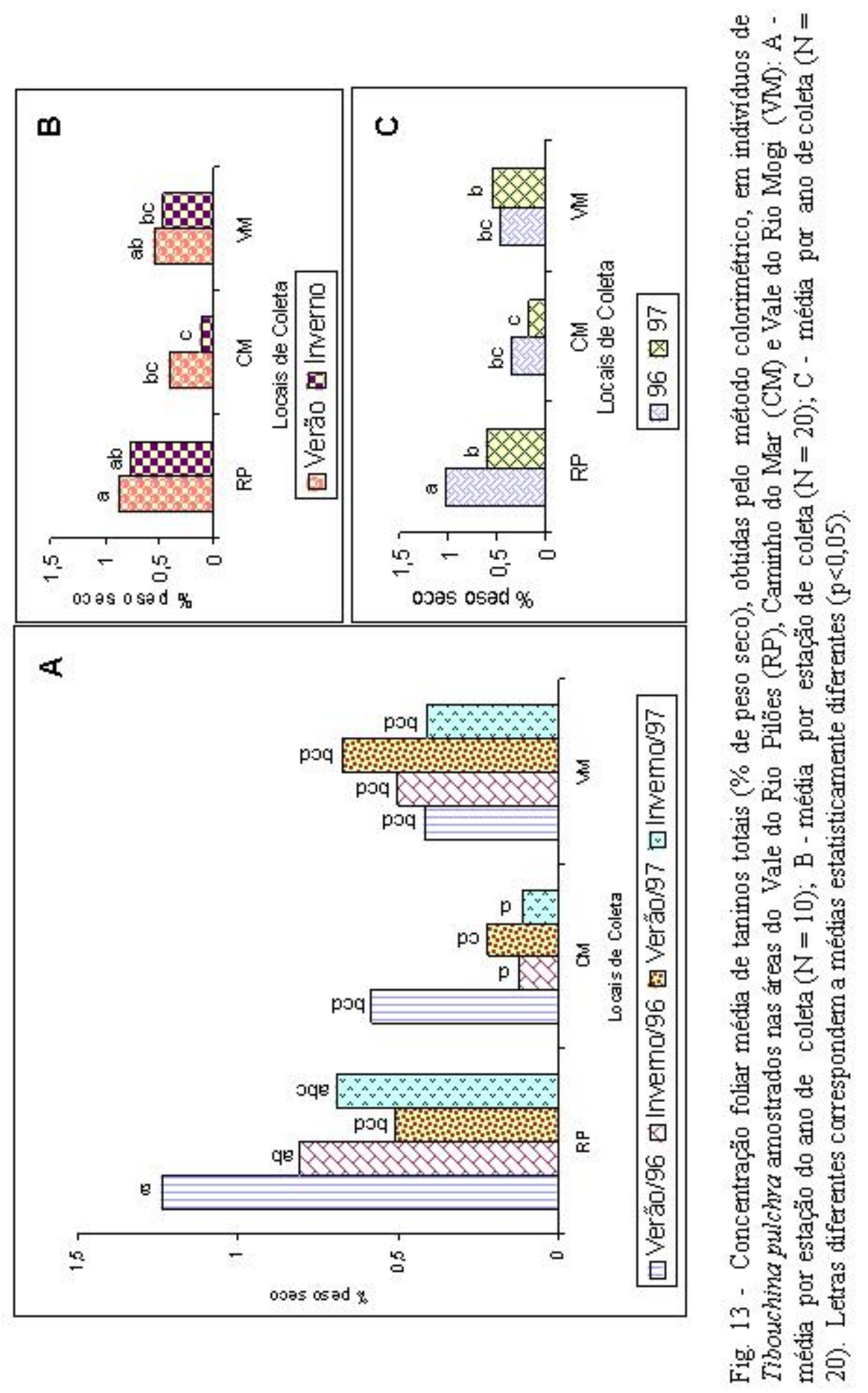


entre os resultados para cada local somente foi encontrada quando são consideradas as médias gerais como representado na figura 12 .

O termo tanino surgiu no final do século XVIII para definir substâncias presentes em extratos vegetais aquosos com a capacidade de transformar pele animal em couro. Além da função tanante, também afetam a palatabilidade de vinhos, frutas e verduras e são utilizados como adstringentes em preparações farmacêuticas (Swain, 1979; Mole \& Waterman, 1987). Abrange vários grupos de substâncias que apresentam certas propriedades químicas e físicas em comum, mas muitas vezes sem relações estruturais. São geralmente definidos como polímeros solúveis em água, ricos em grupos fenólicos e capazes de se combinarem com proteínas e outros polímeros, como pectina e celulose, formando precipitados tanino-proteína ou tanino-polímero insolúvel em água (Hagerman \& Butler, 1989).

A maioria das classificações químicas divide estruturalmente os taninos em duas classes, os taninos hidrolisáveis e os condensados, que diferem entre si não somente no tamanho molecular, mas também na presença ou não de glicose como parte da sua estrutura química. Os taninos hidrolisáveis, que podem ser decompostos química ou enzimaticamente, consistem de carboidrato com grupamentos hidroxílicos esterificados com ácido gálico ou elágico, e por isso são também chamados de galotaninos e elagitaninos. Os taninos condensados são formados pela condensação de catequinas ou proantocianidinas, não apresentam açúcares na sua estrutura e têm maior peso molecular. Ambos os tipos de taninos são importantes nas relações inseto-planta uma vez que se complexam a proteínas, reduzem a atividade enzimática e tornam os tecidos menos palatáveis aos herbívoros (Harborne, 1980; Beart et al., 1985; Hagerman \& Butler, 1989). As metodologias utilizadas neste trabalho quantificaram os teores de taninos totais, sem distinção entre hidrolisáveis e condensados.

Os taninos podem ser tóxicos e ter ação minimizadora da herbivoria para um herbívoro em particular (Coley, 1986). Alguns trabalhos admitem a presença de taninos como uma forma de estoque de, por exemplo glicídeos, como sugerido por Dement \& Mooney (1974, 
apud Coley, 1986) em Heteromeles arbutifolia. Sabe-se também que são importantes na defesa da planta contra fitopatógenos, pois são capazes não apenas de se complexarem a ácidos nucléicos, proteínas e polissacarídeos dos tecidos foliares como também previnem a quebra desses polímeros por fungos e bactérias, inibindo uma série de enzimas essenciais ao ataque desses patógenos, afetando todo o metabolismo do organismo e impedindo sua divisão celular (Swain, 1979).

Embora ainda haja controvérsias a respeito da ação de taninos diretamente sobre os insetos, há evidências de que eles podem se ligar às proteínas, formando precipitados no tubo digestivo do animal, diminuindo assim a sua disponibilidade. Vários experimentos com bovinos e ovinos vêm demonstrando a preferência desses herbívoros por certos tipos de alimento de acordo com a quantidade de taninos presente (Swain, 1979). Estudos com macacos (Oates et al., 1977 apud Swain, 1979), gorilas (Harborne, 1977 apud Swain 1979) e insetos (Rhoades, 1979 apud Swain, 1979) mostraram que concentrações foliares de taninos maiores que $2 \%$ do peso seco são capazes de inibir a herbivoria por esses animais.

Assim como a maioria dos compostos fenólicos, os taninos também são sintetizados nas folhas a partir de glicose, via metabolismo do ácido chiquímico (Swain, 1979). Dessa forma, a quantidade de taninos também é influenciada se ocorrer alterações nas quantidades de açúcares disponíveis para a utilização nessa via. Katoh e colaboradores (1989b) observaram uma redução na quantidade de taninos foliares em Cryptomeria japonica associada a presença de poluentes, principalmente $\mathrm{SO}_{2}$. Verificaram que há uma redução no potencial fotossintético da planta quando exposta à poluição e, se essa inibição da fotossíntese for contínua, a maior parte da glicose livre será consumida principalmente nos processos de crescimento e metabolismo primário, afetando assim a síntese de compostos secundários. Katoh e colaboradores (1989a) verificaram uma forte correlação negativa entre a quantidade de enxofre foliar e as quantidades de glicose e ácido chiquímico, assim como uma correlação positiva entre a quantidade de glicose e derivados chiquímicos em Cryptomeria japonica, evidenciando que há uma 
influência da quantidade de glicose na quantidade de derivados chiquímicos e uma influência deste na quantidade de taninos e compostos fenólicos totais.

Cabe lembrar que Pradella (1997), em estudo com mudas de Tibouchina pulchra expostas nas mesmas três áreas utilizadas neste trabalho, observou que as plantas das áreas poluídas do Caminho do Mar e Vale do Rio Mogi apresentam diminuição na capacidade fotossintética em relação as do Vale do Rio Pilões, que apresentaram $40 \%$ a mais de fotossíntese líquida. A queda na fotossíntese líquida levaria a uma redução na quantidade de açúcares sintetizados e, conseqüentemente, diminuição de produtos formados via metabolismo de açúcares, como a maioria dos compostos fenólicos, entre eles os taninos. Os danos nos processos fotoquímicos da fotossíntese, que ocorrem nas áreas poluídas do Vale do Rio Mogi e Caminho do Mar, podem ter resultado nas alterações na quantidade de taninos observadas no presente estudo.

\subsection{Fibras e Ligninas}

$\mathrm{Na}$ tabela 6 estão listadas as médias dos valores encontrados em cada período de coleta para as três áreas amostradas. Foi observado que os indivíduos das áreas poluídas do Vale do Rio Mogi e do Caminho do Mar apresentaram maiores conteúdos foliares médios de fibras do que os indivíduos do Vale do Rio Pilões ( $\mathrm{VM}=\mathrm{CM}>\mathrm{RP}$ ) (Fig. 14A). Para os valores de ligninas, foi observado que os indivíduos do Vale do Rio Pilões apresentam menores concentrações de ligninas do que os indivíduos do Caminho do Mar, mas maiores quando comparados com os indivíduos do Vale do Rio Mogi (CM $>$ RP $>$ VM) (Fig. 14B).

Nas figuras 15 e 16 estão representados os valores médios por estação do ano e ano de coleta, os valores médios por estação do ano de coleta e os valores médios por ano de coleta de fibras e ligninas foliares nas três áreas de amostragem. 
Tab. 6 - Porcentagem média de fibras e ligninas foliares (\% de peso seco) em indivíduos de Tibouchina pulchra $(\mathrm{N}=5)$ amostrados nas áreas do Vale do Rio Pilões (RP), Caminho do Mar (CM) e Vale do Rio Mogi (VM).

\begin{tabular}{|c|c|c|c|c|c|c|c|c|c|c|c|c|}
\hline & \multicolumn{6}{|c|}{ Fibras } & \multicolumn{6}{|c|}{ Ligninas } \\
\hline & \multicolumn{2}{|c|}{$\mathrm{RP}$} & \multicolumn{2}{|c|}{$\mathrm{CM}$} & \multicolumn{2}{|c|}{ VM } & \multicolumn{2}{|c|}{$\mathrm{RP}$} & \multicolumn{2}{|c|}{$\mathrm{CM}$} & \multicolumn{2}{|c|}{ VM } \\
\hline & Média & Desvio & Média & Desvio & Média & Desvio & Média & Desvio & Média & Desvio & Média & Desvio \\
\hline Jan./96 & 36,43 & 1,60 & 42,96 & 2,08 & 35,97 & 1,72 & 5,85 & 0,49 & 11,30 & 3,75 & 5,36 & 0,68 \\
\hline Fev./96 & 37,36 & 1,27 & 38,87 & 2,84 & 32,00 & 1,81 & 8,65 & 3,28 & 11,44 & 4,80 & 7,80 & 3,57 \\
\hline Jun./96 & 34,59 & 6,38 & 43,53 & 2,76 & 39,31 & 1,52 & 8,42 & 3,49 & 15,33 & 3,25 & 7,38 & 2,55 \\
\hline Jul./96 & 39,47 & 2,18 & 46,88 & 4,81 & 41,36 & 1,43 & 6,29 & 0,73 & 9,43 & 3,57 & 6,53 & 0,73 \\
\hline Jan./97 & 38,56 & 2,65 & 41,18 & 2,09 & 47,22 & 9,97 & 8,50 & 4,40 & 8,69 & 2,12 & 6,61 & 0,70 \\
\hline Fev./97 & 41,28 & 0,68 & 45,11 & 5,99 & 64,90 & 1,94 & 14,52 & 1,26 & 12,38 & 6,91 & 8,25 & 0,63 \\
\hline Jun./97 & 41,08 & 0,83 & 55,88 & 5,09 & 61,90 & 3,38 & 12,28 & 0,86 & 15,83 & 3,85 & 10,94 & 3,15 \\
\hline Jul./97 & 43,46 & 2,50 & 52,88 & 3,10 & 65,38 & 1,25 & 15,33 & 3,79 & 19,42 & 4,23 & 11,16 & 2,91 \\
\hline
\end{tabular}




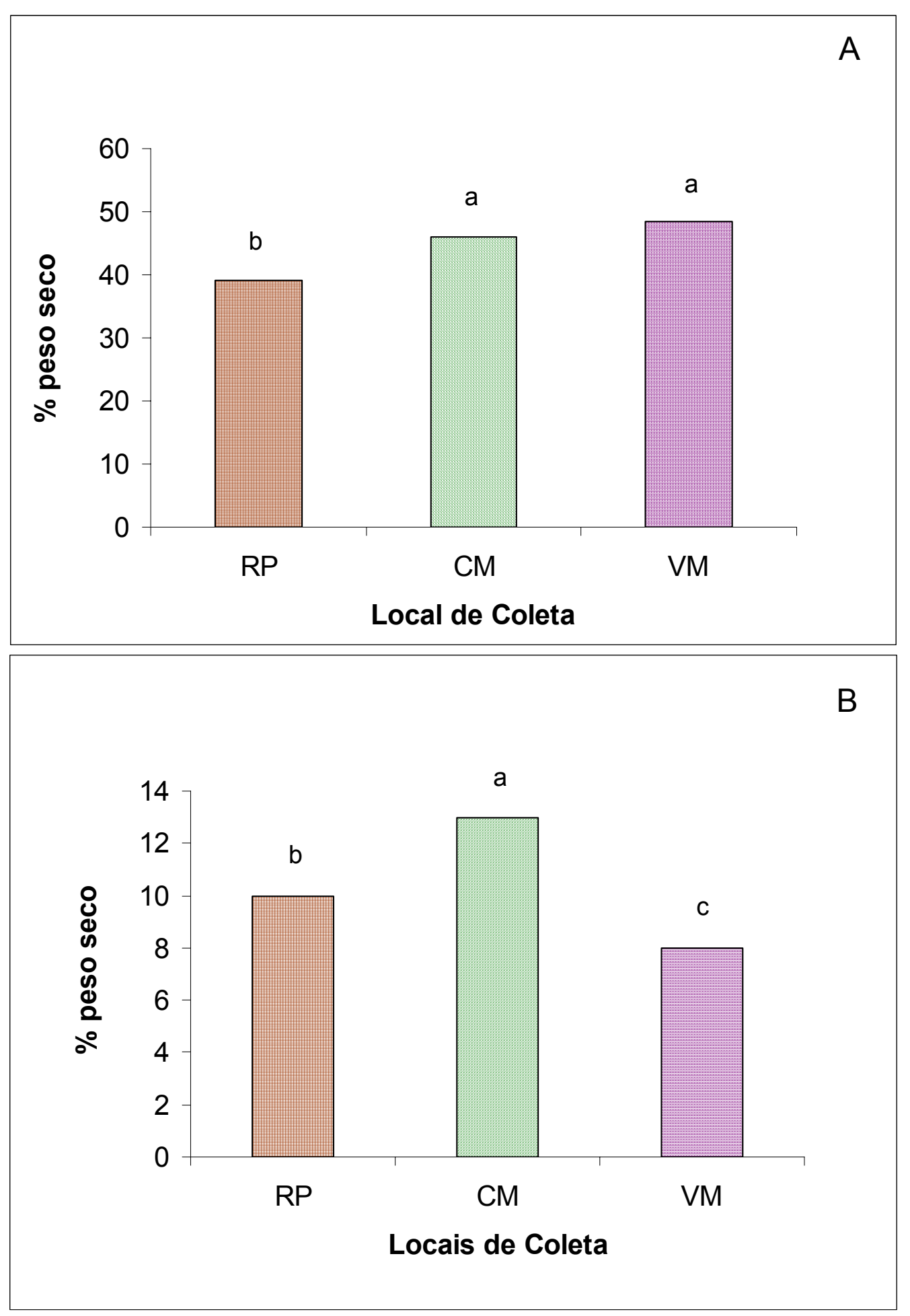

Fig. 14 - Concentração média de fibras (A) e ligninas (B) foliares (\% peso seco) em indivíduos de Tibouchina pulchra $(\mathrm{N}=40)$ amostrados nas áreas do Vale do Rio Pilões (RP), Caminho do Mar (CM) e Vale do Rio Mogi (VM). Letras diferentes correspondem a médias estatisticamente diferentes $(\mathrm{p}<0,05)$. 
As maiores variações nos teores de fibras, entre os períodos de amostragem, foram observadas no Vale do Rio Mogi (Fig. 15A), porém, considerando os valores médios, somente no Caminho do Mar as concentrações foliares de fibras foram significativamente superiores no inverno (Fig. 15B). Pode-se observar também que as folhas coletadas em 1996, nos dois locais poluídos, continham menores teores de fibras do que as coletadas em 1997 para os mesmos pontos de amostragem (Fig. $15 \mathrm{C})$.

No caso de ligninas, não foram observadas diferenças claras entre os valores encontrados nos diversos períodos de amostragem. Pode ser mencionado que o conteúdo de ligninas foi significativamente maior em folhas retiradas no Caminho do Mar, no inverno de 1997 (Fig. 16A), o que resultou na elevação da média geral dos valores detectados para o inverno (Fig. 16B).

Van Soest (1963), desenvolvendo metodologia baseada no uso de soluções detergentes para quantificação de fibras e ligninas foliares, observou um intervalo de valores para fibras e ligninas obtido através da análise de várias espécies vegetais. Tal intervalo variava de 25 a $54 \%$ para fibras e de 2 a 12\% para ligninas. Para Swain (1979), os valores de ligninas podem variar desde zero, nas partes submersas de plantas aquáticas até valores maiores que $40 \%$ em extratos de madeira, sendo o polímero natural mais abundante depois da celulose. Os valores encontrados de fibras e ligninas para Tibouchina pulchra, mesmo sob influência da poluição atmosférica, encontram-se dentro dos intervalos observados pelos autores.

Alguns autores comentam a influência da concentração de nitrogênio nos teores de fibras e ligninas durante suas extrações e quantificações, havendo uma superestimativa da quantidade desses compostos. Assim, plantas com maiores concentrações de nitrogênio (protéico ou não) tendem a alterar para mais os teores de fibras e ligninas, devido a um mecanismo que ligaria esse elemento às ligninas durante o processo de extração (Schweizer \& Würsch, 1979; Makkar \& Singh, 1991; Hatfield et al., 1994). Tal interferência na metodologia, aparentemente não foi observada neste estudo, uma vez que os valores 


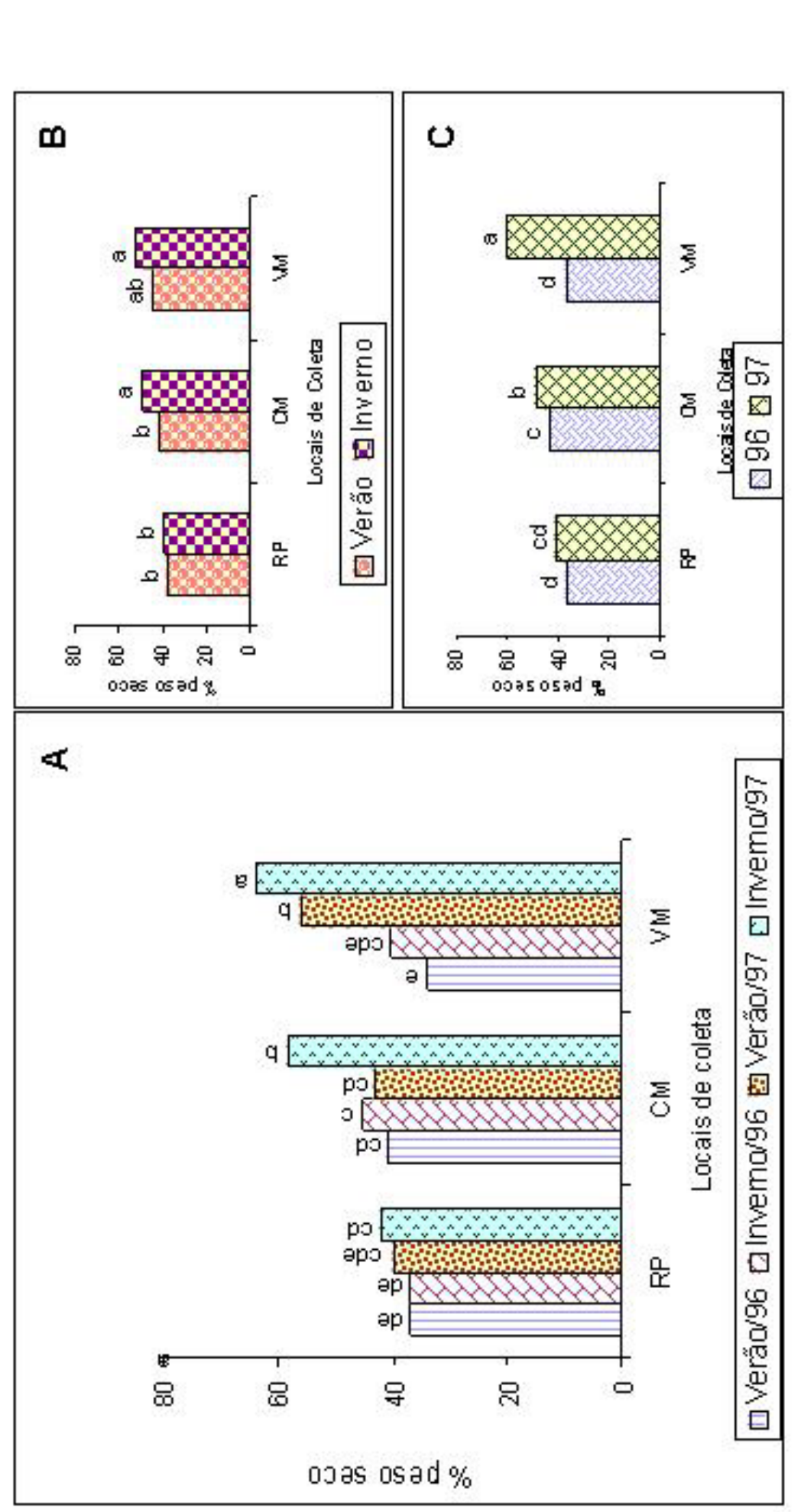

융

速 ॥

咕要

要思䓌

总蓉

要遂

总

융

范

空密

8 要

营要

西

兽穴

뉼

吕本

兽思

鄫宫

몽ㅁㅁㅇ

吉要是

记

惯

品

㟧要

运?

¿今

प

量实

닐 ॥

이음

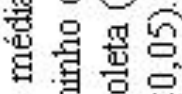

象总

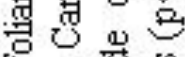

ख

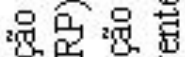

营岕密 总洎营

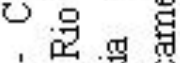
的吕曾总 的焉

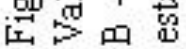




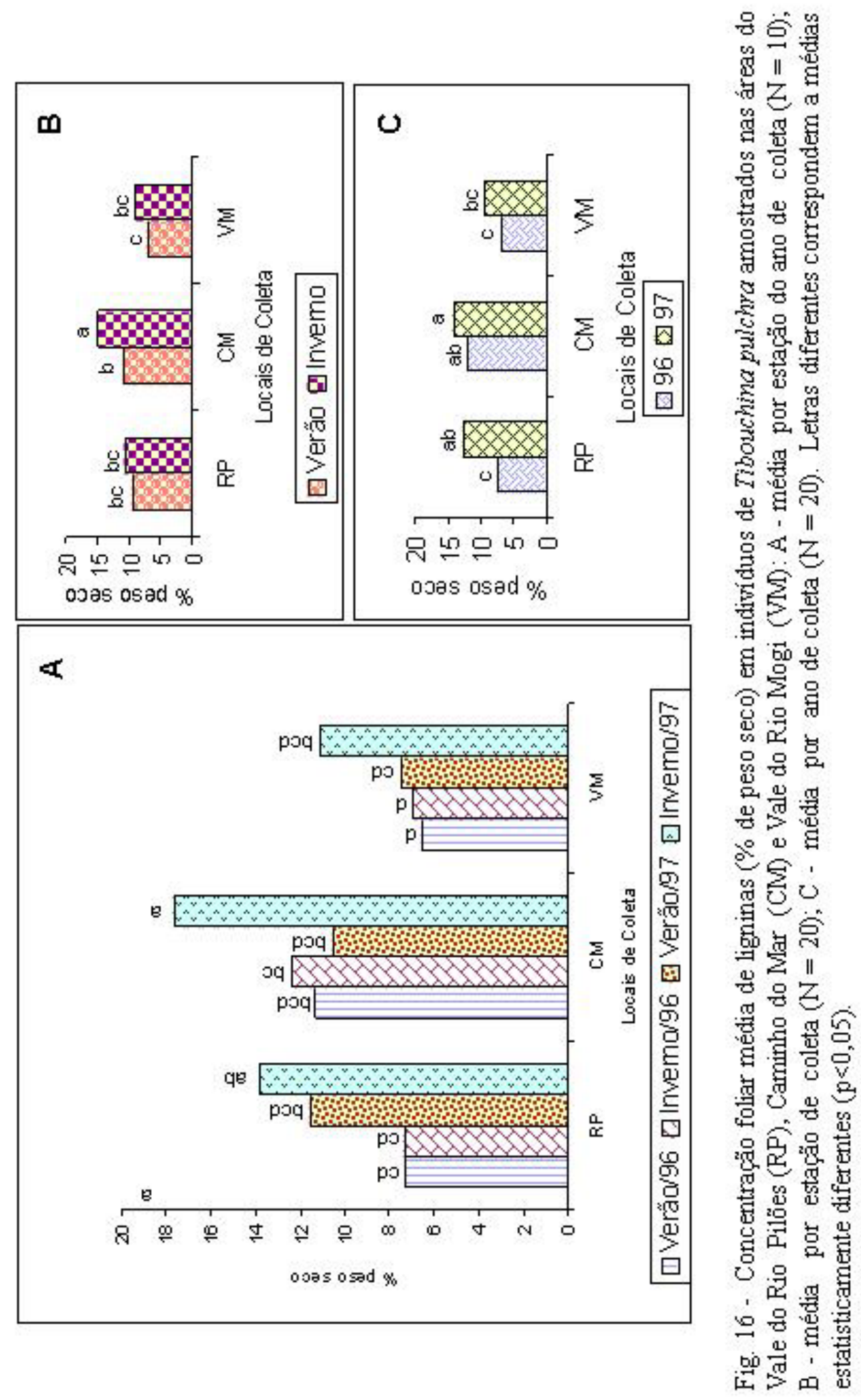


encontrados de fibras e ligninas para os indivíduos do Vale do Mogi, que possuem em média maiores concentrações de nitrogênio foliar, não foram os maiores.

A definição de fibras do ponto de vista dietético e ecológico não coincide com o conceito de fibras empregado em histologia e anatomia vegetal. As fibras quantificadas neste estudo são definidas por Trowell et al. (1976, apud Selvendran et al., 1989) como todos os polissacarídeos e ligninas que, na dieta alimentar, não são digeridos pelos processos digestivos, e são insolúveis em solventes orgânicos e detergentes, sendo estudadas em vários trabalhos relacionados à agricultura e zootecnia para o conhecimento e seleção de espécies com maior digestibilidade e qualidade nutricional.

Quimicamente as fibras são formadas por polímeros de carboidratos (celulose, hemicelulose), pectinas, ligninas, cutinas etc., que podem ser digeridos apenas se o herbívoro possuir enzimas especializadas. Esses componentes não digeríveis são geralmente divididos em solúveis e insolúveis. Hemiceluloses, celuloses e ligninas são classificadas como componentes insolúveis (Yoshida e Kuwano, 1989). São consideradas como um recurso de defesa anti-herbivórica, uma vez que tendem a aumentar o volume de material ingerido pelo herbívoro sem acrescentar nutrientes aproveitáveis, além de, juntamente com cristais, taninos e ligninas alterarem a digestibilidade do material vegetal por causarem redução no aproveitamento de proteínas (Selvendran et al., 1989).

Já as ligninas, um dos componentes das fibras e o principal constituinte das madeiras (22-34\%) (Neish, 1965), são polímeros aromáticos de alto peso molecular (maior que 5000), formados por processos de polimerização de basicamente três monômeros de fenilpropanóides: álcoois coniferílico, sinapílico e $p$-cumarílico (Swain, 1979; Dence \& Lin, 1992). Como possuem uma organização caótica, pois os monômeros são combinados de forma aleatória, sua química é imprevisível, dificultando o processo de quantificação, que pode ser influenciado principalmente pela associação desse polímero com, por exemplo, hemiceluloses, ou pela sua afinidade com proteínas 
(Selvendran et al, 1989). Além da sua importância em dar rigidez às paredes das células, principalmente para as plantas terrestres, que podem chegar a atingir grande crescimento em altura, auxilia no transporte de solutos uma vez que reduz a permeabilidade da parede celular do xilema e também é importante como defesa ao ataque de microorganismos (Higuchi, 1981).

Segundo Jones \& Coleman (1991), plantas expostas a poluição como a outros fatores de estresse tendem a apresentar deposição de compostos fenólicos ou lignificação das paredes celulares. Compostos fenólicos são quimicamente reativos, podendo induzir um estresse oxidativo, pois qualquer oxidação que sofram pode gerar radicais superóxido e peróxido, que são extremamente tóxicos para as células, inativando enzimas, causando oxidação de membranas e quebra de DNA (Appel, 1993; Summers \& Felton, 1994). Um dos processos que pode reduzir a probabilidade dos compostos fenólicos interferirem nas reações enzimáticas na célula é a polimerização, uma vez que o aumento no peso molecular leva a uma diminuição na capacidade de transporte do composto formado.

Harborne (1980) e Malhotra \& Khan (1984) discutem o envolvimento de enzimas no metabolismo fenólico, como a fenilalanina amonialiase (PAL), polifenoloxidase e peroxidase. Malhotra \& Khan (1984) citam como um dos efeitos do ozônio o aumento na atividade dessas enzimas, levando a um estímulo na oxidação de fenóis, gerando quinonas e acúmulo de produtos de polimerização. Domingos et al. (1993), Klumpp et al. (1997) e Domingos (1998) encontraram maior atividade da peroxidase nos indivíduos de Tibouchina pulchra, Cecropia glazioui e Psidium guajava expostos nas áreas do Caminho do Mar e Vale do Rio Mogi. Tibouchina pulchra apresentou em média 64 $\Delta \mathrm{E} / \mathrm{min} / \mathrm{g}$ peso fresco de atividade da peroxidase nas áreas do Caminho do Mar e Vale do Rio Mogi, enquanto que as plantas do Vale do Rio Pilões apresentaram em média $46 \Delta \mathrm{E} / \mathrm{min} / \mathrm{g}$ peso fresco de atividade dessa enzima (Klumpp et al., 1997). Esses resultados podem indicar um estresse oxidativo resultante de alteração no sistema enzimático de 
controle da síntese de fenóis, levando a um aumento na síntese de ligninas foliares dos indivíduos de Tibouchina pulchra dessas áreas.

Entretanto, ao contrário dos outros parâmetros avaliados, os valores de ligninas encontrados demonstram uma reação diferenciada entre os pontos poluídos do Caminho do Mar e Vale do Rio Mogi. As plantas do Caminho do Mar apresentaram um aumento nos teores de ligninas foliares, enquanto que as plantas do Vale do Rio Mogi apresentaram diminuição, quando comparados com os valores encontrados para a área de referência. Esse efeito pode ser atribuído ao tipo de poluição presente em cada região.

Também foi verificado em outros estudos alterações nos padrões de crescimento da planta. Domingos (1998) observou que mudas de Tibouchina pulchra expostas à poluição do Caminho do Mar apresentaram redução no incremento em altura quando comparadas com as plantas do Vale do Rio Pilões e do Rio Mogi. Pompéia (1997), considerando várias espécies vegetais ocorrentes na região, observou que há maior esclerofilia nos indivíduos das áreas poluídas, o que poderia contribuir indiretamente para uma maior tolerância ao estresse hídrico, uma vez que o efeito dos poluentes quase sempre resulta em sintomas semelhantes ao do estresse hídrico.

$\mathrm{Na}$ região do Caminho do Mar há a influência principalmente de poluentes orgânicos (hidrocarbonetos) e secundários (PAN, ozônio), e no Vale do Mogi há maior presença de compostos de enxofre e nitrogenados, fluoretos e material particulado, o que talvez possa levar a um efeito diferenciado na síntese de ligninas. Entre os poluentes, particularmente o ozônio pode favorecer a formação de ligninas, cuja biossíntese depende da formação de pontes cruzadas entre monômeros previamente oxidados e convertidos em radicais livres (Harborne, 1980; Dence \& Lin, 1992; Appel, 1993). Os maiores valores de ligninas encontrados nas plantas do Caminho do Mar pode ser devido a presença de ozônio em maior concentração nessa área, que apresentou média anual de 80,2 $\mu \mathrm{g} / \mathrm{m}^{3}$ entre os anos de 1994 e 1995, enquanto as áreas do Vale do Rio Mogi e do Rio Pilões apresentaram médias de concentração 
menores para esse poluente, ambos com $29 \mu \mathrm{g} / \mathrm{m}^{3}$ de média entre os anos de 1991 a 1995.

\section{5. Área Foliar}

As análises de área foliar revelaram a tendência dos indivíduos do Caminho do Mar apresentarem, em média, menor área foliar total (1673 $\mathrm{mm}^{2}$ ) quando comparados com os indivíduos do Vale do Rio Pilões $\left(1980 \mathrm{~mm}^{2}\right)$ e do Vale do Rio Mogi $\left(1876 \mathrm{~mm}^{2}\right)$ embora não haja diferença significativa entre esses resultados, assim como os indivíduos do Caminho do Mar e do Vale do Rio Pilões apresentaram menor porcentagem de área foliar perdida por herbivoria do que os indivíduos do Vale do Rio Mogi (Tab. 7). A porcentagem de herbivoria foliar foi significativamente menor $(\mathrm{p}<0,05)$ nos indivíduos das áreas do Vale do Rio Pilões e do Caminho do Mar em relação a encontrada nos indivíduos da área do Vale do Mogi (VM>CM=RP) (Fig. 17). Entretanto, os valores percentuais de herbivoria foliar encontrados podem ter sido subestimados, uma vez que foi estimada apenas a área foliar perdida, não sendo consideradas as folhas que foram completamente retiradas, minas e galhas.

$\mathrm{Na}$ figura 18 estão representados os valores médios de porcentagem de área foliar perdida por herbivoria por estação do ano em cada ano de coleta, os valores médios por estação do ano de coleta e os valores médios por ano de coleta. Em todos os locais, diferenças entre a porcentagem de área perdida por herbivoria, tanto no inverno como no verão ou entre os dois anos de amostragem, não foram evidenciadas.

Cersósimo (1993), estudando a herbivoria foliar em folhas jovens e maduras de espécies de Mata de Planalto encontrou uma taxa de dano entre $60-95 \%$ dos indivíduos amostrados mensalmente, sendo o menor valor encontrado nos meses de verão, atribuindo esse resultado ao alto índice pluviométrico que ocorre nesses meses, levando, principalmente, a uma redução na densidade de insetos. Entretanto, se considerarmos os resultados de área foliar perdida por herbivoria apenas por estação do ano de coleta, ou seja, verão e inverno, sem considerar o local de coleta, 
Tab. 7 - Área foliar total e perdida por herbivoria em indivíduos de Tibouchina pulchra $(\mathrm{N}=5)$ amostrados nas áreas do Vale do Rio Pilões (RP), Caminho do Mar (CM) e Vale do Rio Mogi (VM).

\begin{tabular}{|c|c|c|c|c|c|c|c|c|c|c|c|c|}
\hline & \multicolumn{6}{|c|}{ Área foliar total $\left(\mathrm{mm}^{2}\right)$} & \multicolumn{6}{|c|}{ \% de Área Perdida } \\
\hline & \multicolumn{2}{|c|}{$\mathrm{RP}$} & \multicolumn{2}{|c|}{$\mathrm{CM}$} & \multicolumn{2}{|c|}{ VM } & \multicolumn{2}{|c|}{$\mathrm{RP}$} & \multicolumn{2}{|c|}{$\mathrm{CM}$} & \multicolumn{2}{|c|}{$\mathrm{VM}$} \\
\hline & Média & Desvio & Média & Desvio & Média & Desvio & Média & Desvio & Média & Desvio & Média & Desvio \\
\hline Jan./96 & 2097,6 & 339,6 & 1708,8 & 608,8 & 1706,1 & 108,8 & 0,28 & 0,20 & 0,46 & 0,20 & 3,29 & 1,57 \\
\hline Fev./96 & 1960,8 & 453,0 & 1701,3 & 362,4 & 1482,7 & 238,0 & 1,30 & 0,30 & 1,22 & 0,70 & 3,41 & 3,07 \\
\hline Jun./96 & 1868,9 & 231,6 & 1274,2 & 81,5 & 1681,0 & 478,2 & 1,04 & 0,70 & 1,27 & 1,30 & 1,92 & 1,16 \\
\hline Jul./96 & 2035,8 & 383,8 & 1421,9 & 218,1 & 2070,5 & 276,6 & 1,54 & 0,60 & 1,29 & 0,60 & 4,33 & 2,56 \\
\hline Jan./97 & 2262,5 & 295,2 & 2493,9 & 819,4 & 2908,2 & 457,3 & 2,09 & 1,20 & 3,95 & 2,60 & 5,08 & 1,18 \\
\hline Fev./97 & 2127,7 & 214,5 & 1732,0 & 350,1 & 2098,3 & 395,6 & 1,28 & 0,50 & 2,89 & 2,80 & 3,07 & 1,25 \\
\hline Jun./97 & 1709,0 & 419,7 & 1539,9 & 236,6 & 1482,1 & 292,9 & 1,64 & 1,00 & 1,15 & 1,30 & 5,08 & 3,54 \\
\hline Jul./97 & 1778,9 & 601,9 & 1503,0 & 302,9 & 1579,7 & 284,3 & 0,00 & 0,00 & 0,45 & 1,00 & 1,48 & 1,80 \\
\hline
\end{tabular}


observa-se uma tendência de maior herbivoria durante o verão, embora não seja um resultado estatisticamente significante (Fig. 19).

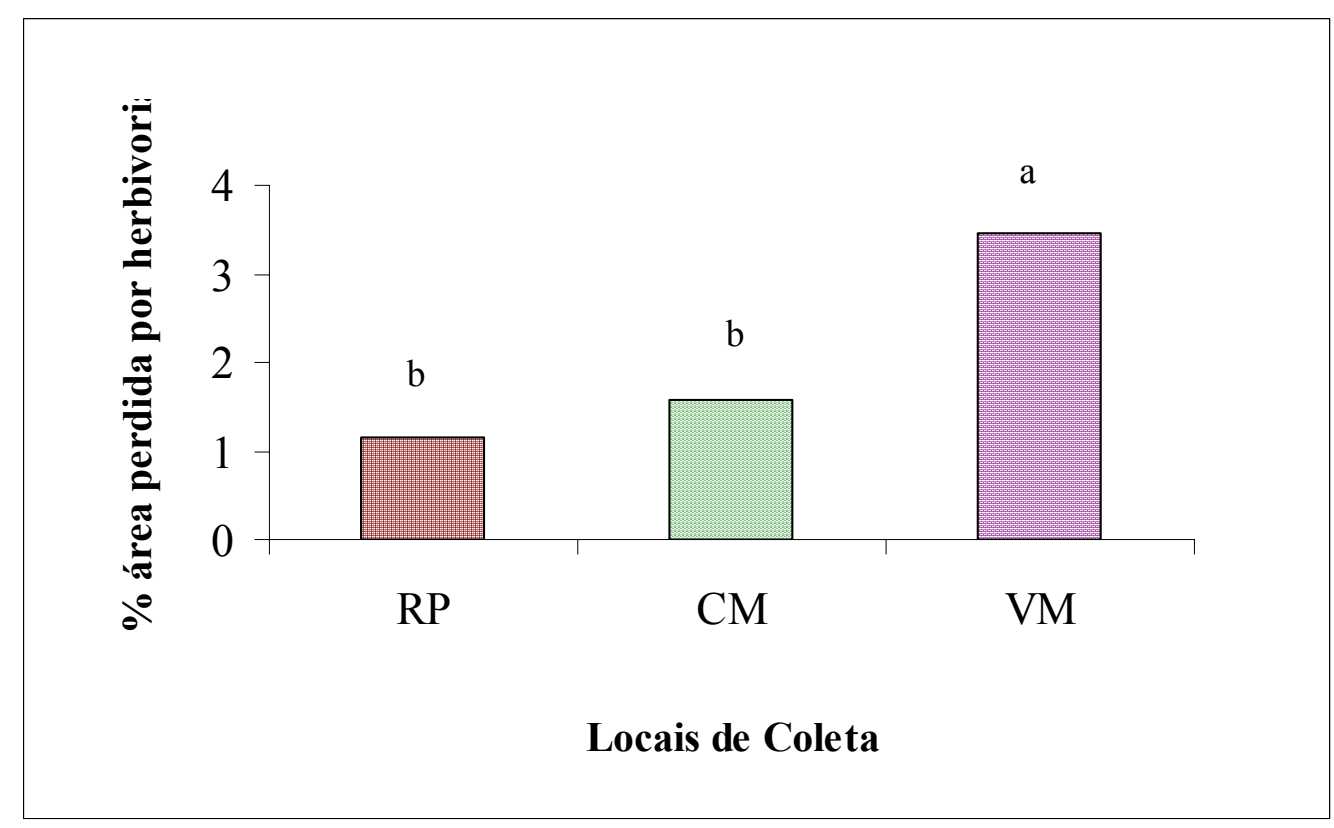

Fig. 17 - Porcentagem média de área foliar perdida por herbivoria em indivíduos de Tibouchina pulchra $(\mathrm{N}=40)$ amostrados nas áreas do Vale do Rio Pilões (RP), Caminho do Mar (CM) e Vale do Rio Mogi $(\mathrm{VM})$. Letras diferentes correspondem a médias estatisticamente diferentes $(\mathrm{p}<0,05)$.

Mazzoni-Viveiros (1996), estudando indivíduos adultos de Tibouchina pulchra nas regiões do Vale do Rio Mogi, Vale do Rio Pilões e Paranapiacaba (no alto da Serra do Mar), verificou uma tendência à redução da lâmina foliar nos indivíduos expostos à poluição atmosférica. Nesse trabalho, pode-se verificar alterações na organização cuticular e uma significativa redução no comprimento da cadeia carbônica de ceras epicutilulares. A composição e organização da cutícula são fatores que atuam na resistência da folha ao ataque de insetos ou patógenos (Martin \& Juniper, 1970 apud Mazzoni-Viveiros, 1996). Dessa forma, os indivíduos das áreas poluídas estariam mais suscetíveis à herbivoria e, portanto, apresentariam maior porcentagem de área foliar com danos do que os indivíduos de áreas não poluídas. Entretanto, Mazzoni-Viveiros (1996) observou, apenas através de uma avaliação visual não quantitativa, maior taxa de herbivoria foliar na 


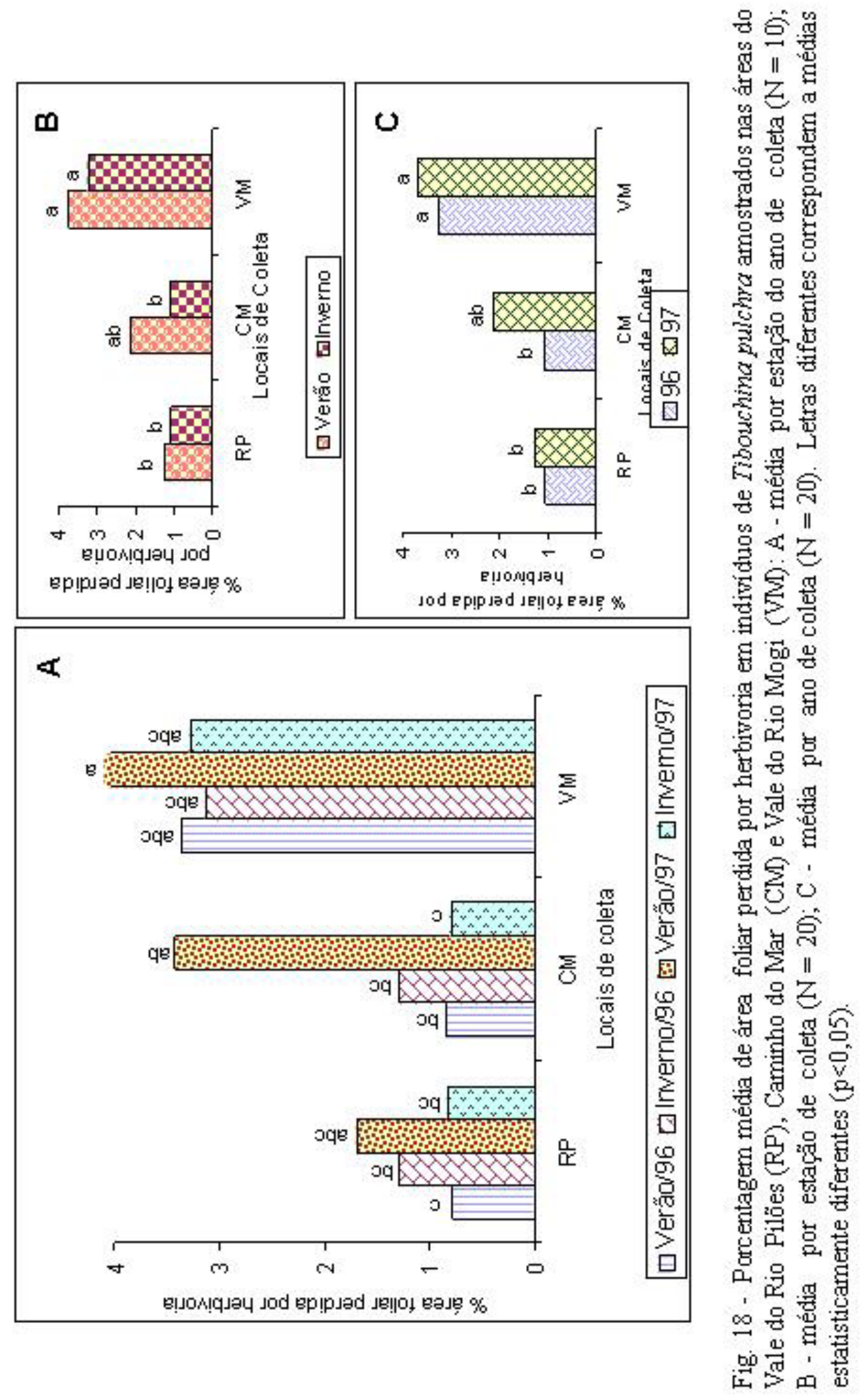


região de Paranapiacaba e Rio Pilões, e pequena taxa de herbivoria na área do Vale do Mogi, atribuindo esse resultado a uma modificação do comportamento do inseto devido ao índice de poluição.

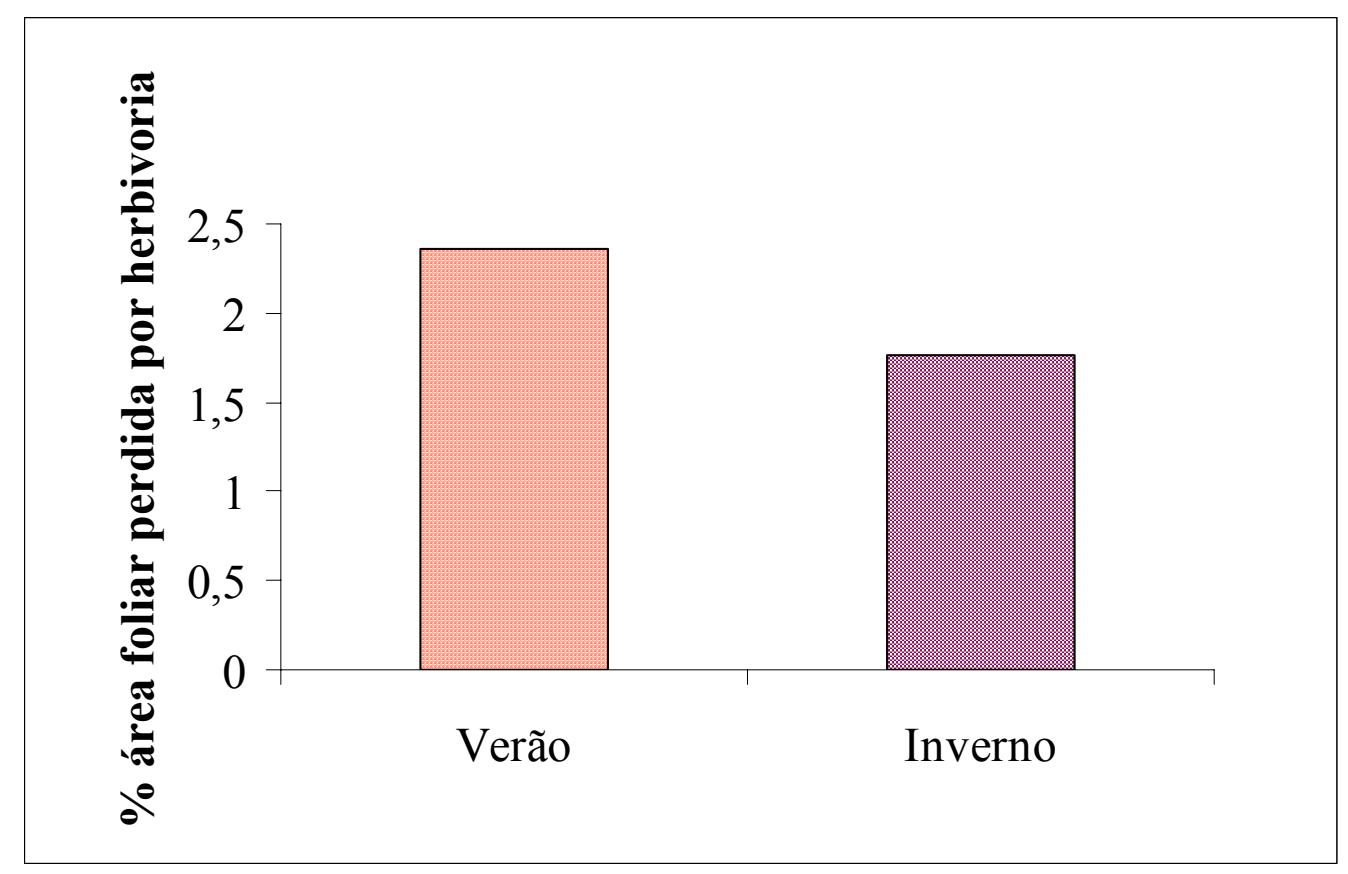

Fig. 19 - Porcentagem média de área foliar perdida por herbivoria em indivíduos de Tibouchina pulchra $(\mathrm{N}=60)$ amostrados nos meses de verão e de inverno.

Os herbívoros podem retirar anualmente cerca de 7,5\% da área foliar em floresta temperadas e $11 \%$ em florestas tropicais. Os principais fatores que afetam o grau de herbivoria foliar são a idade da folha (folhas jovens são preferidas), palatabilidade do material vegetal (defesas químicas, estruturais e qualidade nutricional), tamanho da planta e variações nos padrões climáticos (Aide \& Zimmerman, 1990). Menor pressão herbivórica nas regiões temperadas é esperada devido à variação sazonal bem definida dos períodos de frio e seca, que acabam influenciando tanto a produção de folhas como as populações de insetos. O contrário é esperado para as florestas tropicais, onde não há uma delimitação clara das estações do ano e o controle climático da abundância de herbívoros não é tão eficiente (Coley \& Aide, 1991).

Segundo La Cruz \& Dirzo (1987, apud Cersósimo, 1993) é possível identificar, pelo tipo de dano nas folhas, qual o herbívoro 
responsável. Em plântulas de florestas tropicais os autores encontraram: $26,8 \%$ de mordidas irregulares na extremidade da folha, causada por insetos das ordens Lepidoptera e Orthoptera; 19,3\% de buracos com diâmetro menor que $2 \mathrm{~mm}$, causados por Lepidoptera e Hymenoptera; $17,8 \%$ de buracos com diâmetro maior que $2 \mathrm{~mm}$, causados por Coleoptera; $5,9 \%$ de mordidas regulares na extremidade da folha, causados por Hymenoptera, especialmente formigas; 4,7\% de esqueletização, causada por Lepidoptera e Coleoptera; $1 \%$ de minas, causadas por Lepidoptera e Diptera; $8,9 \%$ de manchas e necroses por patógenos e 15,9\% de danos mecânicos.

Embora não se tenham quantificado os percentuais de tipos de dano foliar neste trabalho, pode-se observar na figura 20 que a maior parte das folhas de Tibouchina pulchra consumidas por herbivoria, em qualquer um dos três locais de coleta, é na forma de buracos maiores que $2 \mathrm{~mm}$ de diâmetro e mordidas irregulares na extremidade da folha, mais provavelmente relacionadas à ação de insetos das ordens Lepidoptera, Orthoptera ou Coleoptera. Resultado semelhante foi encontrado por Cersósimo (1993) para espécies da Mata de Planalto, onde se observou maior consumo foliar por insetos das ordens Lepidoptera e Coleoptera.

$\mathrm{Na}$ tabela 8 estão listadas as porcentagens médias de galhas em cada coleta para cada área amostrada. Foi observada a presença de galhas na superfície adaxial das folhas (Fig. 21), em maior porcentagem média nas plantas amostradas na área do Vale do Mogi, seguidas pelas do Vale do Rio Pilões e pelas do Caminho do Mar (VM $>$ RP $>C M$ ) (Fig. 22).

Tanto nos meses de verão como nos de inverno, a quantidade de galhas foi maior na área do Vale do Mogi quando comparados com os resultados obtidos para o Rio Pilões, mas não foi observado o mesmo resultado para a área do Caminho do Mar. Mesmo não havendo uma diferença estatisticamente comprovada para a porcentagem de galhas encontradas durante os meses de verão e inverno parece haver uma tendência a um efeito da estação do ano na intensidade dos danos 


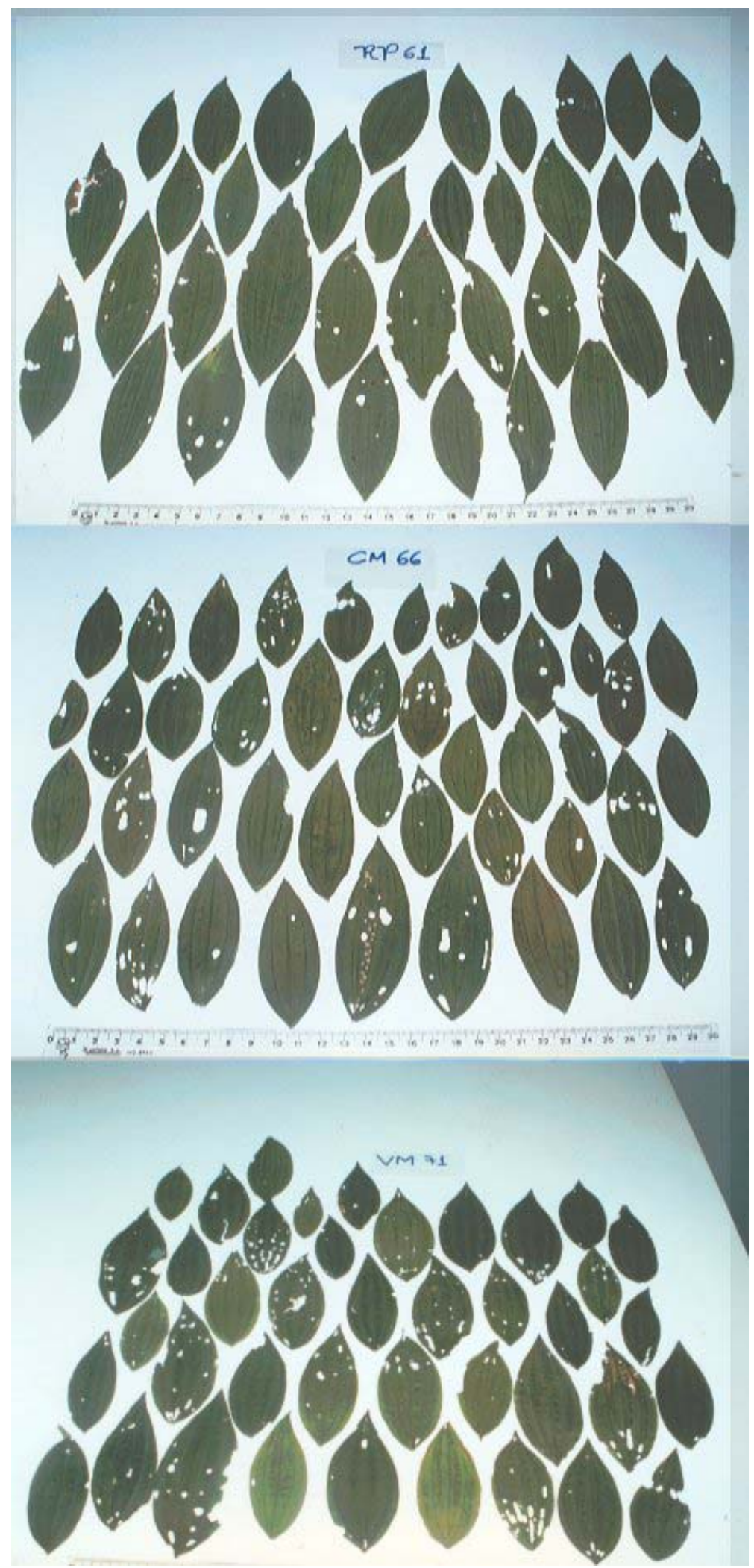

Fig. 20 - Folhas de Tibouchina pulchra amostradas nas áreas do Vale do Rio Pilões (RP), Caminho do Mar (CM) e Vale do Rio Mogi (VM) utilizadas para a análise de área foliar perdida por herbivoria. 
causados por um ou outro tipo de herbívoro (cortadores ou galhadores), principalmente na região do Vale do Mogi, com maior ação de herbivoria por consumo de área foliar no verão, enquanto no inverno há maior desenvolvimento de galhas (Fig. 23).

Tab. 8 - Porcentagem média de galhas foliares em indivíduos de Tibouchina pulchra $(\mathrm{N}=5)$ amostrados nas áreas do Vale do Rio Pilões (RP), Caminho do Mar (CM) e Vale do Mogi (VM). (* não quantificado)

\begin{tabular}{|c|c|c|c|c|c|c|}
\hline & \multicolumn{2}{|l|}{$\mathrm{RP}$} & \multicolumn{2}{|c|}{$\mathrm{CM}$} & \multicolumn{2}{|c|}{ VM } \\
\hline & Média & Desvio & Média & Desvio & Média & Desvio \\
\hline Jan./96 & $*$ & $*$ & $*$ & $*$ & $*$ & $*$ \\
\hline Fev./96 & $*$ & $*$ & $*$ & $*$ & $*$ & $*$ \\
\hline Jun./96 & 3,00 & 3,26 & 1,00 & 1,37 & 15,00 & 3,54 \\
\hline Jul./96 & 6,00 & 4,18 & 1,50 & 2,24 & 8,50 & 3,79 \\
\hline Jan./97 & 3,50 & 2,85 & 1,50 & 2,24 & 7,00 & 4,11 \\
\hline Fev./97 & 8,50 & 8,02 & 1,50 & 2,24 & 5,00 & 3,54 \\
\hline Jun./97 & 2,50 & 3,06 & 1,50 & 2,24 & 8,50 & 4,87 \\
\hline Jul./97 & 2,00 & 2,09 & 0,50 & 1,12 & 6,50 & 4,54 \\
\hline
\end{tabular}

$\mathrm{Na}$ figura 24 estão representados os valores médios de porcentagem de galhas foliares por estação do ano e ano de coleta, os valores médios por estação do ano de coleta e os valores médios por ano de coleta de galhas. Diferenças entre os valores, obtidos nos diferentes períodos de amostragem, não foram comprovadas. Pode-se apenas dizer que o número de galhas em folhas provenientes do Vale do Rio Mogi, no ano de 1996, foi maior do que o observado no ano seguinte 


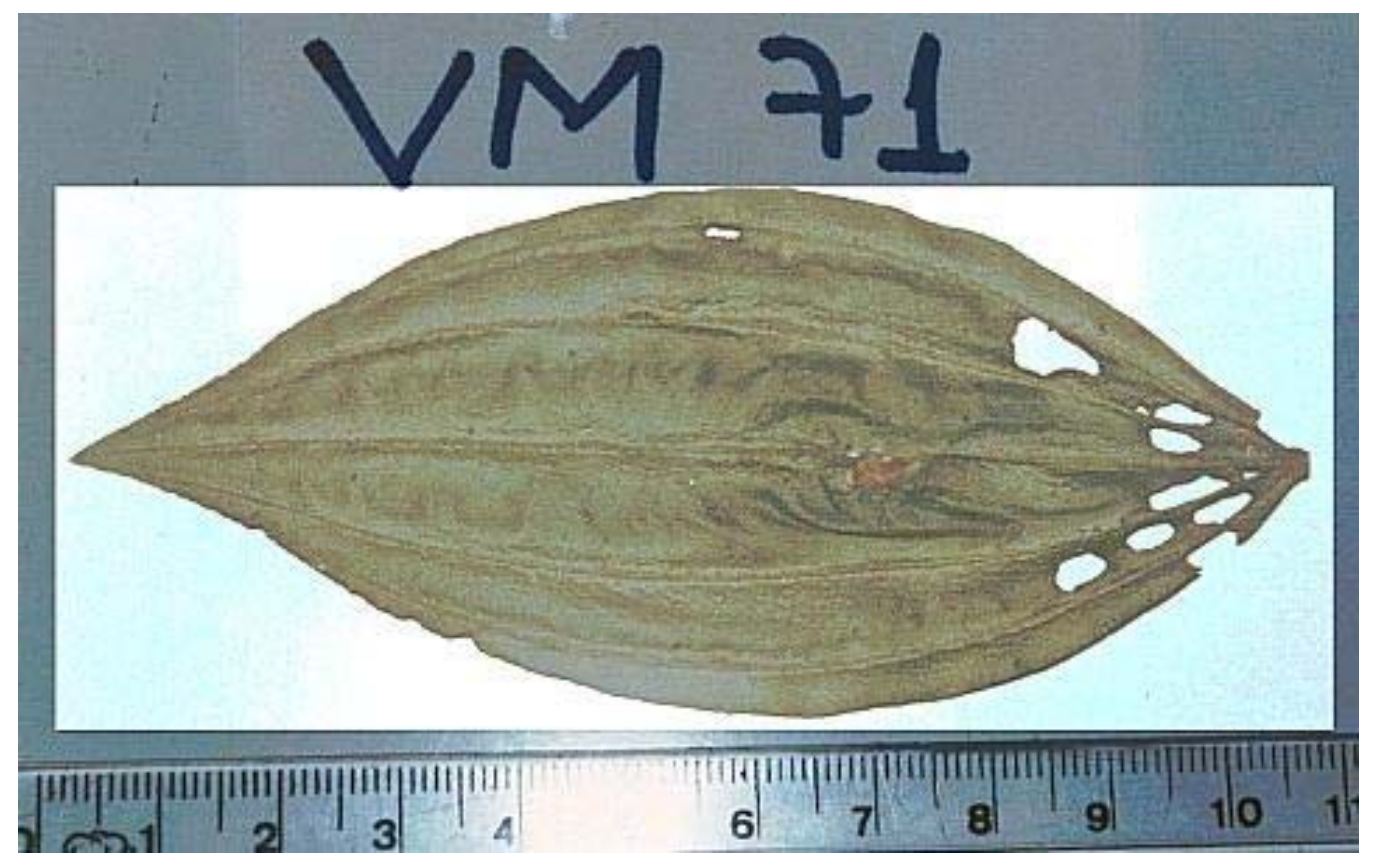

Fig. 21 - Folha de Tibouchina pulchra com danos causados por herbivoria. Observar galha ao redor da nervura central.

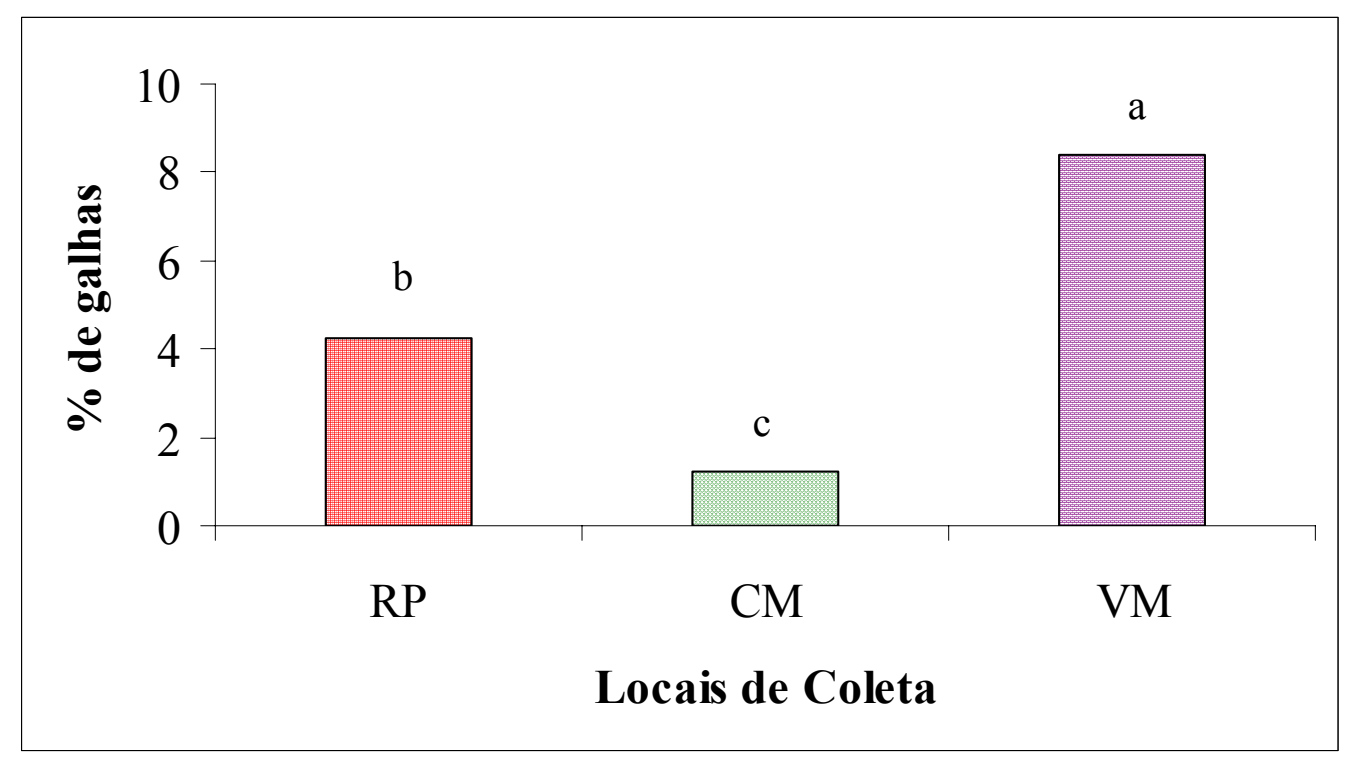

Fig. 22 - Porcentagem média de galhas em indivíduos de Tibouchina pulchra $(\mathrm{N}=40)$ amostrados nas áreas do Vale do Rio Pilões $(\mathrm{RP})$, Caminho do Mar (CM) e Vale do Rio Mogi. Letras diferentes correspondem a médias estatisticamente diferentes $(\mathrm{p}<0,05)$. 


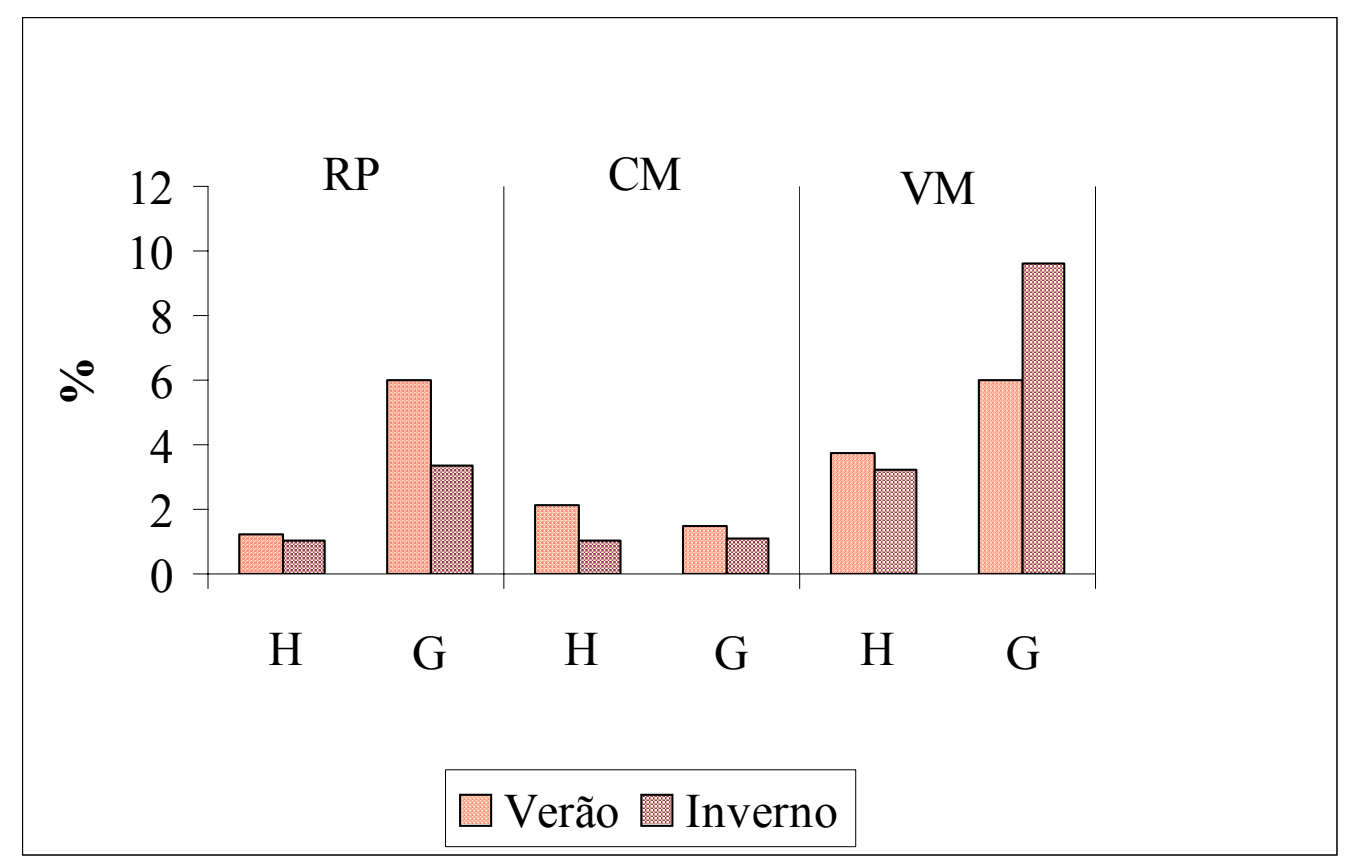

Fig. 23 - Porcentagem média de área foliar perdida por herbivoria $(\mathrm{H})$ e de galhas $(\mathrm{G})$ em indivíduos de Tibouchina pulchra $(\mathrm{N}=10)$ amostrados nos meses de verão e inverno, nas áreas do Vale do Rio Pilões (RP), Caminho do Mar (CM) e Vale do Rio Mogi (VM).

A menor quantidade de galhas foliares na área do Caminho do Mar, talvez possa ser explicada pela maior quantidade de fibras e ligninas foliares encontradas nessa área, minimizando o efeito de herbívoros e dificultando a formação de galhas. Entretanto, sabe-se que as plantas do Cerrado são bastante ricas em defesas químicas do tipo fenólica, fibras e ligninas e mesmo assim são atacadas por insetos galhadores, havendo uma grande diversidade de tipos de galhas nesse ambiente.

Além das concentrações de defesas químicas e da idade da folha, segundo Basset (1991), há uma estratificação na quantidade de galhas em relação à iluminação, ou seja, folhas mais expostas à luz tendem a ser menos predadas. Dessa forma, o fator luz, a idade da folha e as concentrações de defesas químicas são igualmente importantes para a distribuição espacial de galhas.

Segundo Alstad et al. (1982), Huttunen (1984) e Hughes (1988), a poluição atmosférica vem sendo associada a efeitos diretos e indiretos sobre as populações de insetos. No primeiro caso tem-se a ação tóxica, estimulando o metabolismo ou alterando o comportamento do inseto, 


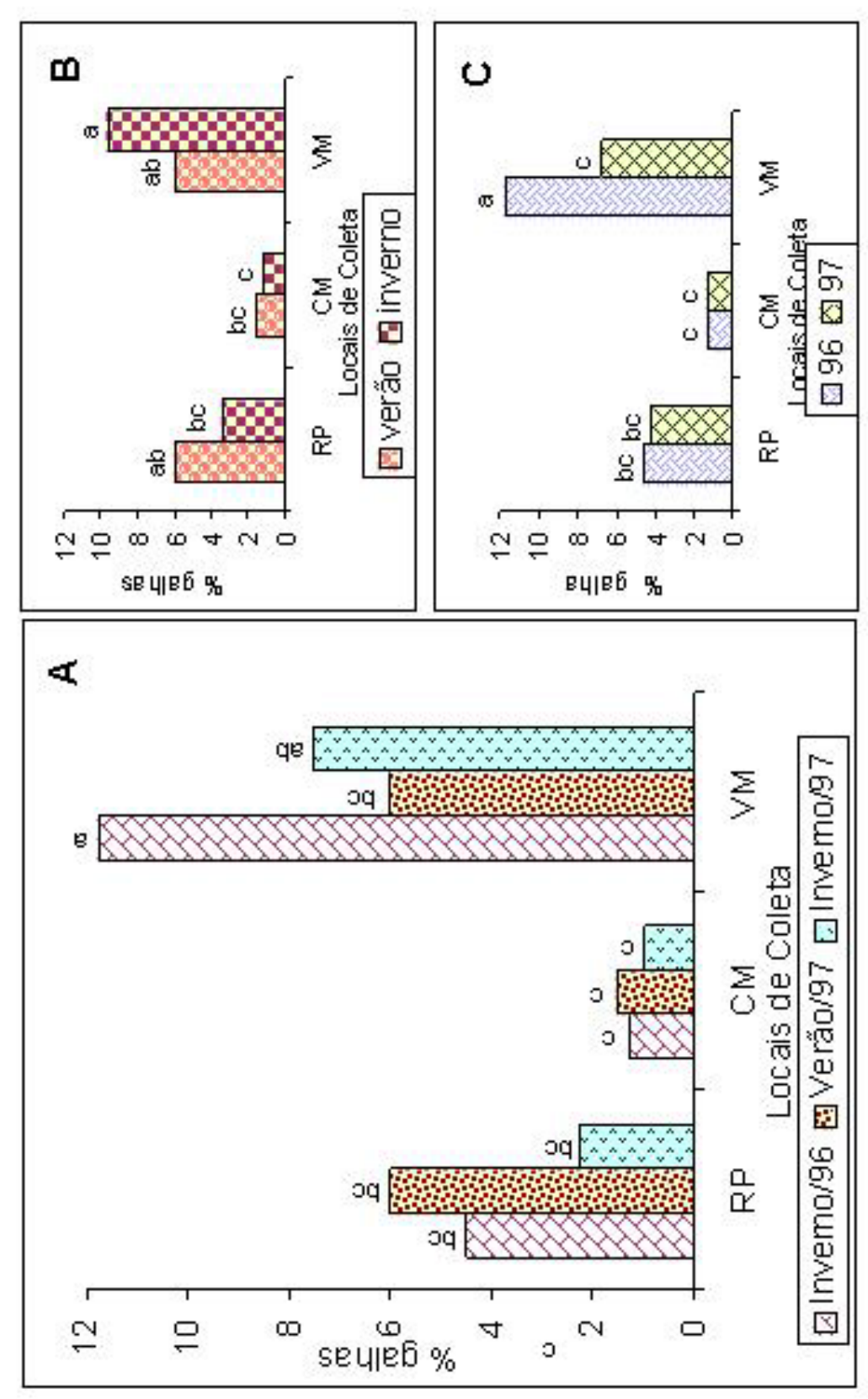

误 . 总兽 总学 象賈 융 嵒的蕒 $>\ldots$ 융 이룔 过 娄范 然 总 罗명 橓䓌 용용 둥 尊 语 涩 可 . 밈 별 뭠 क \& 导 密要 四 实 믐 虽

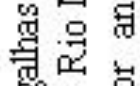
害骂营 뮴

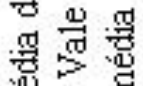
总要 急实 垩牙

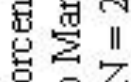

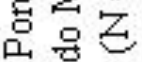
我覓要合 
enquanto que no segundo caso há interações secundárias que podem resultar em um aumento ou diminuição na abundância de insetos, como mudanças no equilíbrio entre seus predadores e parasitas devidas, por exemplo, ao aumento na quantidade de material particulado, levando a uma maior dificuldade para a predação. Podem ser citadas também mudanças estruturais, fisiológicas ou metabólicas das plantas, como alterações quantitativas e qualitativas de alguns compostos secundários, influenciando a palatabilidade e/ou qualidade nutricional; mudanças microclimáticas; e alterações na abundância ou distribuição das plantas (Treshow, 1975; Huttunen, 1984; Hughes, 1988).

Poucos são os estudos sobre a toxicidade de determinados poluentes sobre os insetos. Em geral, estes são relativamente insensíveis à maioria dos poluentes gasosos e particulados presentes no ambiente, mas são afetados quando há ingestão de formas desses poluentes solúveis em água. A estimulação do metabolismo do inseto por formas tóxicas de poluentes é o efeito mais descrito, como no caso da larva de Oncopeltus fasciatus quando exposta a doses de $\mathrm{SO}_{2}, \mathrm{CO}$ e $\mathrm{NO}$ (Feir \& Hale, 1983 apud Hughes 1988); ou do estímulo da oviposição de Musca domestica, Stomoxys calcitrans e Drosophila melanogaster quando expostos a concentrações de fluoretos, resultando em um aumento da população dessas espécies (Hughes, 1988). Alterações no comportamento, como atração ou repelência, são casos menos estudados quando relacionados com poluição atmosférica.

Entre os efeitos na vegetação que afetam indiretamente os insetos estariam as mudanças na qualidade nutricional, como níveis de metabólitos primários e secundários, balanço hídrico, atividade metabólica; mudanças na quantidade de defesas da planta, sejam elas constitutivas, morfológicas ou químicas, sejam induzidas, como no caso de fitoalexinas; translocação indireta de compostos; alterações na expressão gênica (Hughes, 1988).

Para Louda \& Collinge (1992), situações de estresse alteram a fisiologia vegetal induzindo mudanças químicas que levam a um aumento na intensidade de herbivoria sofrida pela planta. De acordo com Harper (1990), a ação de herbívoros só causa a morte da planta quando o 
ataque ocorre no estágio de semente ou plântula ou quando a herbivoria é contínua, provocando assim um enfraquecimento da planta através da perda contínua de nutrientes e áreas fotossintetizantes, tornando a planta mais sensível a outros fatores de estresse. Para Sterck e colaboradores (1992), os herbívoros afetam as comunidades vegetais sob várias formas, alterando a taxa de crescimento, sobrevivência, alocação de recursos, arquitetura dos indivíduos e reprodução, entre outros parâmetros.

O ataque de insetos pode tornar a planta mais suscetível a ação da poluição atmosférica e em alguns casos pode reduzir a sensibilidade a alguns poluentes (Norris, 1988). As duas áreas poluídas amostradas neste estudo diferem no tipo e na concentração de poluentes e embora com uma mesma tendência de alterações fitoquímicas, apresentam uma resposta diferenciada para a porcentagem de área foliar forrageada. Os indivíduos de Tibouchina pulchra do Caminho do Mar têm maior quantidade de lignina foliar, podendo ser esta uma das razões para a menor porcentagem de herbivoria encontrada nessa área, em comparação com os indivíduos do Vale do Rio Mogi. Para Norris (1988), a lignificação das paredes celulares vem sendo associada à redução no dano celular causado pela poluição. Por sua vez, os insetos, através da herbivoria, podem estimular a biossíntese de fenilpropanóides em algumas espécies vegetais, o que pode reduzir a suscetibilidade à ação da poluição.

O tipo de poluente presente nas áreas amostradas, através de alterações fitoquímicas que modificam a palatabilidade e digestibilidade do material, pode estar influenciando direta ou indiretamente as populações de insetos, observando-se como conseqüência mudanças na porcentagem de herbivoria foliar. Esta, por sua vez, pode alterar a suscetibilidade da planta à ação da poluição. 


\section{EFEITOS DAS ALTERAÇÕES METABÓLICAS NA HERBIVORIA}

Vários trabalhos vêm demonstrando a importância da presença de compostos secundários para as interações das plantas com o meio ambiente, tanto como proteção contra o ataque por microorganismos e/ou animais, como para o aumento da habilidade na competição com outras plantas (Bell, 1980). Whittaker \& Feeny (1971) citam exemplos de substâncias aleloquímicas que agem alterando o crescimento, comportamento e biologia de organismos de outras espécies. Harborne (1987) traz uma revisão sobre vários tipos de interações de plantas com afídeos, formigas, besouros, lepidópteros, entre outros grupos de insetos, e quais compostos químicos estariam envolvidos nessas relações, tanto atraindo, no caso de polinizadores, como repelindo, no caso de predadores.

Em meados da década de cinqüenta, começaram a surgir trabalhos na área da ecologia química, com propostas de que a pressão herbivórica teria levado à seleção de caracteres vegetais com a capacidade de minimizá-la, surgindo assim as primeiras discussões sobre co-evolução animal-planta (Ehrlich \& Raven, 1964). O tipo e quantidade de defesas influenciam a dinâmica e distribuição das plantas e dos herbívoros que, por sua vez, influenciam na evolução das defesas. A variação entre as espécies ou comunidades nos níveis de defesas pode indicar o quanto elas diferem nas interações animal-planta (Coley \& Aide, 1991).

Uma das primeiras teorias para explicar os mecanismos de defesa da planta contra a ação de herbívoros surgiu em 1976, com trabalhos de Feeny e Rhoades $\&$ Cates, nos quais os autores consideravam que folhas jovens e plantas de estágios iniciais da sucessão são menos aparentes para os herbívoros e, portanto, menor seria o investimento em defesas químicas, acumulando-se preferencialmente defesas qualitativas, por exemplo alcalóides. Já as folhas maduras e plantas de estágios finais da sucessão seriam mais aparentes e mais defesas quantitativas seriam produzidas, ou seja, haveria maior acúmulo de macromoléculas como taninos, ligninas e fibras. Em 1985, Coley e colaboradores, propuseram a 
'teoria da alocação de recursos', considerando que a quantidade e o tipo de defesa anti-herbivórica dependem da taxa intrínseca de crescimento da espécie e da disponibilidade de nutrientes no ambiente (Coley, 1983; Coley et al., 1985).

Atualmente são discutidas duas hipóteses para explicar a suscetibilidade das plantas ao ataque de herbívoros. A hipótese do estresse propõe que, quando fisiologicamente estressadas, as plantas se tornam mais suscetíveis à ação de herbívoros, uma vez que têm a síntese de proteínas e defesas químicas reduzidas e aumento de aminoácidos livres nos tecidos, tornando-se mais palatáveis. Ao contrário, a hipótese do vigor propõe que partes de plantas ou indivíduos numa população que possuam crescimento mais vigoroso, com maior quantidade de água e nutrientes, como por exemplo plântulas e folhas jovens, são preferidos pelos herbívoros (Karban, 1990; Price, 1991; Louda \& Collinge, 1992).

Como citado anteriormente, os herbívoros afetam a comunidade vegetal de várias formas, tanto retirando biomassa, como afetando o número, o tipo ou a abundância relativa da espécies vegetais. Por outro lado, as plantas apresentam várias estratégias para minimizar a ação de herbívoros. Dentre elas, citam-se estruturas morfológicas que dificultam o ataque do herbívoro, como espinhos e tricomas; mutualismo com outras espécies, por exemplo mirmecofilia; diversidade de formas estruturais, que confundem visualmente os herbívoros; redução no valor nutricional; e produção de compostos tóxicos ou pouco digeríveis pelo herbívoro (Hanover, 1975; McNaughton, 1983; Aide \& Zimmerman, 1990; Huntly, 1991). O consumo de plantas inteiras ou de suas partes vem sendo apontado como importante agente regulador da dinâmica de comunidades vegetais, bem como da manutenção da diversidade específica e heterogeneidade espacial, sendo considerada como uma das interações animal-planta mais importantes (Prins \& Nell, 1990; Coley \& Aide, 1991).

A poluição atmosférica afeta as interações entre plantas e herbívoros, patógenos, parasitas e outros, alterando tanto as populações desses organismos como também o metabolismo vegetal, tornando a planta mais suscetível ou tolerante a mudanças no ambiente. Nos 
trabalhos de Heagle (1973), Treshow (1975), Huttunen (1984), Flückiger et al. (1987) e Hughes (1988) podem ser encontrados vários exemplos de efeitos de poluentes atmosféricos nas interações plantasanimais como conseqüência de mudanças metabólicas nas comunidades de plantas ou na forma de efeitos diretos nas populações de insetos ou patógenos.

As análises de correlações dos parâmetros estudados neste trabalho com a quantidade de herbivoria, quando não são separados os resultados por local de coleta, indicam que há uma correlação positiva e significante entre a porcentagem de herbivoria foliar nos indivíduos de Tibouchina pulchra e o parâmetro nitrogênio, ou seja, quanto maior o teor de nitrogênio das folhas, maior a porcentagem de área perdida por elas. O contrário foi encontrado para os teores de ligninas e taninos, observando-se uma correlação negativa entre a porcentagem de herbivoria foliar e os conteúdos foliares desses compostos, ou seja, quanto menores as concentrações de ligninas e taninos nas folhas, maior a porcentagem de área foliar perdida por herbivoria (Tab. 9).

Com relação aos outros parâmetros, pode-se observar que a quantidade de galhas é dependente dos fatores taninos, compostos fenólicos, e ligninas, havendo uma correlação positiva entre galhas, taninos e fenóis totais e uma correlação negativa com ligninas. Há uma influência da quantidade de nitrogênio nas concentrações de todos os outros compostos, podendo ser correlacionado negativamente com fenóis e taninos, e positivamente com fibras.

O valor nutricional da folha é um importante fator na seleção pelo herbívoro e, desta forma, geralmente folhas com maiores quantidades de nitrogênio são mais predadas. Segundo Azevedo et al. (1994) altas concentrações de nitrogênio podem aumentar a suscetibilidade da planta ao ataque por pragas e doenças. Fox \& Macauley (1977) verificaram que folhas de Eucalyptus sp., mesmo possuindo altas concentrações de taninos e fenóis, são bastante predadas pela larva Parapsis atomaria, atribuindo esse fato como 
diretamente ligado à disponibilidade de nitrogênio nas folhas.

Lightfoot \& Whitford (1987) encontraram uma 
Tab. 9 - Coeficientes de Correlação de Pearson (C) entre os parâmetros estudados e seus níveis descritivos de significância (p).

\begin{tabular}{lrlllllllllll}
\hline & \multicolumn{1}{c}{ Herbivoria } & \multicolumn{1}{c}{ Galhas } & \multicolumn{4}{c}{ Nitrogênio } & \multicolumn{2}{c}{ Tanino } & \multicolumn{2}{c}{ Fenóis } & \multicolumn{2}{c}{ Fibra } \\
\hline & $\mathrm{C}$ & $\mathrm{p}$ & $\mathrm{C}$ & $\mathrm{p}$ & $\mathrm{C}$ & $\mathrm{P}$ & $\mathrm{C}$ & $\mathrm{p}$ & $\mathrm{C}$ & $\mathrm{p}$ & $\mathrm{C}$ & $\mathrm{p}$ \\
Galha & 0,211 & 0,046 & & & & & & & & & & \\
Nitrogênio & 0,367 & 0,000 & 0,152 & 0,152 & & & & & & & & \\
Tanino & $-0,152$ & 0,097 & 0,193 & 0,069 & $-0,231$ & 0,011 & & & & & & \\
Fenóis & $-0,147$ & 0,108 & 0,294 & 0,005 & $-0,565$ & 0,000 & 0,327 & 0,000 & & & & \\
Fibra & 0,108 & 0,238 & $-0,014$ & 0,892 & 0,514 & 0,000 & $-0,212$ & 0,002 & $-0,475$ & 0,000 & & \\
Lignina & $-0,287$ & 0,001 & $-0,353$ & 0,001 & 0,070 & 0,419 & $-0,253$ & 0,005 & $-0,398$ & 0,000 & 0,342 & 0,000 \\
\hline
\end{tabular}


correlação positiva e significativa entre a produção de folhas, conteúdo de nitrogênio foliar e a densidade de artrópodes em Larrea tridentata, indicando o conteúdo de nitrogênio como importante fator regulador da quantidade de herbivoria sofrida por essa espécie.

Por outro lado, as concentrações de taninos, compostos fenólicos, fibras e ligninas tendem a minimizar a quantidade de herbivoria por reduzirem a eficiência digestiva do herbívoro (McKey et al., 1978; Reed, et al., 1982; Buchsbaum et al., 1984). Como exemplo, Tempel (1981) verificou uma correlação negativa significativa entre a concentração de taninos em Pteridium aquilinum e a quantidade de danos por herbivoria sofrida por essa espécie.

Separando-se os resultados por local de coleta obtiveram-se modelos de regressão diferentes explicando a quantidade de herbivoria foliar em cada local de amostragem (Tab. 10). Para a área do Rio Pilões, o parâmetro que melhor se relacionou com a quantidade de herbivoria foliar foi a quantidade de taninos. O coeficiente de explicação desse modelo é de 0,11 , indicando que $11 \%$ da variabilidade da porcentagem de herbivoria nesse local pode ser explicada pela quantidade de taninos foliares. Embora com coeficiente de explicação baixo, o coeficiente de regressão associado ao fator quantidade de taninos é significante. $\mathrm{Na}$ área do Rio Pilões, quanto maior a quantidade de taninos foliares menor foi a quantidade de herbivoria sofrida pelas folhas de Tibouchina pulchra.

Para o Caminho do Mar, o modelo de regressão que melhor explicou a quantidade de herbivoria foi o que relacionou a quantidade de ligninas foliares. Para essa área, houve uma diferença entre os valores de conteúdo de ligninas encontrados no primeiro e no segundo ano de coleta e, desta forma, o modelo selecionado deu origem a duas retas com a mesma inclinação, uma vez que apenas um fator foi selecionado, mas com magnitudes de herbivoria diferentes. $\mathrm{O}$ modelo encontrado para a área do Caminho do Mar possui um coeficiente de explicação de 0,248, podendo explicar aproximadamente $25 \%$ da intensidade de herbivoria. Nessa área, foi maior a intensidade de herbivoria foliar quanto menor a quantidade de ligninas presentes nas folhas de Tibouchina pulchra. 
No Vale do Mogi, um terceiro modelo foi selecionado, pelo qual a variável compostos fenólicos parece exercer maior influência na intensidade de herbivoria foliar. O coeficiente de explicação foi de apenas 0,08 , mas os testes de ajuste e de resíduos indicaram que esse modelo é bem ajustado aos dados obtidos, além de ser estatisticamente significante. Para a área do Vale do Mogi, aproximadamente $8 \%$ da intensidade de herbivoria pode ser explicada pela quantidade de compostos fenólicos, ou seja, a quantidade de herbivoria foliar foi tanto maior quanto menor a quantidade desses compostos nas folhas de Tibouchina pulchra.

Tab. 10 - Modelos selecionados a partir da análise de regressão de 40 observações para cada uma das sete variáveis explicativas em cada área amostrada. $\mathrm{RP}=$ Vale do Rio Pilões; $\mathrm{CM}=$ Caminho do Mar; $\mathrm{VM}=$ Vale do Rio Mogi; $\mathrm{H}=\%$ de herbivoria; $\mathrm{L}=\%$ de lignina; $\mathrm{T}=\%$ de taninos; $\mathrm{F}=\%$ compostos fenólicos.

\begin{tabular}{|c|c|c|c|}
\hline \multicolumn{2}{|c|}{ Área } & \multirow{2}{*}{$\begin{array}{l}\text { Equação de regressão } \\
\mathrm{H}=1,678-0,069 \mathrm{~T}\end{array}$} & \multirow{2}{*}{$\begin{array}{l}\text { Significância } \\
p=0,037\end{array}$} \\
\hline $\mathrm{RP}$ & & & \\
\hline $\mathrm{CM}$ & $\begin{array}{l}1996 \\
1997\end{array}$ & $\begin{array}{l}\mathrm{H}=2,31-0,106 \mathrm{~L} \\
\mathrm{H}=3,012-0,106 \mathrm{~L}\end{array}$ & $\begin{array}{l}p=0,003 \\
p=0,049\end{array}$ \\
\hline VM & & $\mathrm{H}=4,81-0,373 \mathrm{~F}$ & $\mathrm{p}=0,080$ \\
\hline
\end{tabular}

Os resultados da análise de regressão mostram respostas diferentes entre as duas áreas poluídas, Caminho do Mar e Vale do Rio Mogi, talvez por serem afetadas por diferentes tipos e concentrações de poluentes em cada área. Os modelos encontrados para explicar a intensidade de herbivoria sugerem que os parâmetros estudados neste trabalho não são os únicos a agirem, pois embora significantes estatisticamente, não explicam a maior parte da herbivoria sofrida, e portanto, outros fatores não avaliados neste trabalho devem estar atuando e interferindo na quantidade de herbivoria foliar sofrida pelos indivíduos das três áreas. 
No Caminho do Mar, há uma maior influência de poluentes secundários e poluentes orgânicos, assim como são maiores as concentrações foliares de nitrogênio, ligninas e fibras, e menores as concentrações de taninos e compostos fenólicos foliares em Tibouchina pulchra, havendo uma quantidade de área foliar perdida por herbivoria intermediária entre a encontrada para os indivíduos do Vale do Rio Mogi e do Rio Pilões. No Vale do Rio Mogi há maior influência de fluoretos, material particulado e compostos de enxofre e nitrogênio, encontrandose menores concentrações de compostos secundários, maior conteúdo de nitrogênio e maior quantidade de área foliar perdida por herbivoria. Embora aparentemente as duas áreas poluídas tenham apresentado comportamentos semelhantes em relação aos parâmetros estudados, através da análise de regressão pode-se verificar que o fator que melhor explica a quantidade de herbivoria é diferente para cada área, podendo indicar uma ação diferenciada da poluição atmosférica nos indivíduos de Tibouchina pulchra.

Os resultados obtidos apontam para uma tendência na ação da poluição em aumentar a palatabilidade/digestibilidade e a qualidade nutricional das folhas de Tibouchina pulchra, aumentando assim a intensidade herbivórica e a área foliar forrageada. Se considerarmos a afirmação de Harper (1990) de que a ação de herbívoros provoca um enfraquecimento da planta, uma vez que há maior perda de nutrientes e áreas fotossintetizantes, tornando a planta mais suscetível à ação de outros fatores de estresse, pode-se dizer que a herbivoria estaria tendo um efeito sinérgico com a poluição atmosférica, influenciando o estabelecimento e desenvolvimento das espécies vegetais nas áreas poluídas.

Tibouchina pulchra revelou-se uma espécie tolerante à ação da poluição, pois sofre alterações tanto químicas como bioquímicas e estruturais, como as verificadas neste trabalho e outros já realizados, mas apresenta-se amplamente distribuída em toda a região próxima ao complexo industrial de Cubatão, em vários estágios de desenvolvimento, indicando que consegue completar seu ciclo de vida. Exibindo nitidamente as alterações metabólicas que sofre em função da 
presença de poluentes atmosféricos no ambiente, pode-se considerar Tibouchina pulchra uma espécie potencialmente útil em programas de biomonitoramento nas áreas poluídas de Cubatão.

Os resultados mostraram que os parâmetros estudados podem ser utilizados como indicadores de estresse causado pela poluição aérea. Entretanto não foi possível relacioná-los à ação de um poluente em particular ou a concentrações específicas de determinados poluentes, uma vez que o estudo foi realizado em condições de campo. 


\section{CONCLUSÕES}

* Os indivíduos de Tibouchina pulchra das áreas poluídas do Caminho do Mar e Vale do Rio Mogi apresentaram em média maiores teores foliares de nitrogênio e menores de compostos fenólicos totais, taninos, ligninas e fibras, quando comparados com os indivíduos da área de referência no Vale do Rio Pilões. Para as concentrações médias dos teores estudados obteve-se: $\mathrm{VM}=\mathrm{CM}>\mathrm{RP}$ para os parâmetros nitrogênio e fibras; $\mathrm{RP}>\mathrm{VM}>\mathrm{CM}$ para compostos fenólicos e taninos; $\mathrm{CM}>\mathrm{RP}>\mathrm{VM}$ para ligninas. Observou-se maior porcentagem de área foliar perdida por herbivoria nos indivíduos do Vale do Mogi, seguidos pelos do Caminho do Mar e Rio Pilões. Essas alterações parecem estar relacionadas ao efeito da poluição aérea local.

* Houve maior ocorrência de galhas nas folhas dos indivíduos da área do Vale do Rio Mogi, uma ocorrência intermediária no Vale do Rio Pilões e menor ocorrência no Caminho do Mar. A presença de maiores concentrações de lignina nas folhas dos indivíduos do Caminho do Mar, quando comparados com os das duas outras áreas, talvez possa explicar a menor incidência de galhas nesse local.

* Na área de referência do Vale do Rio Pilões, o fator que mais influenciou na intensidade de herbivoria foliar foi a concentração de taninos, ou seja, quanto maior o conteúdo de taninos foliares, menor foi a quantidade de área foliar perdida por herbivoria.

* No Caminho do Mar, o fator mais importante foi a quantidade de lignina foliar, observando-se herbivoria mais intensa quanto menor a quantidade de lignina.

* No Vale do Rio Mogi, a intensidade de herbivoria foliar foi melhor explicada pelo teor de compostos fenólicos totais. Quanto menor a quantidade de compostos fenólicos, maior a quantidade de área foliar perdida por herbivoria. 
* Os modelos encontrados para explicar a intensidade de herbivoria sugerem que os parâmetros estudados neste trabalho não são os únicos a agir, pois embora significantes estatisticamente, não explicam a maior parte da herbivoria observada. Portanto, outros fatores, não avaliados neste trabalho, devem estar atuando e interferindo na intensidade de herbivoria foliar sofrida pelos indivíduos das três áreas.

* A herbivoria foliar pode ter um efeito sinérgico com a poluição atmosférica e funcionar como mais um fator de estresse para as espécies das florestas das áreas poluídas do Vale do Mogi e Caminho do Mar, uma vez que pode agravar o enfraquecimento da planta, devido à retirada de nutrientes e de áreas verdes fotossintetizantes nos indivíduos das áreas poluídas. 


\section{REFERÊNCIAS BIBLIOGRÁFICAS}

AIDE, T.M. \& ZIMMERMAN, J.K. 1990. Patterns of insect herbivory, growth and survivorship in juveniles of a neotropical liana. Ecology 71 (4): 1412-1421.

ALONSO, C.D. \& GODINHO, R. 1992. A evolução da qualidade do ar em Cubatão. Química Nova 15 (2): 126-138.

ALSTAD, D.N.; EDMUNDS, G.F. \& WEINSTEIN, L.H. 1982. Effects of air pollutants on insect populations. Annual Review of Entomology 27: 369-384.

ANDERSON, L.E.; MUSCHINEK, G. \& MARQUES, I. 1987. Effects of $\mathrm{SO}_{2}$ and sulfite on stromal metabolism. IN: Air pollution and plant metabolism (Schulte-Hostedes et al., eds.). Elsevier Applied Science, London, New York, p.134-147.

APPEL, H.M. 1993. Phenolics in ecological interactions; the importance of oxidation. Journal of Chemical Ecology 19 (7): 15211552.

ARNDT, U. \& SCHWEIZER, B. 1991. The use of bioindicators for environmental monitoring in tropical and subtropical countries. IN: Biological monitoring - signals from the environment (Ellenberg, $\mathrm{H}$. et al., eds.). Vieweg, Eschbotin, p. 199-259.

AZEVEDO, C.M.A.; POMPÉIA, S.L.; FIALHO, R.C. \& MENDONÇA, R.R. 1994. O efeito agudo da amônia sobre a Mata Atlântica. Ambiente 8 (1): 21-25.

BATAGLIA, O.C.; FURLANI, A.M.C.; TEIXEIRA, J.P.F., FURLANI, P.R.; GALLO, J.R. 1983. Métodos de análise química de plantas. Boletim técnico $\mathrm{n}^{\mathrm{O}}$ 78. Instituto Agronômico, Campinas, São Paulo.

BASSET, V. 1991. The spatial distribution of herbivory, mines and galls within an australian rain forest tree. Biotropica 23 (3): 271-281.

BEART, J.E.; TERENCE, H.L. \& HASLAM, E. 1985. Plant polyphenols secondary metabolism and chemical defense: some observations. Phytochemistry 24 (1): 33-38.

BELL, E.A. 1980. The possible significance of secondary compounds in plants. IN: Secondary plant products (Bell, E.A. \& Charlwodd, B.V. eds.). Encyclopedia of plant physiology, New Series vol. 8. SpringVerlag, Berlim, p. 11-21.

BENNET, N. \& WALLSGROVE R.M. 1994. Secondary metabolism in plant defense mechanisms. New Phytologist 127: 617-633. 
BRAGANÇA, E.F.; KONO, E.C.; AGUIAR, L.S.J. \& SANTOS, R.P. 1987. Avaliação da degradação da Serra do Mar. Ambiente 1 (2): 77-85.

BUCHSBAUM, R.; VALIELA, I. \& SWAIN, T. 1984. The role of phenolic compounds and other plant constituents in feeding by canada geese in a coastal marsh. Oecologia 63: 343-349.

CÂMARA, I.G. 1991. Conservação da Mata Atlântica. pp. 161-188. IN: Mata Atlântica (Câmara, I.G., ed.). Index e Fundação SOS Mata Atlântica, São Paulo.

CERSÓSIMO, L.F. 1993. Variações espaciais e temporais no estabelecimento de plântulas em trecho de floresta secundária em São Paulo, SP. Dissertação de Mestrado, Universidade de São Paulo, São Paulo.

CETESB - COMPANHIA DE TECNOLOGIA DE SANEAMENTO AMBIENTAL 1984. A degradação da vegetação da Serra do Mar em Cubatão. Relatório preliminar. CETESB, São Paulo.

CETESB - COMPANHIA DE TECNOLOGIA DE SANEAMENTO AMBIENTAL 1991. Avaliação do estado de degradação dos ecossistemas da Baixada Santista - SP. Relatório Técnico. CETESB, São Paulo.

CETESB - COMPANHIA DE TECNOLOGIA DE SANEAMENTO AMBIENTAL 1992. Ações da CETESB em Cubatão. Relatório Técnico. Situação em Junho de 1992. CETESB, São Paulo.

CETESB - COMPANHIA DE TECNOLOGIA DE SANEAMENTO AMBIENTAL 1995. Composição florística e estrutura da mata Atlântica afetada pela poluição em Cubatão - SP. Relatório Técnico, outubro 1995. CETESB, São Paulo.

CETESB - COMPANHIA DE TECNOLOGIA DE SANEAMENTO AMBIENTAL 1997. Relatório Anual de Qualidade do Ar: Relatório de Qualidade do ar no Estado de São Paulo 1997. Série Relatórios, CETESB, São Paulo.

COBB, F.W.; ZAVARIN, E. \& BERGOT, J. 1972. Effect of air pollution on the volatile oil from leaves of Pinus ponderosa. Phytochemical 11: $1815-1818$.

COLEY, P.D. 1983. Herbivory and defensive characteristics of tree species in a lowland tropical forest. Ecological Monographs 53: 209-233.

COLEY, P.D. 1986. Costs and benefits of defense by tannins in a neotropical tree. Oecologia 70: 238-241. 
COLEY, P.D. \& AIDE, T.M. 1991. Comparison of herbivory and plant defenses in temperate and tropical broad-leaved forests. IN: Plantanimal interactions. Evolutionary Ecology in tropical and temperate regions (Price et al., eds.). John Wiley \& Sons, New York, p. 25-49.

COLEY, P.D; BRYANT, J.P. \& CHAPIN III, F.C. 1985. Resource availability and plant antiherbivore defense. Science 230: 895-899.

DARRALL, N.M. 1989. The effect of air pollutants on physiological processes in plants. Plant, Cell and Environment 12 (1): 130 .

DÄSSLER, H.G. \& BÖRTITZ, S. 1988. Air pollution and its influence on vegetation. T:VS 18 (Tasks for vegetation science $\mathrm{n}^{\circ}$. 18). Dr. W. Junk publishers.

DENCE, C.W. \& LIN, S.Y. 1992. I. Introduction. IN: Methods in lignin chemistry (Lin, S.Y. \& Dence, C.W., eds.). Springer-Verlag, Berlim, p. 3-19.

DINIZ, K.M.; MARQUEZ, U.M.L.; BARROS, R.M.C. \& POMPÉIA, S.L. 1994. Composição de aminoácidos livres em plantas da Mata Atlântica sob estresse provocado por poluentes atmosféricos em Cubatão, SP. X Congresso da Sociedade de Botânica de São Paulo, Santos, Brasil, 4-10 set/1994. Resumos p. 87.

DOMINGOS, M 1998. Biomonitoramento da fitotoxicidade da poluição aérea e da contaminação do solo na região do complexo industrial de Cubatão, São Paulo, utilizando Tibouchina pulchra Cogn. como espécie indicadora. Tese de doutorado, Universidade de São Paulo, São Paulo.

DOMINGOS, M.; KLUMPP, G. \& KLUMPP, A. 1993. Passive biomonitoring. IN: Air pollution and vegetation damage in the tropics: The Serra do Mar as an example. (Guderian, R. \& De Vuono, Y.S., coord.).Vegetation Module, Final Report 1989-1993.

EHRLICH, P. \& RAVEN, P.H. 1964. Butterflies and plants: study in coevolution. Evolution 18: 586-608.

ELLENBERG, H. 1991. Bioindicators and biological monitoring. IN: Biological monitoring - signals from the environment (Ellenberg et al., eds.). Vieweg, Eschbotin, p. 13-74.

ESTIARTE, M.; FILELLA, I.; SERRA, J. \& PEÑUELAS, J. 1994. Effects of nutrient and water stress on leaf phenolic content of peppers and 
susceptibility to generalist herbivore Helicoverpa armigera (Hubner). Oecologia 99: 387-391.

FIALHO, R.C. 1998. Acumulação foliar de fluoretos e seu significado ecológico em espécies arbórias da Mata Atlântica, Cubatão, São Paulo. Dissertação de Mestrado, Universidade de São Paulo, São Paulo.

FIALHO, R.C.; AZEVEDO, C.M.A.; PELAES, K.B. \& POMPÉIA, S.L. 1994. Aspectos anatômicos e fisiológicos e a acumulação foliar de poluentes atmosféricos em espécies da Mata Atlântica de Cubatão, SP. X Congresso da Sociedade de Botânica de São Paulo, Santos, Brasil, 4-10 set/1994. Resumos p. 86.

FIALHO, R.C. \& BÜCKER, J. 1996. Changes in levels of foliar carbohydrates and myo-inositol before premature leaf senescence of Populus nigra induced by a mixture of $\mathrm{O}_{3}$ and $\mathrm{SO}_{2}$. Canadian Journal Of Botany 74 (6): 965-970.

FIEDLER, F. \& MASSAMBANI, O.(resp.) 1997. Circulation and mass transport module. IN: Air pollution and vegetation damage in the tropics - The Serra do Mar as an example - Final Report 1990-1996 (Klockow, et al., eds.) German/Brazilian Cooperation in Environmental Research and Technology, SHIFT (Studies on Human Impact on Forest and Floodplains in the Tropics) Program. GKSS Forschungszentrum Geesthacht $\mathrm{GmbH}$, Geesthacht.

FLORES, F.E.V. 1987. O uso de plantas como bioindicadores de poluição no ambiente urbano industrial: experiências em Porto Alegre, RS, Brasil. Tübinger Geographische Studen 96: 79-86.

FLÜCKIGER, W.; BRAUN, S. \& BOLSINGER, M. 1987. Air pollution: effect on hostplant-insect interactions. IN: Air pollution and plant metabolism (Schulte-Hostede et al., eds.). Elsevier Applied Science, London, New York, p. 366-381.

FOLIN, O. \& CIOCALTEU, V. 1927. On tyrosine and tryptophane determination in proteins. Journal of Biological Chemistry. 27: 627650.

FOLIN, O. \& DENIS, W. 1912. Tyrosine in proteins as determined by a new colorimetric method. Journal of Biological Chemistry 12: 245251.

FOX, L.R. \& MACAULEY, B.J. 1977. Insect grazing on eucalyptus in response to variation in leaf tannins and nitrogen. Oecologia 29: 145162. 
FREEDMAN, B. 1989. Environmental ecology: the impacts of pollution and other stresses on ecosystem structure and function. Academic Press Inc., New York.

FURLAN, C.M.; KLUMPP, G. \& DOMINGOS, M. 1995. Ascorbic acid contents and peroxidase activity in Tibouchina pulchra and

Cryptocarya sp. saplings exposed to air pollution at the Serra do Mar near Cubatão. $2^{\text {nd }}$ SHIFT-Workshop, Cuiabá, Brasil, 10-14 jul/1995. Summaries p. 59.

GALVÃO FILHO, J.B. 1988. Controle da poluição ambiental: Cubatão, filosofia e conceito. Ambiente 2: 70-73.

GUDERIAN, R.; TINGEY, D.T. \& RABE, R. 1985. Effects of photochemical oxidants on plants. IN: Air pollution by photochemical oxidants: formation, tranport, control and effects on plants (Guderian, R., ed.). Ecological Studies 52, Springer-Verlag, Berlim.

GUTBERLET, J. 1996. Cubatão: desenvolvimento, exclusão social e degradação ambiental. Edusp, São Paulo.

HAGERMAN, A.E. 1987. Radial diffusion method for determining tannin in plant extracts. Journal of Chemical Ecology 13 (3): 437-449.

HAGERMAN, A.E. \& BUTLER, L.G. 1989. Choosing appropriate methods and standards for assaying tannin. Journal of Chemical Ecology 15 (6): 1795-1810.

HANOVER, J.W. 1975. Physiology of tree resistance to insects. Annual Review of Entomology 20: 75-95.

HARBORNE, J.B. 1980. Plant Phenolics. IN: Secondary plant products. (Bell, E.A. \& Charlwood, B.V., eds.). Encyclopedia of plant physiology, New Series vol. 8. Springer-Verlag, Berlim, p. 329-402.

HARBORNE, J.B. 1982. Introduction to ecological biochemistry. Academic Press, New York.

HARBORNE, J.B. 1984. Phytochemical methods: a guide to a modern techniques of plant analysis. Chapman \& Hall, London.

HARBORNE, J.B. 1987. Chemical Signals in the ecosystem. Annals of Botany 60 (4): 39-57.

HARBORNE, J.B. 1988. The flavonoids: recent advances. pp. 299-343. IN: Plant pigments (Goodwin, T.W., ed.). Academic Press, London.

HARPER, J.L. 1990. Population biology of plants. Academic Press Inc., San Diego.

HATFIELD, R.D.; JUNG, H.J.; RALPH , J.; BUXTON, D.R. \& WEINER, P.J. 1994. A comparison of the insoluble residues produced by the 
klason lignin and acid detergent lignin procedures. Journal of the Science and Food Agriculture 65: 51-58.

HAUTALA, E.L. \& HOLOPAINEN, J.K. 1995. Gramine and free amino acids as indicators of fluoride-induced stress in Barley and its consequences to insect herbivory. Ecotoxicology and Environmental Safety 31: 238-245.

HEAGLE, A. S. 1973. Interactions between air pollutants and plant parasites. Annual Review of Phytopathology 11: 365-388.

HERRMANN, K.M. 1995. The shikimate pathway as an entry to aromatic secondary metabolism. Plant Physiology 107 (1): 7-12.

HIGUCHI, T. 1981. Biosynthesis of Lignin. IN: Plant carbohydrates II: extracellular carbohydrates. Encyclopedia of plant physiology, New Series vol. 13B (Tanner, W. \& Loewus, F.A., eds.). Springer-Verlag, Berlim, p. 194-224.

HUGHES, P.R. 1988. Insect populations on host plants subjected to air pollution. IN: Plant stress-insect interactions (Heinrichs, E.A., ed.). Environmental Science and Technology, John Wiley \& Sons, New York, p. 249-319.

HUNTLY, N. 1991. Herbivores and the dynamics of communities and ecosystems. Annual Review of Ecological Systems 22: 477-503.

HUTTUNEN, S. 1984. Interactions of disease and other stress factors with atmospheric pollution. IN: Air pollution and plant life (Treshow, M., ed.). John Wiley \& Sons, p. 321-356.

IQBAL, M.; ABDIN, M.Z.; MAHMOODUZZAFAR, M.; YUNUS, M. \& AGRAWAL, M. 1996. Resistance mechanisms in plants against air pollution. IN: Plant response to air pollution (Yunus, M. \& Iqbal, M., eds.). John Wiley \& Sons, Chichester, p. 195-240.

JAESCHKE, W. 1997. Chemistry module. IN: Air pollution and vegetation damage in the tropics - The Serra do Mar as an example - Final Report 1990-1996 (Klockow, et al., eds.) German/Brazilian Cooperation in Environmental Research and Technology, SHIFT (Studies on Human Impact on Forest and Floodplains in the Tropics) Program. GKSS - Forschungszentrum Geesthacht GmbH, Geesthacht. JÄGER, H.J. 1982. Biochemical indication of an effect of air pollution on plants. IN: Monitoring of air pollution by plants: methods and problems (Jäger, H.J. \& Steubing, L., eds.). International Workshop, Osna Brück, RFA, p. 99-108. 
JONES, C.G. \& COLEMAN, J.S. 1991. Plant stress and insect herbivory: toward an integrated perspective. IN: Responses of plant to multiple stresses (Mooney et al., eds.). Academic Press, London, p. 249-282.

KAINULAINEN, P.; HOLOPAINEN, J.K.; HYTTINEN, H. \& OKSANEN, J. 1994. Effect of ozone on the biochemistry and aphid infestation of Scots pine. Phytochemistry 35 (1): 39-42.

KAINULAINEN, P.; HOLOPAINEN, J.K. \& OKSANEN, J. 1995. Effects of $\mathrm{SO}_{2}$ on the concentrations of carbohydrates and secondary compounds in Scots pine (Pinus sylvestris L.) and Norway spruce (Picea abies (L.) Karst.) seedlings. New Phytologist 130 (2): 231-238.

KARBAN, R. 1990. Herbivore outbreaks on only young trees: testing hypotheses about aging and induced resistance. Oikos 59 (1): 27-32. KATOH, T.; KASUYA, M.; KAGAMIMORI, S.; KOZUKA, H. \& KAWANO, S. 1989a. Inhibition of the shikimate pathway in the leaves of vascular plants exposed to air pollution. New Phytologist 112 (3): 363-367.

KATOH, T.; KASUYA, M.; KAGAMIMORI, S.; KOZUKA, H. \& KAWANO, S. 1989b. Effects of air pollution on tannin biosynthesis and predation damage in Cryptomeria japonica. Phytochemistry $\mathbf{2 8}$ (2): 439-445.

KICINSKI, H.G.; KETTRUP, A.; BOOS, K.S. \& MASUCH, G. 1988. Single and combined effects of continuous and discontinuous $\mathrm{O}_{3}$ and $\mathrm{SO}_{2}$ emission on Norway Spruce needles: II. Metabolic changes. International Journal of Environmental Analytical Chemistry 32: 214241.

KLUMPP, A.; KLUMPP, G. \& DOMINGOS, M. 1994a. Plants as biomonitors of air pollution at the Serra do mar near the industrial complex of Cubatão, Brazil, Environmental Pollution 85: 109-116.

KLUMPP, A.; DOMINGOS, M.; MODESTO, I.F. \& SILVA, M.D. 1994b. Tibouchina pulchra as accumulative indicator of fluoride pollution at the Serra do Mar near Cubatão, SP. II Congresso de Ecologia do Brasil, Londrina, Brasil, 5-9 dec./1994. Resumos, vol. 2, p. 602.

KLUMPP, A.; KLUMPP, G. \& DOMINGOS, M. 1996. Bioindicators of air pollution in the tropics: the active monitoring program near Cubatão (Brasil). Gefahrstroffe-Reinhaltung der Luft Bd. 56: 27-31. 
KLUMPP, A.; DOMINGOS, M.; KLUMPP, G. \& GUDERIAN, R. 1997 Vegetation Module. IN: Air pollution and vegetation damage in the tropics - The Serra do Mar as an example - Final Report 1990-1996 (Klockow, et al., eds.) German/Brazilian Cooperation in Environmental Research and Technology, SHIFT (Studies on Human Impact on Forest and Floodplains in the Tropics) Program. GKSS Forschungszentrum Geesthacht $\mathrm{GmbH}$, Geesthacht.

LEA, P.J.; ROWLAND-BAMFORD, A.J. \& WOLFENDEN, J. 1996. The effect of air pollutants and elevated carbon dioxide on nitrogen metabolism. IN: Plant response to air pollution (Yunus, M. \& Iqbal, M., eds.). John Wiley \& Sons, Chichester, p. 319-352.

LEITÃO FILHO, H.F. (org.) 1993. Ecologia da Mata Atlântica em Cubatão (SP). UNESP, São Paulo.

LIGHTFOOT, D.C. \& WHITFORD, W.G. 1987. Variation in insect densities on desert creosotebush: is nitrogen a factor? Ecology 68 (3): 547-557.

LOUDA, S.M. \& COLLINGE, S.K. 1992. Plant resistance to insect herbivores: a field test of the environmental stress hypothesis. Ecology 73 (1): 153-169.

MAKKAR, H.P.S. \& SINGH, B. 1991. Effect of drying conditions on tannin, fiber and lignin levels in mature oak (Quercus incana) leaves. Journal of the Science and Food Agriculture 54: 323-328.

MALHOTRA, S.S. \& KHAN, A. A. 1984. Biochemical and physiological impact of major pollutants. IN: Air pollution and plant life (Treshow, M., ed.). John Wiley \& Sons, p. 113-157.

MANN, J. 1987. Secondary metabolism. Oxford Chemistry series 33. Oxford University Press, Oxford.

MATTSON, W.J. 1980. Herbivory in relation to plant nitrogen content. Annual Review of Ecological System 11: 119-161.

MAYER, R. \& LOPES, M.I.M.S. 1997. Soil module. IN: Air pollution and vegetation damage in the tropics - The Serra do Mar as an example Final Report 1990-1996 (Klockow, et al., eds.) German/Brazilian Cooperation in Environmental Research and Technology, SHIFT (Studies on Human Impact on Forest and Floodplains in the Tropics) Program. GKSS - Forschungszentrum Geesthacht GmbH, Geesthacht. MAZZONI-VIVEIROS, S.C. 1996. Aspectos estruturais de Tibouchina pulchra Cogn. (Melastomataceae) sob o impacto de poluentes 
atmosféricos provenientes do complexo industrial de Cubatão, SPBrasil. Tese de doutorado, Universidade de São Paulo, São Paulo. McKEY, D.; WATERMAN, P.G.; MBI, C.N.; GARTLAN, J.S. \& STRUHSAKER, T.T. 1978. Phenolic content of vegetation in two african forests: ecological implications. Science 202: 61-64.

McNAUGHTON, S.J. 1983. Physiological and ecological implications of herbivory. IN: Physiological plant ecology III: responses to the chemical and biological environment (Lange et al., eds.). Encyclopedia of plant physiology, vol. 12c. Spring-Verlag, Berlim, p. 657-677.

MIGUEL, A H. 1992. Poluição atmosférica urbana no Brasil: uma visão geral. Química Nova 15 (2): 118-125.

MODESTO, I.F., DOMINGOS, M. \& KLUMPP, A. 1996. Alterações em parâmetros de crescimento em Tibouchina pulchra Cogn. Cultivadas em solos com níveis diferentes de contaminação, provenientes da região da Serra do Mar, Cubatão - SP. III Congresso de Ecologia do Brasil, Brasília, Brasil, 6-11 out/1996. Resumos, p. 293.

MOLE, S. \& WATERMAN, P.G. 1987. A critical analysis of techniques for measuring tannins in ecological studies. I. Techniques for chemically defining tannins. Oecologia 72: 137-147.

MUDD, J.B. \& KOZLOWSKI, T.T.1975. Responses of plants to air pollution. Physiological Ecology Series, Academic Press, New York.

NEISH, A.C. 1965. Coumarins, phenylpropanes and lignin. IN: Plant Biochemistry (Bonner, J. \& Varner, J.E., eds.). Academic Press, New York, p. 581-615.

NETER, J.; KUTNER, M.H.; NACHTSHEIM, C.J. \& WASSERMAN, W. 1996. Applied linear statistical models. Truvim, Chicago.

NORRIS, D.M. 1988. Sesitivity of insect-damaged plants to environmental stresses. IN: Plant stress-insect interations (Heirichs, E.A., ed.). Environmental Science and Technology, John Wiley \& Sons, NY, p. 341-361.

PEARSON, J. \& STEWART, G.R. 1993. The deposition of atmospheric ammonia and its effects on plants. New Phytologist 125: 283-305.

PELL, E.F. 1987. Secondary metabolism and air pollutants. IN: Air pollution and plant metabolism (Schulte-Hostede et al., eds.). Elsevier Applied Science, London, New York, p 222-237. 
PHILLIPS, R. \& HENSHAW, G.G. 1977. The regulation of synthesis of phenolics in stationary phase cell cultures of Acer pseudoplatanus L. Journal of Experimental Botany 28 (105): 785-794.

POBORSKI, P.S. 1987. Pollutant penetration through the cuticle. IN: Air pollution and plant metabolism (Schulte-Hostede et al., eds.). Elsevier Applied Science, London, New York, p 91-35.

POMPÉIA, S.L. 1997. Sucessão secundária da Mata Atlântica em áreas afetadas pela poluição atmosférica de Cubatão, SP. Tese de Doutorado, Universidade de São Paulo, São Paulo.

POMPÉIA, S.L.; PRADELLA, D.Z.A.; MARTINS, S.E.; SANTOS, R.C. \& DINIZ, K.M. 1989. A semeadura aérea na Serra do Mar em Cubatão. Ambiente 3 (1): 13-19.

PRADELLA, D.Z.A 1997. Estudos com Tibouchina pulchra Cogn. (Melastomataceae) - (Manacá da Serra) submetida a estresse por poluição na Serra do Mar em Cubatão - SP - Brasil. Dissertação de mestrado, Universidade Federal de São Carlos, São Paulo.

PRASAD, B.J. \& RAO, D.N. 1985. Phytomonitoring of air pollution in the vicinity of a petroleum refinery. Environmental Conservation 12 (4): 351-354.

PRICE, P.W. 1991. The plant vigor hypothesis and herbivore attack. Oikos 62: 244-251.

PRINS, A.H. \& NELL, H.W. 1990. Positive and negative effects of herbivory on the population dynamics of Senecio jacobaea L. and Cynoglossum officinale L. Oecologia 83: 325-332.

REED, J.D.; McDOWELL, R.E.; VAN SOEST, P.J. \& HORVATH, P.J. 1982. Condensed tannins: a factor limiting the use of Cassava forage. Journal of the Science and Food Agriculture. 33: 213-220.

ROWLAND, A.J.; MURRAY, A.J.S. \& WELLBURN, A.R. 1985. Oxides of nitrogen and this impact upon vegetation. Reviews on Environmental Health 5 (4)

ROWLAND, A.J.; DREW, M.C. \& WELLBURN, A.R. 1987a. Foliar entry and incorporation of atmospheric nitrogen dioxide into barley plants of different nitrogen status. New Phytologist 107: 357-371.

ROWLAND, A.J.; BORLAND, A.M. \& LEA, P.J. 1987b. Changes in amino-acids, amines and proteins in response to air pollutants. IN: Air pollution and plant metabolism (Schulte-Hostede et al., eds.). Elsevier Applied Science, London, New York, p 189-222. 
SCHLESINGER, W.H. 1991. Biogeochemistry: an analysis of global change. Academic press, New York.

SCHWEIZER, T. \& WÜRSCH, P. 1979. Analysis of dietary fiber. Journal of the Science and Food Agriculture 30: 613-619.

SEIGLER, D.S. 1977. Primary roles for secondary compounds. Biochemical Systematic and Ecology 5: 195-199.

SELVENDRAN, R.R; VERNE, A.V.F.V. \& FAULKS, R.M. 1989.

Methods for analysis of dietary fiber. IN: Plant Fibers (Linskens, H.F. \& Jackson, J.F., eds.). Modern methods of plant analysis, New Series vol. 10. Springer-Verlag, Berlim, p. 234-259.

SHEU, B.H. 1994. Effects of sulfur dioxide on growth, photosynthesis and enzyme activities of chinese guger-tree seedlings. Environmental Pollution 86: 349-354.

SMA - SECRETARIA DO MEIO AMBIENTE 1990. A Serra do mar: degradação e recuperação. Série documentos - Secretaria do Meio Ambiente, Instituto de Botânica, Instituto Florestal, Companhia de Tecnologia de Saneamento Ambiental, São Paulo.

SMA - SECRETARIA DO MEIO AMBIENTE 1993. Poluição atmosférica e danos à vegetação nos trópicos - A Serra do mar como um exemplo. Projeto ENV-3 SMA/GKSS-RFA.

SMIRNOFF, N.; TODD, P. \& STEWART, G.R. 1984. The occurrence of nitrate reduction in the leaves of woody plants. Annals of botany $\mathbf{5 3}$ : 363-374.

STRERCK, F.; VAN DER MEER, P. \& BONGERS, F. 1992. Herbivory in two rainforest canopies en French Guyana. Biotropica 24 (1): 97-99.

STEUBING, L. \& FANGMEIER, A. 1991. Gaseous air pollutants and forest floor vegetation - a case study at different levels of integration. IN: Modern ecology: basic and applied aspects (Esser, G. \& Overdieck, D., eds.). Elsevier, Amsterdam, p. 539-569.

SUMMERS, C.B. \& FELTON, G.W. 1994. Prooxidant effects of phenolic acids on the generalist herbivore HELICOVERPA ZEA (Lepidoptera : Noctuidae): potential mode of action for phenolic compounds in plant anti-herbivore chemistry. Insect Biochemistry and Molecular Biology 24 (9): 943-953

SWAIN, T. 1979. Tannins and lignins. IN: Herbivores: their interaction with secondary plant metabolism (Rosenthal, G.A. \& Janzen, D.H., eds.). Academic Press, New York, pp. 657-682. 
TARGA, H.J. \& KLOCKOW, D. 1997. Introduction. IN: Air pollution and vegetation damage in the tropics - The Serra do Mar as an example Final Report 1990-1996 (Klockow, et al., eds.) German/Brazilian Cooperation in Environmental Research and Technology, SHIFT (Studies on Human Impact on Forest and Floodplains in the Tropics) Program. GKSS - Forschungszentrum Geesthacht GmbH, Geesthacht. TEMPEL, A.S. 1981. Field studies of the relationship between herbivore damage and tannin concentration in Bracken (Pteridium aquilinum Kuhn). Oecologia 51: 97-106.

TRESHOW, M. 1975. Interaction of air pollutants and plant diseases. IN: Response of plants to air pollution (Mudd, J.B. \& Kozlowski, T.T., eds.). Academic Press, New York, p. 307-334

TRESHOW, M. \& ANDERSON, F. 1989. Plant stress from air pollution. Physiological Ecology Series. John Wiley \& Sons, New York.

TROPPMAIR, H. \& FERREIRA, M.E.M.C. 1987. Cobertura Vegetal, poluição aérea e deslizamento na Serra do Mar. Geografia, 12 (23): 117-129.

VAN SOEST, P.J. 1963. Use of detergents in the analysis of fibrous feeds. II. A rapid method for the determination of fiber and lignin. Journal of the AOAC 46 (5): 829-835.

VASCONCELOS, N.V. \& ABREU, R.M. 1987. Situação do controle da poluição em Cubatão. Ambiente 1 (3): 128-131.

WATERMAN, P.G. \& MOLE, S. 1994. Analysis of phenolic plant metabolites. Blackwell Scientific publications, Oxford.

WEIGEL, H.J.; HALBWACHS, G. \& JÄGER, H.J. 1989. The effects of air pollutants on forest trees from a plant physiological view. Journal of Plant Diseases and Protection 96 (2): 203-217.

WHITTAKER, R.H \& FEENY, P.P. 1971. Allelochemics: chemical interactions between species. Science 171: 757-770.

YOSHIDA, T. \& KUWANO, K. 1989. Methods used in the investigation of insoluble dietary fiber. IN: Plant Fibers (Linskens, H.F. \& Jackson, J.F., eds.). Modern Methods of plant analysis, New Series vol. 10. Springer-Verlag, Berlim, p. 260-277. 